\title{
Versatile synthesis of novel tetrahydroquinolines as potentially active semicarbazide-sensitive amine oxidase (SSAO) inhibitors via tert-amino effect
}

\author{
Ruth Deme, ${ }^{\mathrm{a}}$ Michele Schlich, ${ }^{\mathrm{b}}$ Zoltán Mucsi, ${ }^{\mathrm{c}}$ Gellért Karvaly, ${ }^{\mathrm{d}}$ Gergö Tóth, ${ }^{\mathrm{e}}$ \\ and Péter Mátyus*a \\ ${ }^{a}$ Department of Organic Chemistry, Semmelweis University, Högyes E. u. 7., H-1092 \\ Budapest, Hungary \\ ${ }^{b}$ Department of Life and Environmental Sciences, University of Cagliari, Via Ospedale 72, \\ 09124 Cagliari, Italy \\ ${ }^{c}$ Femtonics Ltd., Tüzoltó u. 59., H-1094, Budapest, Hungary \\ ${ }^{d}$ Department of Laboratory Medicine, Semmelweis University, Szentkirályi u. 46., H-1088 \\ Budapest, Hungary \\ ${ }^{e}$ Department of Pharmaceutical Chemistry, Semmelweis University, Högyes E. u. 9., H-1092 \\ Budapest, Hungary \\ E-mail: matyus.peter@pharma.semmelweis-univ.hu
}

DOI: http://dx.doi.org/10.3998/ark.5550190.p009.692

\begin{abstract}
Several aminomethyl tetrahydroquinoline derivatives were synthesized in a facile three-step procedure, in order to develop a semicarbazide-sensitive amine oxidase (SSAO) inhibitor library, as proved by in vitro test on rat aorta microsomal fraction. The efficient microwave-assisted cisdiastereoselective cyclization of 2-dicyanovinyl-tert-anilines is based on tert-amino effect as a thermal isomerization reaction. The cyclized dicarbonitrile intermediates were subjected to a decyanation reaction and a subsequent reduction, providing the biologically active aminomethyl tetrahydroquinoline derivatives.
\end{abstract}

Keywords: Diastereoselective cyclization, microwave-assisted reaction, SSAO activity, tetrahydroquinolines, tert-amino effect

\section{Introduction}

Semicarbazide-sensitive amine oxidase (SSAO), also known as vascular adhesion protein-1 (VAP-

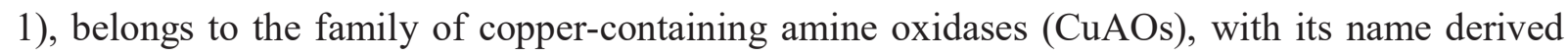
from its sensitivity to inhibition by the semicarbazide. ${ }^{1} \mathrm{SSAO}$ is identical to primary amine oxidase $(\mathrm{SSAO} / \mathrm{PrAO}),{ }^{2}$ as well as circulating benzylamine amine oxidase $(\mathrm{BzAO}){ }^{3}$ The oxidative 
deamination of primary aliphatic and aromatic amines, results in a corresponding aldehyde metabolite, hydrogen peroxide and ammonia. The pharmacological significance of SSAO/VAP-1 inhibitors are demonstrated by several studies: pathological angiogenesis, ${ }^{4}$ ocular diseases, ${ }^{5-7}$ neuroprotective effect ${ }^{8-10}$ and anti-inflammatory effect. ${ }^{11-14}$ Furtheremore, SSAO substrates might also be of therapeutic value in the treatment of diabetes due to their insulin-like effects (e.g., glucose uptake, lipogenesis stimulation and antilipolysis). Therefore, several potent substrates were investigated in human adipocytes compared with benzylamine as the reference substrate. ${ }^{15,16}$

Recently, new therapeutic aspects of SSAO inhibitors have been published associated with preventing the progress of cerebral amyloid angiopathy in Alzheimer's disease; ${ }^{17}$ analgesic effects in traumatic neuropathy and neurogenic inflammation ${ }^{18}$ and expression of glucose transporters in chronic liver disease. ${ }^{19}$ Furtheremore, the role of SSAO/VAP-1 in physiopathology of several diseases and application as a biomarker ${ }^{20}$ have been highlighted as well (e.g. ischemic stroke, ${ }^{21}$ renal dysfunction and vascular inflammation in type 1 diabetes ${ }^{22}$ ). In addition to, new therapeutic targets were reported by Payrits et al. namely, they have described a dual antagonistic action of a known SSAO inhibitor on transient receptor potential ankyrin 1 and vanilloid 1 ion channels on primary sensory neurons. ${ }^{23}$ In order to understand the role of substrate and inhibitor selectivity and efficacy in CuAOs, Shepard and Dooley have summarized the factors which may play the role of these. This study has presented the significance of copper in the biogenesis of topaquinone and in the catalytic cycle as well. ${ }^{24}$ Regarding the importance of the field of SSAO in our days, the phase 1 clinical trial of PXS-4728A should be mentioned as well, which is a very potent and selective inhibitor for the treatment of liver-related disease Nonalcoholic Steatohepatitis (NASH) ${ }^{14}$ Until now, only few reversible inhibitors of that enzyme were reported in the literature, ${ }^{25-27}$ however, none of them based on tetrahydroquinoline scaffold. In the present work, we aimed to develop a facile, short synthesis for a novel, small presumably reversible inhibitor library designed for SSAO, represented by few relevant examples.

The tert-amino effect as a basis for a ring closure method has been known for more than forty years. ${ }^{28}$ So far seven types of this effect have been recognized, depending on ring size and mode of formation. ${ }^{29,30}$ Stereoselective aspects of the tert-amino effect along with explanations of the mechanism have been discussed in several papers earlier. ${ }^{31-36}$ The Reinhoudt group thoroughly investigated the influence of the steric and electronic effects of substituents on the regioselectivity ${ }^{33}$ and the 'self-reproduction of chirality' - without any auxiliary reagent. ${ }^{31}$ They concluded that the [1,5]-hydrogen shift proceeds enantioselectively in a suprafacial manner. Furthermore, the diastereoselective outcome of the reaction depends on the interchange of the position of the vinyl group, due to the steric hindrance of the vinyl substituents (Scheme 1). According to the X-ray analysis, the authors suggested that the vinyl compound preferentially exists in the conformer A. From this conformer the hydrogen atom $\left(\mathrm{H}_{\mathrm{a}}\right)$ migrates via an 1,5hydrogen shift to the vinyl carbon through a transition state, forming finally the product molecule, where this $\mathrm{H}_{a}$ occupies the position cis relative to the substituent $\mathrm{R}^{2}$. 


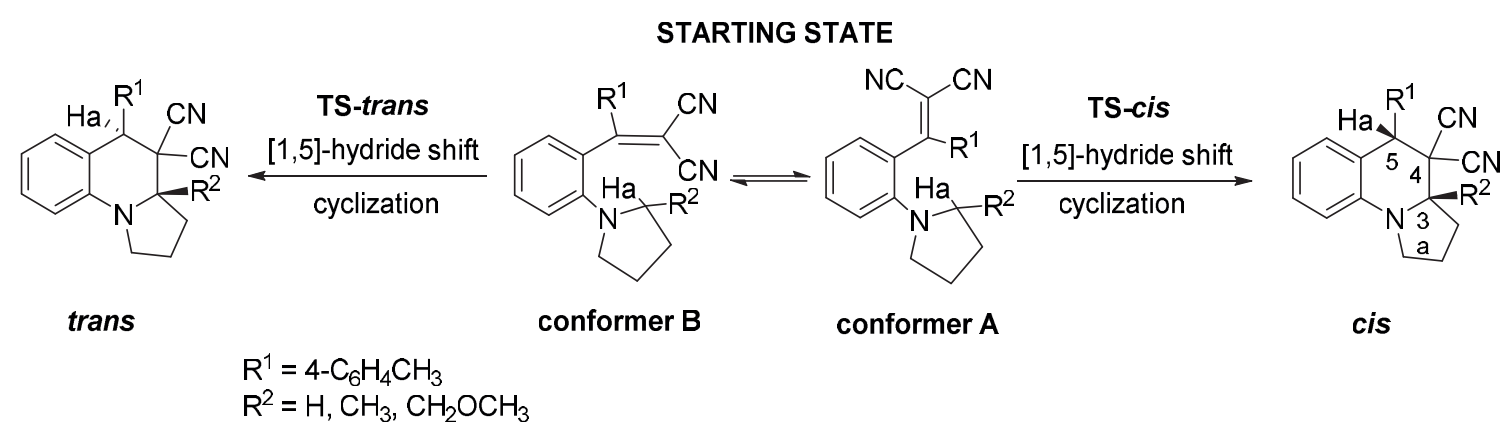

Scheme 1. Reversible interchange between the conformations A and B with differently oriented vinyl groups, leading to two possible cis and trans diastereomers of the cyclized products via two transition states (TS-cis and TS-trans).

Taking into account of the recent applications of cyclizations via tert-amino effect, we can conclude that the synthetic potential of this reaction is unfailing. Siedel and co-workers reported the first catalytic enantioselective tert-amino cyclization reaction using a chiral magnesium complex. ${ }^{37}$ Following this report, several chiral metal complexes were developed for this transformation including cobalt, ${ }^{38}$ gold, ${ }^{39}$ as well as organocatalysts ${ }^{40}$ and phosphoric acid. ${ }^{41}$ Brønsted $^{42}$ and Lewis ${ }^{43}$ acid-catalyzed tert-amino effect were employed for the synthesis of quinalozines and the malonate substituted tetrahydroquinolines in the mild condition. In addition to, a novel type of diastereoselective tert-amino effect was reported by Krasnov and Khrustalev. The reaction was performed in solid state in order to analyse the crystal structure of starting vinyl compound using X-ray diffraction. Selectivity of the reaction was ascribed to the strong intramolecular C-H... $\pi$ interaction in the vinyl compound. ${ }^{44}$ Regio- and diastereoselectivity of the tert-amino effect were investigated via the preparation of biological active 1,4-benzoxazepine derivatives as well. ${ }^{45}$

The microwave-assisted synthesis of tetrahydroquinolines utilizing the tert-amino effect has attracted considerable attention due to its facile, environmentally friendly and efficient outcome. ${ }^{46-}$ 49

\section{Results and Discussion}

A straightforward and rapid, three step procedure was developed and elaborated for the preparation of fused aminomethyl tetrahydroquinoline derivatives (11: $\mathrm{R}^{3}=\mathrm{CH}_{3}$; 12: $\mathrm{R}^{3}=\mathrm{Ph}$ ), possessing different functional groups, in order to demonstrate the synthetic feasibility of the synthesis (Scheme 2). 


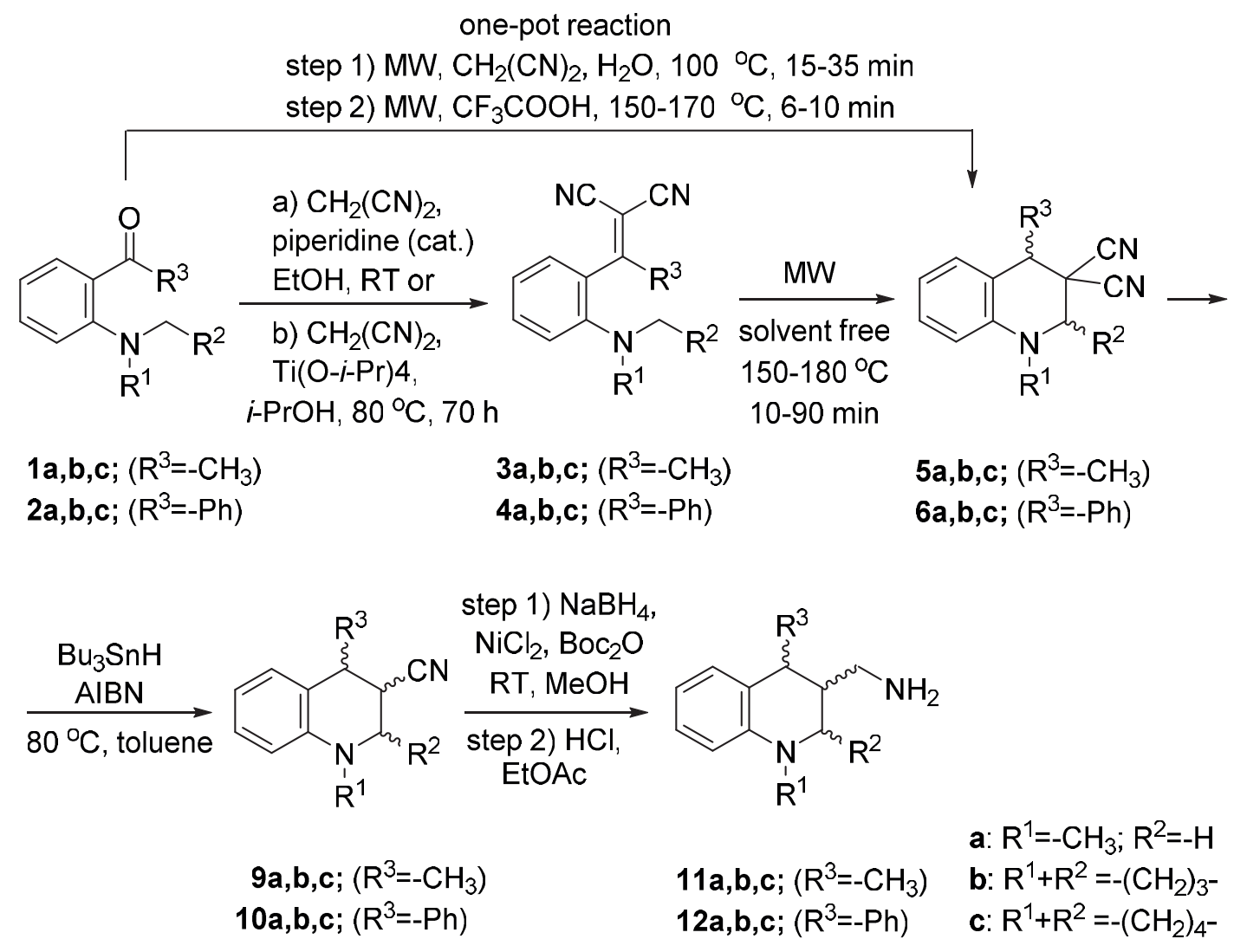

Scheme 2. Synthetic procedure for the preparation of the aminomethyl tetrahydroquinoline derivatives $(\mathbf{1 1}, 12)$.

The synthesis of the tetrahydroquinoline derivatives $(\mathbf{5}, \mathbf{6})$ were executed via a typical Knoevenagel condensation of $\mathbf{1}$ and $\mathbf{2}$ by malononitrile. For compound $\mathbf{1}\left(\mathrm{R}^{3}=\mathrm{CH}_{3}\right)$, the reaction proceeded smoothly at RT in the presence of the catalytic amount of piperidine with excellent yields for $\mathbf{3 a}, \mathbf{b}, \mathbf{c}(88 \%, 75 \%$ and $77 \%$ respectively). The condensation of the benzophenone derivatives $(\mathbf{2} \mathbf{a}, \mathbf{b}, \mathbf{c})$ did not take place under these conditions, presumably because the carbonyl group was hindered by the phenyl substituent. In this case, a much harsher condition found to be optimal [Ti(O-i-Pr $)_{4}$ as Lewis acid and $\left.80{ }^{\circ} \mathrm{C}\right]$ with elongated reaction time, although with moderated to good yields (46-75\%). Noteworthy, that during the elongated and harsh reaction condition $\left(110-120^{\circ} \mathrm{C}, 87 \mathrm{~h}\right)$ compound $\mathbf{2 b}$ transformed to the ring closure products $\mathbf{6} \mathbf{b}$ under the Knoevenagel reaction very effectively ( $35 \%$ yield), and only $6 \%$ of the vinyl product $4 \mathbf{b}$ could be isolated after chromatography. After the isolation of the vinyl products 3, 4, a microwave assisted diastereoselective solvent-free cyclization reaction was performed to afford the required product.

The results of the solvent-free microwave experiments are showed in Table 1. In all cases, the cis isomers were formed predominantly in the ring closure reactions. In case of compounds $\mathbf{5} \mathbf{b}$ and $\mathbf{5 c}$ the solvent-free conditions enabled the formation of the minor trans isomer as well, in contrast 
with the literature data. Reinhoudt and co-workers synthesized the same derivatives $\mathbf{5 b}$,c refluxing $\mathbf{3 b}, \mathbf{c}$ in $n-\mathrm{BuOH}$ for several hours, resulting exlusively in the cis isomer. ${ }^{33}$

The two step procedure was managed to carry out under one-pot conditions in MW reactors in the case of $1\left(\mathrm{R}^{3}=\mathrm{CH}_{3}\right.$, Scheme 2$)$ with relatively good yields $(60 \%)$ and in a stereoselective manner, giving rise solely to the cis isomers (Table 1), previously employed by our group. ${ }^{46}$ The only exception was compound 5a, which was isolated with lower yield, due to the formation of the acid amide side product by the nucleophilic addition of the water to nitrile, which can be a result of the longer reaction time than that applied for compounds $\mathbf{5 b}$, $\mathbf{c}$. In contrast to methyl substituted compounds $(\mathbf{1})$, compound $2\left(\mathrm{R}^{3}=\mathrm{Ph}\right)$ could not be transform to the desired products under analogues conditions (Table 1).

Table 1. Yield and reaction time of the ring closure products obtained by solvent free and onepot reactions starting from compound $\mathbf{1} \mathbf{a}, \mathbf{b}, \mathbf{c}$ and $\mathbf{2 a}, \mathbf{b}, \mathbf{c}$.

\begin{tabular}{|c|c|c|c|c|c|c|c|c|}
\hline \multicolumn{3}{|c|}{ Compounds } & \multicolumn{3}{|c|}{$\begin{array}{c}\text { Solvent free ring } \\
\text { closure step }\end{array}$} & \multicolumn{3}{|c|}{ One-pot reaction } \\
\hline & $\mathrm{R}^{1}+\mathrm{R}^{2}$ & $\mathrm{R}^{3}$ & $\begin{array}{c}\text { Time/temp. } \\
\left(\min /{ }^{\circ} \mathrm{C}\right)\end{array}$ & $\begin{array}{c}\text { Yield } \\
(\%)\end{array}$ & $\begin{array}{c}\text { Isomer } \\
\text { ratio } \\
\mathrm{c} / \mathrm{t}(\%)^{a}\end{array}$ & $\begin{array}{c}\text { React. } \\
\text { time } \\
(\min )^{b}\end{array}$ & $\begin{array}{c}\text { Total } \\
\text { yield }(\%)\end{array}$ & $\begin{array}{l}\text { Isomer } \\
\text { ratio. }^{a}\end{array}$ \\
\hline $5 \mathbf{a}$ & $\mathrm{R}^{1}=\mathrm{CH}_{3}, \mathrm{R}^{2}=\mathrm{H}$ & $\mathrm{CH}_{3}$ & $20 / 180$ & 74 & - & $35+10$ & $10^{d}$ & - \\
\hline $5 b$ & $\left(\mathrm{CH}_{2}\right)_{3}$ & $\mathrm{CH}_{3}$ & $10 / 180$ & $65^{c}$ & $85: 15$ & $15+6$ & 50 & only cis \\
\hline $5 \mathrm{c}$ & $\left(\mathrm{CH}_{2}\right)_{4}$ & $\mathrm{CH}_{3}$ & $10 / 180$ & $70^{c}$ & $92: 8$ & $12+5$ & 60 & only $c i s$ \\
\hline $6 a$ & $\mathrm{R}^{1}=\mathrm{CH}_{3}, \mathrm{R}^{2}=\mathrm{H}$ & $\mathrm{Ph}$ & $90 / 180$ & 67 & - & 60 & no prod. ${ }^{e}$ & - \\
\hline $6 b$ & $\left(\mathrm{CH}_{2}\right)_{3}$ & $\mathrm{Ph}$ & $30 / 150$ & $82^{c}$ & $82: 18$ & 45 & no prod..$^{e}$ & - \\
\hline $6 c$ & $\left(\mathrm{CH}_{2}\right)_{4}$ & $\mathrm{Ph}$ & $10 / 190$ & $95^{c}$ & $71: 29$ & 50 & no prod. ${ }^{e}$ & - \\
\hline
\end{tabular}

${ }^{a}$ Ratio of the diastereomers in the crude product was determined by ${ }^{1} \mathrm{H}$ NMR and/or HPLC. ${ }^{b}$ First: reaction time for the Knoevenagel condensation, second: reaction time for the cyclization ${ }^{c}$ Total yield for the formed cis and trans isomers. ${ }^{d}$ Acid amide side product was also formed in $10 \%$ yield. ${ }^{e}$ According to the TLC a very little amount of the vinyl compound was formed, therefore the reaction was stopped.

The first example of decyanation of dialkylated malononitriles (geminal dinitriles) was published by Curran and Seong, ${ }^{50}$ proposed the geminal substituent effect. In this work, the decyanation reactions of compounds 5a, 5b-cis, $\mathbf{5 c}$-cis and $\mathbf{6 a}, \mathbf{6 b}-\mathbf{c i s}, \mathbf{6 c}$-cis were carried out by radical reduction with tributyltin hydride in the presence of azobisisobutyronitrile (AIBN) in toluene (Scheme 3), based on literature example. ${ }^{51}$ Only two diastereomers were formed during the reaction $(\mathbf{5} \rightarrow \mathbf{9} ; \mathbf{6} \rightarrow \mathbf{1 0})$, as proved by NMR, instead of the theoretically possible four isomers. Column chromatography allowed the separation of the diastereomers, which were employed for the subsequent steps in pure form. The relative configuration of position $3 \mathrm{a}$ and 5 was identified 
as cis (according to the original configuration of $\mathbf{5}$ or $\mathbf{6}$ ) and that of $3 \mathrm{a}$ and 4 was identified as cis or trans (in the name of the compound indicate the second configuration) (Scheme 3).

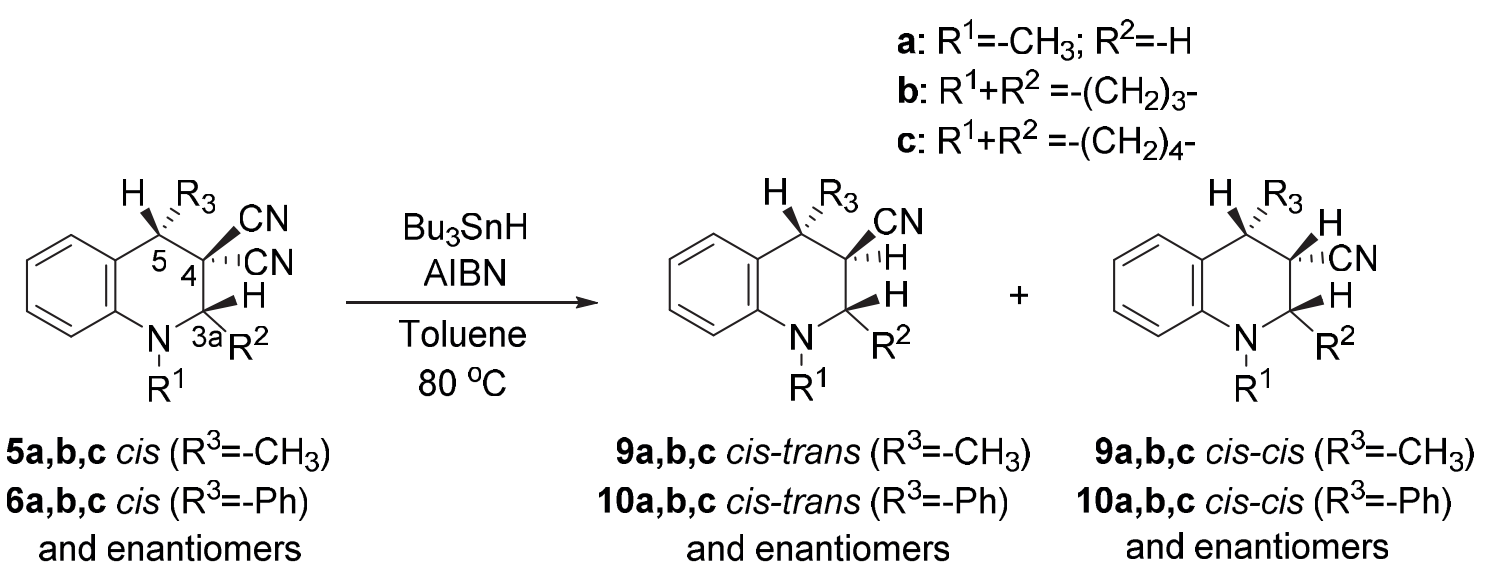

Scheme 3. Chemoselective reductive elimination of the cyano group of the geminal dinitrile. Reductive elimination of the nitrile group from the two different configurations.

The yields, reaction times and the diastereomeric ratios in the crude product are listed in Table 2. In the case of the $\mathrm{R}^{1}=\mathrm{CH}_{3}$ derivatives $(\mathbf{5 a}, \mathbf{6 a})$, the removal of the nitrile group gave rise predominantly (9a) or exclusively (10a) to the cis isomer. Equivalent amounts of cis-cis and cistrans isomers were formed in the case of compounds containing a pyrrolidine ring $(\mathbf{9 b}, \mathbf{1 0 b})$ and predominantly to the $c i s-c i s$ isomer with a piperidine ring $(\mathbf{9 c}, \mathbf{1 0 c})$.

Table 2. Yield and reaction time of the formation of the mononitrile derivatives

\begin{tabular}{lccccc}
\hline Compd. & $\mathrm{R}^{1}+\mathrm{R}^{2}$ & $\mathrm{R}^{3}$ & Reaction time & $\begin{array}{c}\text { Yield } \\
(\%)\end{array}$ & $\begin{array}{c}\text { Isomer ratio } \\
\text { of crude prod. (\%) }\end{array}$ \\
\hline $\mathbf{1 1 b}$ cis-trans & $\mathrm{R}^{1}=\mathrm{CH}_{3}, \mathrm{R}^{2}=\mathrm{H}$ & $\mathrm{CH}_{3}$ & $1.5 \mathrm{~h}$ & $80^{a}$ & c/t $67: 33$ \\
9b & $\left(\mathrm{CH}_{2}\right)_{3}$ & $\mathrm{CH}_{3}$ & $24 \mathrm{~h}$ & $53^{a}$ & c-c/c-t $58: 42$ \\
9c & $\left(\mathrm{CH}_{2}\right)_{4}$ & $\mathrm{CH}_{3}$ & $24 \mathrm{~h}$ & $72^{a}$ & c-c/c-t $72: 28$ \\
10a & $\mathrm{R}^{1}=\mathrm{CH}_{3}, \mathrm{R}^{2}=\mathrm{H}$ & $\mathrm{Ph}$ & $2 \mathrm{~h}$ & 73 & only cis \\
10b & $\left(\mathrm{CH}_{2}\right)_{3}$ & $\mathrm{Ph}$ & $8 \mathrm{~h}$ & $53^{a}$ & c-c/c-t $50: 50$ \\
10c & $\left(\mathrm{CH}_{2}\right)_{4}$ & $\mathrm{Ph}$ & $3 \mathrm{~h}$ & $71^{b}$ & c-c/c-t $95: 5$ \\
\hline
\end{tabular}

${ }^{a}$ Total yield for the formed cis-cis and cis-trans isomers. ${ }^{b}$ Yield for the formed cis-cis isomer.

These results suggest that the size of the $\mathrm{R}^{3}$ substituent (methyl or phenyl) and the type of the secondary amino group (pyrrolidine or piperidine) might influence which nitrile group would be removed from the molecule. The most hindered compound is $\mathbf{6 c}$ with $\mathrm{R}^{3}=\mathrm{Ph}$ and a piperidine ring, therefore the elimination of the nitrile group in the trans position with the phenyl group is preferred (c-c/c-t 95:5). Therefore we can conclude that, except for the 5-ring annelated 
tetrahydroquinoline derivatives $(\mathbf{5 b}, \mathbf{6 b})$, the reductive elimination of a cyano group takes place in a chemo- and stereoselective manners.

The reduction of the mononitrile derivatives (9a-c, 10a-c) was performed as described by Caddik et al. ${ }^{52}$ In the first step, the nitrile group was reduced with sodium borohydride in the presence of a catalytic amount of $\mathrm{NiCl}_{2}$, followed by protection with di-tert-butyl dicarbonate $\left(\mathrm{Boc}_{2} \mathrm{O}\right)$ in methanol (13a-c, 14a-c). In the second step, the carbamate product was isolated and, subsequently, treated with $\mathrm{HCl} / \mathrm{EtOAc}$ at room temperature for 17-48 hours to afford compounds 11a-c and 12a-c (Scheme 4).<smiles>[R]C1c2ccccc2N([R])C([R])C1C#N</smiles>

9a, b, $\mathbf{c}\left(\mathrm{R}^{3}=-\mathrm{CH}_{3}\right)$ $10 a, b, c\left(R^{3}=-P h\right)$

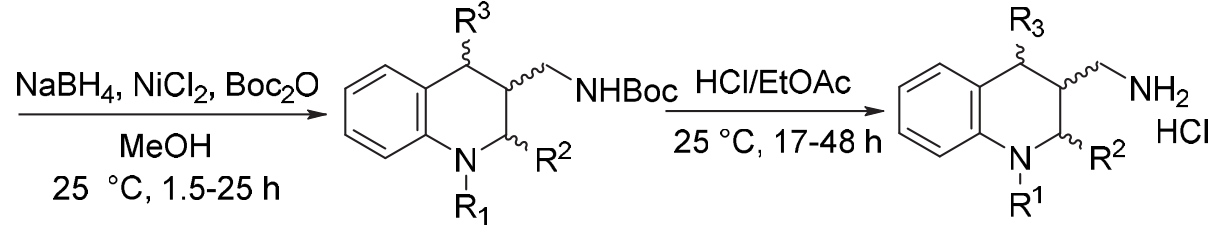

13a, b, $c\left(\mathrm{R}^{3}=-\mathrm{CH}_{3}\right)$ $14 a, b, c\left(R^{3}=-P h\right)$
$11 a, b, c\left(R^{3}=-\mathrm{CH}_{3}\right)$

12a, b, c $\left(R^{3}=-P h\right)$

$\mathrm{R}^{1}=-\mathrm{CH}_{3}, \mathrm{R}^{2}=-\mathrm{H}$

$\mathrm{R}^{1}+\mathrm{R}^{2}=-\left(\mathrm{CH}_{2}\right)_{3}-$

$\mathrm{R}^{1}+\mathrm{R}^{2}=-\left(\mathrm{CH}_{2}\right)_{4}^{-}$

Scheme 4. Preparation of the aminomethyl derivatives $\mathbf{1 1}$ and $\mathbf{1 2}$ via decyanation.

Table 3. Yield and reaction time of the formation of the aminomethyl derivatives

\begin{tabular}{lccc}
\hline Compd. & $\mathrm{R}^{1}+\mathrm{R}^{2}$ & $\mathrm{R}^{3}$ & Yield (\%) \\
\hline 11a cis & $\mathrm{R}^{1}=\mathrm{CH}_{3}, \mathrm{R}^{2}=\mathrm{H}$ & $\mathrm{CH}_{3}$ & 71 \\
11b cis-trans & $\left(\mathrm{CH}_{2}\right)_{3}$ & $\mathrm{CH}_{3}$ & 95 \\
11c cis-trans & $\left(\mathrm{CH}_{2}\right)_{4}$ & $\mathrm{CH}_{3}$ & 29 \\
12a cis & $\mathrm{R}^{1}=\mathrm{CH}_{3}, \mathrm{R}^{2}=\mathrm{H}$ & $\mathrm{Ph}$ & 65 \\
12b cis-trans & $\left(\mathrm{CH}_{2}\right)_{3}$ & $\mathrm{Ph}$ & 54 \\
12c cis-cis & $\left(\mathrm{CH}_{2}\right)_{4}$ & $\mathrm{Ph}$ & 76 \\
\hline
\end{tabular}

Experimental and theoretical considerations of the mechanism of the ring closure. The cyclisation of the vinyl compound $(\mathbf{3}, 4)$ to dicyanotetrahydroquinoline $(5,6)$ still has some unanswered questions about the details. Consequently, it was thougth to be usefull to study the reaction mechanism and diastereoselectivity from experimental and theoretical point of view. The cyclization starts off with the cleavage of the migrating hydrogen $\left(\mathrm{H}_{\mathrm{a}}\right)$ from the $\alpha$ carbon atom of the secondary amino group. This process involves $\mathrm{sp}^{3} \mathrm{C}-\mathrm{H}$ bond activation via $1,5-\mathrm{H}_{\mathrm{a}}$ transfer, affording a dipolar chiral intermediate and a subsequent stereocenter-generating $\mathrm{C}-\mathrm{C}$ bond formation. In general, when $\mathrm{R}^{3}$ is a methyl or phenyl group, the migrating hydrogen $\left(\mathrm{H}_{\mathrm{a}}\right)$ can be traced throughout the course of the reaction and it is in cis position with the anellated hydrogen $\left(\mathrm{H}_{\mathrm{b}}\right)$. Reinhoudt et al linked the exclusive formation of the cis isomer to a specific geometry of the 
vinyl group, the [1,5] suprafacial migration of a hydrogen and the coordinated formation of a carbon-carbon bond. The formation of the trans product may attributed to steric factors, aligning the direction of the vinyl group in the starting compond. ${ }^{33}$

Our experiments verify that the rotamer of the vinyl substance which serves as a starting compound for the formation of the trans isomer via [1,5]-hydrogen migration is also obtained at higher temperatures. To confirm that no interconversion of the diastereomers takes place at the temperature of ring closure, the following experiments were performed. First, the temperature required for the ring closures of $\mathbf{4 b}$, $\mathbf{c}$ was determined using differential scanning calorimetry (DSC). ${ }^{53}$ The obtained thermograms gave a good indication of the melting points (endothermic peaks) of the vinyl substances as well as the ring closure temperatures (exothermic peaks) (see Supplementary Material). Second, the pure cis isomers $\mathbf{5 b}, \mathbf{c}$ and $\mathbf{6 b}, \mathbf{c}$, yielded in the ring closure reactions, were heated at the temperatures required for ring formation. The corresponding ${ }^{1} \mathrm{H} N M R$ assays proved the exclusive presence of the cis isomers. Consequently, one may conclude from that experiment that there was no any transformation from cis to trans isomer, proving that the cis is not an intermediate of the reaction, but one of the final product. In order to determine undoubtedly the relative configuration of the trans isomer, the diastereomers were separated by chromatography, and elucidated by using 1D and 2D NMR spectroscopy.

Examining the substituent effect of the ring closure, one may conclude that there was no significant difference between the effects of the two $\mathrm{R}^{3}$ substituents $\left(\mathrm{CH}_{3}\right.$ or $\left.\mathrm{Ph}\right)$ on the ratio of the diastereomers formed, except in the case of compound $\mathbf{6 c}$, where more of the trans isomer was produced than in the rest of the reactions. My assumption is that the simultaneous presence of the phenyl and piperidino groups on the vinyl compound force the molecule into a defined sterical position, allowing the migrating hydrogen to attack the $\alpha$ carbon atom of the vinyl group from both sides of the molecule, unlike in structures substituted with methyl and piperidino groups which exert a smaller grade of steric hindrance (compound 5c). Based on the published results it seems likely that the hydrogen migration takes place suprafacially and the formation of the trans isomer is controlled by the interchange of the conformation of the vinyl compound in addition to energy relations. The rate of the ring closure reaction is greater in structures containing the more reactive cyclic secondary amino groups (pyrrolidino and piperidino) than in those containing aliphatic (eg. dimethylamino) substituents (Table 1).

Considering Reinhoudt's and our results, we were led to the assumption that the formation of cis and trans diastereomers (5 and 6) depends not only on the steric effect, but also the difference between the activation energies of the cis and the trans transition states (see Scheme 1), in agreement with the Curtin-Hammett principle.

Pharmacological investigation. The SSAO activity of compounds 11a cis, 11b cis-trans, 11c cistrans, 12a cis, 12b cis-trans and 12c cis-cis was tested on the microsomal fraction of rat aorta (Table 5). 4-Phenylbutylamine (4-PBA) was used as the reference substrate, ${ }^{15,54}$ while 2-bromoethylamine (2-BEA) was used as selective, irreversible inhibitor. ${ }^{55}$ According to the hydrogen peroxide formation assay, compounds 11a cis and 12b cis-trans act as inhibitors of 
moderate potency as compared to 2-BEA, while compound $\mathbf{1 1 b}$ cis-trans behave as a substrate $\left(K_{m}=0.94 \pm 0.01 \mu \mathrm{M}\right.$; dose response curves see Supplementary Material). Based on the $\mathrm{K}_{\mathrm{m}}$ data, we can conclude that the affinity of compound 11b cis-trans is higher than that of the substrate 4PBA. The rest of the studied compounds showed only a weak, but promising enzyme inhibitory effect. The structure activity relationship analysis may suggest that pyrrolidine fused ring structure with $\mathrm{Ph}$ substituent (12b cis-trans) exhibits the best combination in the light of the inhibitory activity.

Table 5. Various measured SSAO biological activities [inhibition $\left(\mathrm{IC}_{50}\right)$ and substrate binding constant $\left(\mathrm{K}_{\mathrm{m}}\right)$ ] of the prepared compounds 11a-c and 12a-c as well as the references 2-BEA and 4-PBA

\begin{tabular}{ccc}
\hline Compound & $\mathrm{IC}_{50}(\mu \mathrm{M})$ & $\mathrm{K}_{\mathrm{m}}(\mu \mathrm{M})$ \\
\hline 2-BEA & $0.56 \pm 0.12$ & \\
4-PBA & - & $740 \pm 55$ \\
11a cis & $5.0 \pm 0.4$ & \\
11b cis-trans & - & $0.94 \pm 0.01$ \\
$\mathbf{1 1 c}$ cis-trans & $14.7 \pm 1.0$ & \\
$\mathbf{1 2 a}$ cis & $17.8 \pm 5.2$ & \\
$\mathbf{1 2 b}$ cis-trans & $5.1 \pm 0.5$ & \\
12c cis-cis & $31.0 \pm 6.0$ & \\
\hline
\end{tabular}

a2-BEA = 2-bromoethylamine; b4-PBA = 4-phenylbutylamine;

\section{Conclusions}

A facile microwave-assisted diastereoselective cyclization reaction was developed in order to extend an SSAO inhibitor library, containing condensed aminomethyl tetrahydroquinoline derivatives. The first, diastereoselective cyclizations step based on the known tert-amino effect, providing selectively the cis isomers in all the cases, irrespectively to the two types of $\mathrm{R}^{3}$ substituents $\left(\mathrm{CH}_{3}\right.$ or $\left.\mathrm{Ph}\right)$. The rate of the ring closure reaction is greater in structures containing the more reactive cyclic secondary amino groups (pyrrolidino and piperidino) than in those containing aliphatic (e.g., dimethylamino) substituents. Diastereomers were separated by chromatography then the relative configuration was elaborated by NOE interactions and vicinal coupling constants. The further transformation of the dicyano intermediates included the chemoselective reductive elimination of the cyano group, resulted also two diastereomers, which were separated and fully characterized. The final nitrile reduction step afforded six SSAO active aminomethyl derivatives. One of them showed high enzyme substrate activity, while two other compounds inhibited this enzyme with a moderate potential in a presumably reversibly way, as 
compared to literature references. These compounds proved to be hit molecules for the further biological experiments.

\section{Experimental Section}

General. All reaction solvents were purified in accordance with Purification of Laboratory Chemicals (Fourth Edition) prior to use. All reagents were used as purchased without further purification. The solvents were removed under reduced pressure using standard rotary evaporators. All of the reactions were monitored by TLC using Merck's silica gel 60 F254-precoated aluminum sheets. Visualization was accomplished with UV light (254 or $365 \mathrm{~nm}$ ). Solvent mixtures used for chromatography are always given in a vol/vol ratio. Flash column chromatography was generally performed using Silica Gel 60 (Merck, spherical, 40-63 $\mu \mathrm{m}$ ). Melting points were determined on a Büchi-540 capillary melting point apparatus and are uncorrected. The high-resolution accurate masses (HRMS) were determined with an Agilent 6230 time-of-flight mass spectrometer. Samples were introduced by the Agilent 1260 Infinity LC system. The mass spectrometer was operated in conjunction with a Jet Stream electrospray ion source in positive ion mode. Reference masses of $\mathrm{m} / \mathrm{z} 121.050873$ and 922.009798 were used to calibrate the mass axis during analysis. Mass spectra were processed using Agilent MassHunter B.02.00 software.

High-performance liquid chromatography (HPLC) was performed on a Jasco 2080 Plus isocratic binary pump, using a Jasco 2075 Plus variable wavelength absorbance detector and Jasco ChromPass v.1.8.6.1 software. All samples were dissolved in the mobile phase used for the assay at a level of approximately $1 \mathrm{mg} / \mathrm{mL}$. Stock solutions were diluted 1:20 using the mobile phase, resulting in a concentration of approximately $50 \mu \mathrm{g} / \mathrm{mL}$. The diluted samples were injected without further manipulation. Stock solutions were kept at $-20{ }^{\circ} \mathrm{C}$ overnight. Diluted solutions were prepared on each day of the analysis and were not stored. Chromatographic runs lasted $30 \mathrm{~min}$ typically. When all peaks were recovered, runs were terminated manually regardless of the time that had passed. Two stationary phases were employed with the following parameters: 1) Chiralcel $^{\circledR}{ }^{\circledR}, \mathrm{OJ}-\mathrm{H}$ ” cellulose tris-4-methylbenzoate, $250 \mathrm{~mm}$ x $4.6 \mathrm{~mm}, 5 \mu \mathrm{m} \mathrm{d}$. 2) Chiralpak ${ }^{\circledR}$ „AD-H” amylose tris-(3,5-dimethylphenyl-carbamate), $250 \mathrm{~mm}$ x $4.6 \mathrm{~mm}, 5 \mu \mathrm{m} \mathrm{d}$. The mobile phase was a $n$-hexane/ethanol mixture in all cases. The ratio of the components is provided in the Supplementary Material.

The differential scanning calorimetry (DSC) examinations were carried out with a Pyris 6 DSC (Perkin Elmer) instrument. The DSC curves were evaluated with Pyris Software. The starting and final temperatures were $30{ }^{\circ} \mathrm{C}$ and $300{ }^{\circ} \mathrm{C}$, respectively. Heating rate was 5 and $10{ }^{\circ} \mathrm{C} / \mathrm{min}$. Nitrogen atmosphere was always used. Samples from 0.79 to $3.20 \mathrm{mg}$ were used (in aluminium sample pans). Three parallel examinations were made in every case. The instrument was calibrated by using indium.

Elemental analyses were performed on an Elementar VarioEL III apparatus. MW irradiation 
experiments were carried out in a monomode CEM-Discover MW reactor, using the standard configuration as delivered, including proprietary software. The experiments were executed in 10 or $80 \mathrm{~mL}$ MW process vials with control of the temperature by infrared detection. After completion of the reaction, the vial was cooled to $50{ }^{\circ} \mathrm{C}$ by air jet cooling.

${ }^{1} \mathrm{H}$ and ${ }^{13} \mathrm{C}$ nuclear magnetic resonance (NMR) spectra were recorded at ambient temperature, in the solvent indicated, on a Varian Mercury Plus 400 spectrometer at a frequency of 400 and 100 $\mathrm{MHz}$ or on a Varian Unity 600 spectrometer at a frequency of 600 and $150 \mathrm{MHz}$ or on a Bruker Avance III 500 spectrometer at a frequency of 500 and $125 \mathrm{MHz}$ respectively. Chemical shifts are given using the $\delta$-scale (in ppm) relative to tetramethylsilane or the residual solvent signal as an internal reference. Coupling constants are indicated in Hertz $(\mathrm{Hz})$. The following abbreviations are used for spin multiplicity: s singlet, $d$ doublet, $t$ triplet, q quartet, m multiplet, ovl. m overlapping multiplet, br broad, dd doublet doublet, dm doublet multiplet and tm triplet multiplet. The signification of the one star $(*)$ in the ${ }^{13} \mathrm{C}$ NMR means tentative assignments.

General procedure for the synthesis of 2-(dialkylamino)acetophenone and benzophenone derivetives (method A). A mixture of 2-fluoroacetophenone or 2-fluorobenzophenone (1.0 eq), the appropriate secondary amine (pyrrolidine or piperidine purified by redistillation $(760 \mathrm{mmHg}$, $85-110{ }^{\circ} \mathrm{C}$ ) or dimethylamine (40 wt.\% in water) $\left(1.0 \mathrm{eq}\right.$ ) and $\mathrm{K}_{2} \mathrm{CO}_{3}$ (1.0 eq) in water was irradiated in a pressurized vessel in microwave reactor for the time and the temperature indicated below (at a maximum power level of $200 \mathrm{~W}$ ). The vessel was subsequently cooled to ambient temperature. To the reaction mixture distilled water was added and it was extracted with diethyl ether. The organic layer was washed with saturated solution of $\mathrm{NH}_{4} \mathrm{Cl}$, then with distilled water and then dried over $\mathrm{MgSO}_{4}$, filtered and evaporated under reduced pressure. The crude product was used for the one-pot reaction without further purification. Analytical results of compounds $\mathbf{1}\left(\mathbf{a}, \mathbf{b},{ }^{56} \mathbf{c}^{33}\right)$ and $\mathbf{2}\left(\mathbf{a},{ }^{57} \mathbf{b},{ }^{58} \mathbf{c}^{56}\right)$ are corresponding with the literature data. The atom numbering for NMR assignation follows the scheme below in Scheme 5: 

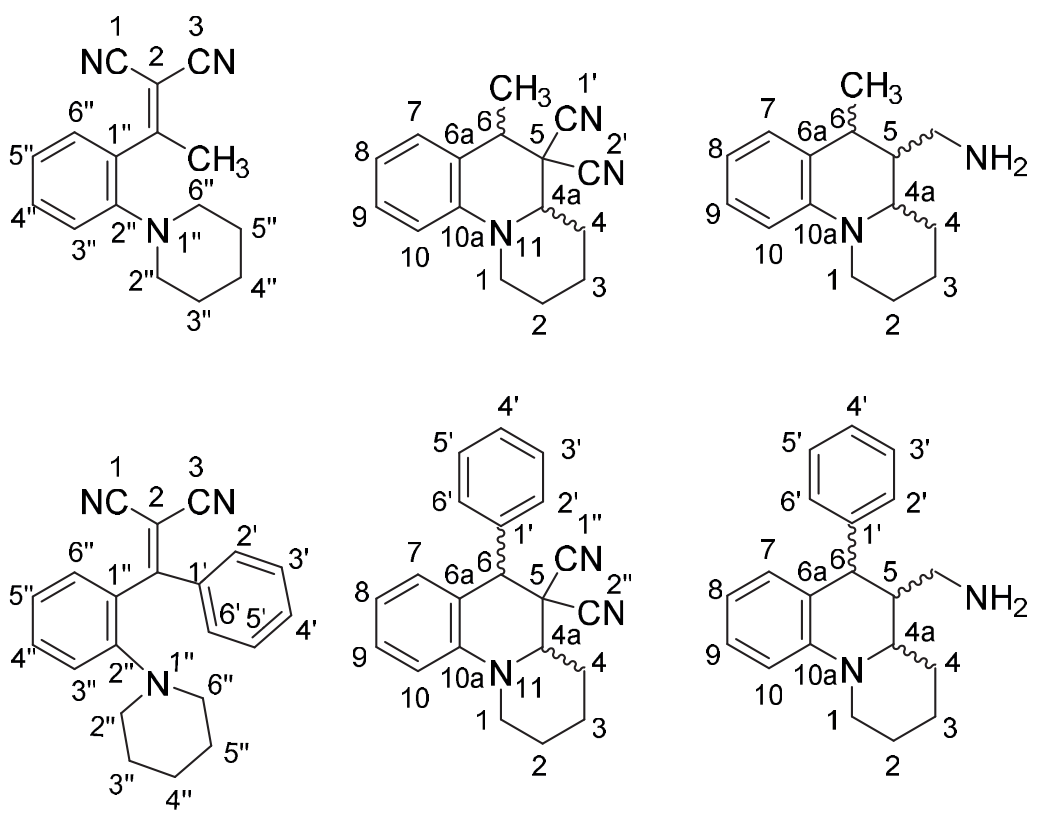

Scheme 5. The scheme of the atom numbering for NMR assignation.

1-[2'-(Dimethylamino)phenyl]ethan-1-one (1a). Following method A, the title compound was isolated. A mixture of 2-fluoroacetophenone $(5.00 \mathrm{~g}, 36.20 \mathrm{mmol}, 4.40 \mathrm{~mL}$ ), dimethylamine (40 wt. \% in water) (1.63 g, $36.20 \mathrm{mmol}, 4.08 \mathrm{~mL})$ and $\mathrm{K}_{2} \mathrm{CO}_{3}(5.00 \mathrm{~g}, 36.20 \mathrm{mmol})$ in $20 \mathrm{~mL}$ water was irradiated at $130{ }^{\circ} \mathrm{C}$ for 35 minutes. Dark oil (5.49 g, 92\%). ${ }^{1} \mathrm{H}$ NMR: (400 MHz, chloroformd): $7.43\left(1 \mathrm{H}, \mathrm{dd}, J 7.6,1.4 \mathrm{~Hz}, \mathrm{H}-6^{\prime}\right), 7.36\left(1 \mathrm{H}, \mathrm{tm}, J 8.3 \mathrm{~Hz}, \mathrm{H}-4^{\prime}\right), 6.99$ (1H, d, J 8.2 Hz, H 3'), 6.93 (1H, tm, J 7.6 Hz, H - 5'), 2.80 (6H, s, H - 1', 2"), 2.61 (3H, s, H - 2).

Before using for the synthesis of the vinyl compound (method B1) the crude product was purified by column chromatography ( $n$-hexane/EtOAc 8:1). Yellow oil $(66 \%)$.

1-[2'-(Pyrrolidin-1"-yl)phenyl]ethan-1-one (1b). Following method A, the title compound was isolated. A mixture of 2-fluoroacetophenone $(5.00 \mathrm{~g}, 36.20 \mathrm{mmol}, 4.40 \mathrm{~mL})$, pyrrolidine $(2.57 \mathrm{~g}$, $36.20 \mathrm{mmol}, 3.02 \mathrm{~mL})$ and $\mathrm{K}_{2} \mathrm{CO}_{3}(5.00 \mathrm{~g}, 36.20 \mathrm{mmol})$ in $20 \mathrm{~mL}$ water was irradiated at $130{ }^{\circ} \mathrm{C}$ for 40 minutes. Brown oil (6.05 g, 88\%). ${ }^{1} \mathrm{H}$ NMR: (400 MHz, chloroform- $d$ ): $7.51(1 \mathrm{H}, \mathrm{dd}, J 7.8$, $\left.1.6 \mathrm{~Hz}, \mathrm{H}-6^{\prime}\right), 7.32$ (1H, tm, $\left.J 8.6 \mathrm{~Hz}, \mathrm{H}-4^{\prime}\right), 6.82\left(1 \mathrm{H}, \mathrm{d}, J 8.5 \mathrm{~Hz}, \mathrm{H}-3^{\prime}\right), 6.74$ (1H, tm, $J$ $7.8 \mathrm{~Hz}, \mathrm{H}-5$ '), 3.15 - 3.11 (4H, m, H - 2", 5”), 2.60 (3H, s, H - 2), 1.97 - 1.93 (4H, m, H - 3", 4 "). Before using for the synthesis of the vinyl compound (method B1) the crude product was purified by column chromatography ( $n$-hexane/EtOAc 8:1). Yellow oil (76\%).

1-[2'-(Piperidin-1"-yl)phenyl]ethan-1-one (1c). Following method $\mathbf{A}$, the title compound was isolated. A mixture of 2-fluoroacetophenone $(5.00 \mathrm{~g}, 36.20 \mathrm{mmol}, 4.40 \mathrm{~mL})$, piperidine $(2.98 \mathrm{~g}$, $36.20 \mathrm{mmol}, 3.46 \mathrm{~mL})$ and $\mathrm{K}_{2} \mathrm{CO}_{3}(5.00 \mathrm{~g}, 36.20 \mathrm{mmol})$ in $30 \mathrm{~mL}$ water was irradiated at $130{ }^{\circ} \mathrm{C}$ for 30 minutes. Yellow oil (6.53 g, 92\%). ${ }^{1} \mathrm{H}$ NMR: (500 MHz, chloroform- $\left.d\right)$ : $7.41-7.39(1 \mathrm{H}$, $\left.\mathrm{dm}, J 7.5 \mathrm{~Hz}, \mathrm{H}-6^{\prime}\right), 7.39-7.36$ (1H, m, H - 4'), 7.06 - 7.05 (1H, dm, J 7.5 Hz, H - 3'), 7.03 - 
7.00 (1H, m, H - 5'), 2.95 - 2.93 (4H, m, H - 2", 6”), 2.67 (3H, s, H - 2), 1.73 - 1.69 (4H, m, H 3", 5"), 1.57 - 1.56 (2H, m, H - 4").

2'-Benzoyl- $N, \boldsymbol{N}$-dimethylaniline (2a). Following $\operatorname{method} \mathbf{A}$, the title compound was isolated. A mixture of 2-fluorobenzophenone $(5.00 \mathrm{~g}, 24.97 \mathrm{mmol}, 4.22 \mathrm{~mL})$, dimethylamine (40 wt. \% in water) (1.13 g, $24.97 \mathrm{mmol}, 2.8 \mathrm{~mL})$ and $\mathrm{K}_{2} \mathrm{CO}_{3}(3.45 \mathrm{~g}, 24.97 \mathrm{mmol})$ in $30 \mathrm{~mL}$ water was irradiated at $130{ }^{\circ} \mathrm{C}$ for 2 hours. Yellow dense oil (5.35 g, 95\%). ${ }^{1} \mathrm{H}$ NMR: (400 MHz, chloroformd): 7.83 (2H, d, J 7.2 Hz, H - 2", 6"), $7.56-7.37$ (4H, m, H - 5', 3", 4”, 5”), 7.33 - 7.31 (1H, dm, $\left.J 7.6 \mathrm{~Hz}, \mathrm{H}-3^{\prime}\right), 7.00$ (1H, d, J 8.3 Hz, H - 6'), 6.90 (1H, m, H - 4'), 2.70 (6H, s, H - 2, 3).

1-(2'-Benzoylphenyl)pyrrolidine (2b). Following method A, the title compound was isolated. A mixture of 2-fluorobenzophenone $(3.00 \mathrm{~g}, 14.98 \mathrm{mmol}, 2.50 \mathrm{~mL})$, pyrrolidine $(1.07 \mathrm{~g}$, $14.98 \mathrm{mmol}, 1.24 \mathrm{~mL})$ and $\mathrm{K}_{2} \mathrm{CO}_{3}(2.07 \mathrm{~g}, 14.98 \mathrm{mmol})$ in $30 \mathrm{~mL}$ water was irradiated at $150{ }^{\circ} \mathrm{C}$ for 2.5 hours. Yellow solid (2.51 g, 67\%). mp 58-60 ${ }^{\circ} \mathrm{C} .{ }^{1} \mathrm{H}$ NMR: $(400 \mathrm{MHz}$, chloroform- $d$ ): 7.95 - 7.93 (2H, m, H - 2", 6”), 7.59 - 7.56 (1H, m, H - 4"), 7.47 - 7.43 (2H, m, H - 3", 5"), 7.39 $7.36\left(1 \mathrm{H}, \mathrm{m}, \mathrm{H}-5^{\prime}\right), 7.27-7.25\left(1 \mathrm{H}, \mathrm{dm}, J 7.7 \mathrm{~Hz}, \mathrm{H}-3^{\prime}\right), 6.85-6.85(1 \mathrm{H}, \mathrm{dm}, J 8.5 \mathrm{~Hz}, \mathrm{H}-$ 6'), $6.69-6.67$ (1H, m, H - 4'), $3.15-3.12$ (4H, m, H - 2, 5), $1.90-1,87$ (4H, m, H - 3, 4).

1-(2'-Benzoylphenyl)piperidine (2c). Following method $\mathbf{A}$, the title compound was isolated. A mixture of 2-fluorobenzophenone (5.00 g, $24.97 \mathrm{mmol}, 4.22 \mathrm{~mL})$, piperidine (2.10 g, $24.97 \mathrm{mmol}$, $2.5 \mathrm{~mL})$ and $\mathrm{K}_{2} \mathrm{CO}_{3}(3.45 \mathrm{~g}, 24.97 \mathrm{mmol})$ in $30 \mathrm{~mL}$ water was irradiated at $150{ }^{\circ} \mathrm{C}$ for 1.5 hours. Yellow solid (6.52 g, 98\%). mp 90.1-91.0 ${ }^{\circ} \mathrm{C} .{ }^{1} \mathrm{H}$ NMR: (400 MHz, chloroform- $d$ ): 7.77 - 7.75 (2H, m, H - 2", 6”), 7.53 - 7.37 (5H, m, H - 3', 5', 3", 4”, 5”) 7.09 - 7.03 (2H, m, H - 4', 6'), $2.83(4 \mathrm{H}, \mathrm{m}, \mathrm{H}-2,6), 1.27(2 \mathrm{H}, \mathrm{m}, \mathrm{H}-4), 1.15$ (4H, m, H - 3, 5).

General procedure for the synthesis of 2-vinyl- $N, N$-dialkylanilines from acetophenone derivatives (method B1). To a mixture of the appropriate acetophenone derivative (1.0 eq) in EtOH, malononitrile (1.0 eq) and 2 drops of piperidine were added. After several hours at room temperature, the yellow solution turned to orange. When the reaction was completed as followed by TLC, the solvent was removed under reduced pressure. The residue was purified by column chromatography to give the pure product. Analytical results of compound $\mathbf{3}\left(\mathbf{a}, \mathbf{b}, \mathbf{c}^{33}\right)$ are corresponding with the literature data.

General procedure for the synthesis of 2-vinyl- $N, N$-dialkylanilines from benzophenone derivatives (method B2). Malononitrile (1.1 eq) and $i-\mathrm{PrOH}$ (distilled from $\mathrm{CaO}$, dried over $4 \AA$ molecular sieves) were placed in a sealed tube under argon atmosphere. To this colorless solution, the appropriate benzophenone $(1 \mathrm{eq})$ and $\mathrm{Ti}(\mathrm{O}-i-\mathrm{Pr})_{4}(1.1 \mathrm{eq})$ were added and the mixture was heated at $70-80{ }^{\circ} \mathrm{C}$. After completion of the reaction, the dark brown reaction mixture was poured into $1 \mathrm{~N} \mathrm{HCl}$ and was vigorously stirred at $0-5{ }^{\circ} \mathrm{C}$ for 0.5 hours. It was extracted by ethyl acetate and the extract was washed with sodium bicarbonate solution and brine. The organic layer was dried over $\mathrm{MgSO}_{4}$ and evaporated. The crude product was purified by column chromatography and washed with diethyl ether to afford the pure product. 
2-\{1'-[2'-(Dimethylamino)phenyl]ethylidene\}propanedinitrile (3a). Following method B1, the title compound was isolated. To a mixture of 1-[2-(dimethylamino)phenyl]ethanone (4.86 g, $29.80 \mathrm{mmol})$ in $50 \mathrm{~mL}$ EtOH, malononitrile $(2.36 \mathrm{~g}, 35.76 \mathrm{mmol}, 1.2 \mathrm{eq})$ and 2 drops piperidine were added. The orange reaction mixture was stirred at room temperature for 15 hours. The crude product was purified by column chromatography ( $n$-hexane/EtOAc 10:1). Orange dense oil (5.52 g, 88\%). ${ }^{1} \mathrm{H}$ NMR (500 MHz, chloroform- $d$ ): 7.43-7.47 (1H, m, H-4'), $7.19(1 \mathrm{H}, \mathrm{dm}, J$ 7.7 Hz, H-3'), 7.09 (1H, dm, J 8.3 Hz, H-6'), 7.05-6.99 (1H, m, H-5'), 2.75 (6H, s, H-1”, 2”), 2.63 $\left(3 \mathrm{H}, \mathrm{s}, \mathrm{CH}_{3}\right) ;{ }^{13} \mathrm{C}$ NMR (125 MHz, chloroform- $d$ ): $179.2\left(=\mathrm{C}_{\mathrm{q}} \mathrm{CH}_{3}\right), 151.3\left(\mathrm{C}-2^{\prime}\right), 132.2\left(\mathrm{C}-4^{\prime}\right)$, 129.1 (C-1'), 128.9 (C-6'), 121.5 (C-5'), 118.8 (C-3'), 112.7* (C-1), 112.6* (C-3), 85.5 (C-2), 43.7 (C-1", 2"), $22.8\left(\mathrm{CH}_{3}\right)$. HRMS (ESI+) $\mathrm{m} / z$ calcd. for $\mathrm{C}_{13} \mathrm{H}_{14} \mathrm{~N}_{3}[\mathrm{M}+\mathrm{H}]^{+} 212.1182$, found 212.1190 .

2-\{1'-[2'-(Pyrrolidin-1"'-yl)phenyl]ethylidene\}propanedinitrile (3b). Following method B1, the title compound was isolated. To a mixture of 2-(pyrrolidin-1-yl)acetophenone (1.00 g, 5.28 $\mathrm{mmol})$ in $10 \mathrm{~mL} \mathrm{EtOH}$, malononitrile $(0.35 \mathrm{~g}, 5.28 \mathrm{mmol})$ and 2 drops piperidine were added. The orange reaction mixture was stirred at room temperature for 24 hours. The crude product was purified by column chromatography (toluene) and washed with diethyl ether to afford the pure product. Orange crystals $(0.94 \mathrm{~g}, 75 \%)$. mp 106.0-107.9 ${ }^{\circ} \mathrm{C} .{ }^{1} \mathrm{H} \mathrm{NMR}$ : (400 MHz, chloroform- $d$ ): 7.36 - 7.29 (1H, m, H-4'), 7.14 (1H, dm, J 7.9 Hz, H-3'), 6.90 (1H, dm, J 8.5 Hz, H-6'), 6.87 6.80 (1H, m, H-5'), 3.22-3.05 (4H, m, H-2", 5”), 2.59 (3H, s, CH3), 2.03 - 1.94 (4H, m, H-3", 4”); ${ }^{13} \mathrm{C}$ NMR: (100 MHz, chloroform- $d$ ): $178.6\left(=C_{\mathrm{q}} \mathrm{CH}_{3}\right), 147.4(\mathrm{C}-2$ ') 132.0 (C-4'), 129.0 (C-1'), 123.4 (C-6'), 117.8 (C-5'), 115.0 (C-3'), 113.1* (C-1), 112.4* (C-3), 84.1 (C-2), 51.1 (C-2”, 5”), 25.8 (C-3", 4"), $23.7\left(\mathrm{CH}_{3}\right)$. Anal. calcd. for $\mathrm{C}_{15} \mathrm{H}_{15} \mathrm{~N}_{3}$ (237.29): C, 75.92\%; H, 6.37\%; N, 17.71\%. Found: C, 75.59\%; H, 6.18\%; N, 17.30\%. HRMS (ESI+) $\mathrm{m} / z$ calcd. for $\mathrm{C}_{15} \mathrm{H}_{16} \mathrm{~N}_{3}[\mathrm{M}+\mathrm{H}]^{+}$ 238.1339 , found 238.1343 .

2-\{1'-[2'-(Piperidin-1"'-yl)phenyl]ethylidene\}propanedinitrile (3c). Following method B1, the title compound was isolated. To a mixture of 2-(piperidin-1-yl)acetophenone $(0.80 \mathrm{~g}, 3.94 \mathrm{mmol})$ in $10 \mathrm{~mL}$ EtOH, malononitrile $(0.26 \mathrm{~g}, 3.94 \mathrm{mmol})$ and 2 drops piperidine were added. The yellow reaction mixture was stirred at room temperature for 21 hours. The crude product was purified by column chromatography ( $n$-hexane/EtOAc 4:1). Yellow crystals $(0.76 \mathrm{~g}, 77 \%)$ mp 100.6-101.9 ${ }^{\circ} \mathrm{C} .{ }^{1} \mathrm{H}$ NMR: (400 MHz, chloroform- $d$ ): 7.45 - 7.41 (1H, m, H-4'), 7.20 - 7.18 (1H, m, H-6'), 7.16 - 7.14 (1H, m, H-3'), 7.10 - 7.08 (1H, m, H-5'), 2.87 (4H, t, J 8.0 Hz, H-2”, 6”), 2.68 (3H, s, $\mathrm{CH}_{3}$ ), 1.73 - 1.69 (4H, m, H-3", 5"), 1.59 - 1.57 (2H, m, H-4"); ${ }^{13} \mathrm{C}$ NMR: (100 MHz, chloroformd): $178.9\left(=C_{q} \mathrm{CH}_{3}\right), 151.9$ (C-2'), 132.2 (C-4'), 131.2 (C-1'), 128.6 (C-6'), 122.8 (C-5'), 120.2 (C-3'), 112.7* (C-1), 112.6* (C-3), 86.1 (C-2), 53.8 (C-2”, 6”), 26.2 (C-3", 5”), 23.9 (C-4”), 23.4 $\left(\mathrm{CH}_{3}\right)$. Anal. calcd. for $\mathrm{C}_{16} \mathrm{H}_{17} \mathrm{~N}_{3}$ (251.33): C, 76.46\%; $\mathrm{H}, 6.82 \%$; N, 16.72\%. Found: $\mathrm{C}, 76.05 \%$; $\mathrm{H}, 6.62 \%$; N, 16.37\%. HRMS (ESI+) $m / z$ calcd. for $\mathrm{C}_{15} \mathrm{H}_{18} \mathrm{~N}_{3}[\mathrm{M}+\mathrm{H}]^{+} 252.1495$, found 252.1504 . 2-\{[2"-(Dimethylamino)phenyl](phenyl)methylidene\}propanedinitrile (4a). Following method B2, the title compound was isolated. To a mixture of malononitrile $(0.55 \mathrm{~g}, 8.40 \mathrm{mmol})$ in $i$-PrOH $(20 \mathrm{~mL})$, [2-(dimethylamino)phenyl](phenyl)methanone $(1.90 \mathrm{~g}, 8.40 \mathrm{mmol})$ and Ti(O$i$-Pr $)_{4}(2.39 \mathrm{~g}, 8.40 \mathrm{mmol}, 2.50 \mathrm{~mL})$ were added. The dark red reaction mixture was stirred at $70{ }^{\circ} \mathrm{C}$ 
for 71 hours. The crude product was purified by column chromatography (toluene). Red crystals (1.66 g, 75\%). mp 116-119 ${ }^{\circ} \mathrm{C} .{ }^{1} \mathrm{H}$ NMR: (400 MHz, chloroform-d): 7.52 -7.49 (1H, m, H-4'), 7.48 - 7.46 (2H, m, H-2', 6'), $7.44-7.42$ (3H, m, H-3', 5', 4’), 7.17 (1H, dd, J 7.7 and $1.4 \mathrm{~Hz}, \mathrm{H}-$ 6”), 7.05 (1H, d, J 8.2 Hz, H-3"), 6.99 (1H, t, J 7.7 Hz, H-5"), 2.66 (6H, s, H-1"', 2"'); ${ }^{13} \mathrm{C}$ NMR: (100 MHz, chloroform- $d$ ): 175.2 (=C $\left.C_{\mathrm{q}} \mathrm{Ph}\right) 152.8$ (C-2”), 135.9 (C-1'), 132.9 (C-4”), 132.4 (C-4'), 132.3 (C-6”), 129.6 (C-3', 5'), 128.6 (C-2', 6'), 127.6 (C-1”), 120.6 (C-5”), 118.6 (C-3”), 114.4* (C-3), 114.1* (C-1), 81.4 (C-2), 43.1 (C-1"', 2"'). Anal. calcd. for $\mathrm{C}_{18} \mathrm{H}_{15} \mathrm{~N}_{3}$ (273.33): C, 79.10\%; H, 5.53\%; N, 15.37\%. Found: C, 78.95\%; H, 5.49\%; N, 15.21\%. HRMS (ESI+) $m / z$ calcd. for $\mathrm{C}_{18} \mathrm{H}_{16} \mathrm{~N}_{3}[\mathrm{M}+\mathrm{H}]^{+} 274.1339$, found 274.1345 .

2-\{Phenyl[2"-(pyrrolidin-1"'-yl)phenyl]methylidene\}propanedinitrile (4b). Following method B2, the title compound was isolated, however the major product was the cyclized derivative (see below compound $\mathbf{6 b}$ ). To a mixture of malononitrile $(1.31 \mathrm{~g}, 19.89 \mathrm{mmol})$ in $i$ PrOH (70 mL), phenyl[2-(pyrrolidin-1-yl)phenyl]methanon (5.00 g, $19.89 \mathrm{mmol})$ and Ti(O- $i$-Pr $)_{4}$ $(5.65 \mathrm{~g}, 19.89 \mathrm{mmol}, 5.88 \mathrm{~mL})$ were added. The dark red reaction mixture was stirred at $80{ }^{\circ} \mathrm{C}$ for 96 hours. Dark red crystals $\left(0.36\right.$ g, 6\%). mp 148.2-151.1 ${ }^{\circ} \mathrm{C} .{ }^{1} \mathrm{H}$ NMR: (400 MHz, chloroformd): $7.64-7.52$ (3H, m, H-2', 4', 6'), $7.51-7.41$ (2H, m, H-3', 5'), 7.40 - 7.33 (1H, m, H-4”), 6.93 (1H, dm, J $8.5 \mathrm{~Hz}, \mathrm{H}-3$ ”), 6.87 (1H, dm, J 8.1 Hz, H-6”), 6.73 (1H, m, H-5”), 3.48 - 2.92 (4H, brm, H-2"', 5"'), 2.13 - 1.81 (4H, brm, H-3"', 4"'); ${ }^{13} \mathrm{C}$ NMR: (100 MHz, chloroform- $d$ ): 174.7 (=C $\left.C_{\mathrm{q}} \mathrm{Ph}\right), 148.8$ (C-2”), 136.6 (C-1'), 133.0 (C-4”), 132.8 (C-4'), 132.5 (C-6”), 130.7 (C-1"), 129.0 (C-2', 6'), 128.7 (C-3', 5'), 121.4 (C-5”), 116.9 (C-3”), 114.9* (C-1), 113.7* (C-3), 78.7 (C-2), 51.0 (C-2"', 5"'), 25.9 (C-3"', 4"'). HRMS (ESI+) $\mathrm{m} / \mathrm{z}$ calcd. for $\mathrm{C}_{20} \mathrm{H}_{18} \mathrm{~N}_{3}[\mathrm{M}+\mathrm{H}]^{+} 300.1495$, found 300.1497.

2-\{Phenyl[2"-(piperidin-1"'-yl)phenyl]methylidene\}propanedinitrile (4c). Following method B2, the title compound was isolated. To a mixture of malononitrile $(2.50 \mathrm{~g}, 37.68 \mathrm{mmol})$ in $i$-PrOH $(70 \mathrm{~mL}), \quad 1-\left(2\right.$ '-benzoylphenyl)piperidine $(10.0 \mathrm{~g}, 37.68 \mathrm{mmol})$ and $\mathrm{Ti}(\mathrm{O}-\mathrm{i}-\mathrm{Pr})_{4} \quad(10.72 \mathrm{~g}$, $37.68 \mathrm{mmol}, 11.2 \mathrm{~mL}$ ) were added. The dark orange reaction mixture was stirred at $80{ }^{\circ} \mathrm{C}$ for 7 hours. The crude product was purified by column chromatography ( $n$-hexane/EtOAc 9:1). Orange crystals (46\%). mp 166-168 ${ }^{\circ} \mathrm{C}$. ${ }^{1} \mathrm{H}$ NMR: (500 MHz, chloroform- $\left.d\right)$ : $7.57-7.36(5 \mathrm{H}, \mathrm{m}$, H-2', 3', 4', 5', 6'), 7.48 (1H, m, H-4'), 7.25 (1H, dm, J 6.5 Hz, H-6”), 7.13 (1H, dm, J $1.0 \mathrm{~Hz}$, H-3"), 7.11 (1H, m, H-5"), 2.77 (4H, brs, H-2"', 6"'), 1.50 - 1.25 (6H, brm, H-3"', 4"', 5"'); ${ }^{13} \mathrm{C}$ NMR: (125 MHz, chloroform- $d$ ): 174.9 (=C $\left.C_{\mathrm{q}} \mathrm{Ph}\right), 153.7$ (C-2”), 136.0 (C-1'), 133.0 (C-4”), 132.4 (C-4'), 131.9 (C-6”), 131.1 (C-1”), 129.7 (C-2', 6'), 128.5 (C-3', 5'), 122.6 (C-5”), 120.8 (C-3"), 114.3* (C-1), 114.2* (C-3), 82.1 (C-2), 53.4 (C-2"', 6"'), 25.9 (C-3"', 5"'), 23.8 (C-4"'). Anal. calcd. for $\mathrm{C}_{21} \mathrm{H}_{19} \mathrm{~N}_{3}$ (313.40): C, 80.48\%; H, 6.11\%; N, 13.41\%. Found: C, $80.74 \%$; H, $6.18 \%$; N, 13.33\%. HRMS (ESI+) $m / z$ calcd. for $\mathrm{C}_{21} \mathrm{H}_{19} \mathrm{~N}_{3}[\mathrm{M}+\mathrm{H}]^{+} 314.1652$, found 314.1640 .

General procedure for the synthesis of pyrido-fused ring system - one-pot reaction (method C1). Step 1. To a mixture of the appropriate acetophenone $(1.0$ eq) in $30 \mathrm{~mL}$ of water, malononitrile (1.0 eq) was added. The reaction mixture was irradiated in a pressurized vessel for the time and the temperature indicated below (at a maximum power level of $200 \mathrm{~W}$ ). The vessel 
was subsequently cooled to ambient temperature, monitoring the completion of the reaction by TLC. The reaction mixture was used for the next step without work-up and purification.

Step 2.: To the reaction mixture trifluoroacetic acid was added in catalytic amount (3 drops). The vinyl precursor was irradiated in a pressurized vessel for the time and the temperature indicated below (at a maximum power level of $200 \mathrm{~W}$ ). The vessel was subsequently cooled to ambient temperature, the crude product was taken for the analysis of the ratio of the diastereomers by NMR. After transferring from the vial, the reaction mixture was extracted with dichloromethane $(3 \times 30 \mathrm{~mL})$. The organic layer was dried over $\mathrm{MgSO}_{4}$ and evaporated under reduced pressure. The crude product was purified by crystallization or filtration.

General procedure for the synthesis of pyrido-fused ring system - solvent free reaction (method C2). The vinyl precursor was irradiated in a sealed vessel without solvent. When the reaction was completed as followed by TLC, the vessel was subsequently cooled to ambient temperature. The crude product was taken for the analysis of the ratio of the diastereomers by NMR. After transferring from the vial, to the reaction mixture dichloromethane $(20 \mathrm{~mL})$ and water $(20 \mathrm{~mL})$ were added, then the water phase was extracted with dichloromethane $(2 \times 30 \mathrm{~mL})$. The organic layer was washed with saturated solution of $\mathrm{NH}_{4} \mathrm{Cl}(60 \mathrm{~mL})$, then dried over $\mathrm{MgSO}_{4}$ and evaporated under reduced pressure. The crude product was purified by column chromatography and/or crystallization.

( \pm )-1,4-Dimethyl-1,2,3,4-tetrahydroquinoline-3,3-dicarbonitrile (5a). Following method C1, the title compound was isolated. (1. step) To a mixture of 2-(dimethylamino)acetophenone (5.50 g, $33.70 \mathrm{mmol})$ in $30 \mathrm{~mL}$ of water, malononitrile $(2.22 \mathrm{~g}, 33.70 \mathrm{mmol})$ was added. The reaction mixture was irradiated at $100{ }^{\circ} \mathrm{C}$ for $35 \mathrm{~min}$, then (2. step) to the reaction mixture trifluoroacetic acid was added and it was irradiated at $165^{\circ} \mathrm{C}$ for $10 \mathrm{~min}$. The crude product was purified by column chromatography (toluene), then was washed with $n$-hexane (in the reaction $10 \%$ side product was formed, see below). Pale yellow crystals (0.44 g, 6\%). mp 86.0-86.8 ${ }^{\circ} \mathrm{C} .{ }^{1} \mathrm{H}$ NMR (500 MHz, chloroform-d): $7.22-7.21(1 \mathrm{H}, \mathrm{m}, \mathrm{H}-7), 7.12(1 \mathrm{H}, \mathrm{dm}, J 8.0 \mathrm{~Hz}, \mathrm{H}-6), 6.83-6.80$ $(1 \mathrm{H}, \mathrm{m}, \mathrm{H}-5), 6.71(1 \mathrm{H}, \mathrm{dm}, J 8.5 \mathrm{~Hz}, \mathrm{H}-8), 3.78\left(1 \mathrm{H}, \mathrm{dm}, J 12.0 \mathrm{~Hz}, \mathrm{H}_{\mathrm{x}}-2\right), 3.74(1 \mathrm{H}, \mathrm{dm}, J 12.0$ $\left.\mathrm{Hz}, \mathrm{H}_{\mathrm{y}}-2\right), 3.49(1 \mathrm{H}, \mathrm{q}, J 7.0 \mathrm{~Hz}, \mathrm{H}-4), 3.06(3 \mathrm{H}, \mathrm{s}, \mathrm{NCH}), 1.64\left(3 \mathrm{H}, \mathrm{d}, J 7.0 \mathrm{~Hz}, \mathrm{CH}_{3}\right) ;{ }^{13} \mathrm{C} \mathrm{NMR}$ (125 MHz, chloroform- $d$ ): 142.9 (C-8a), 129.0 (C-7), 128.1 (C-5), 120.2 (C-4a), 118.6 (C-6), 114.8* (C-2'), 113.3* (C-1'), 112.3 (C-8), 54.1 (C-2), 39.6 (C-4), $39.4\left(\mathrm{NCH}_{3}\right), 36.7$ (C-3), 19.0 $\left(\mathrm{CH}_{3}\right)$. Anal. calcd. for $\mathrm{C}_{13} \mathrm{H}_{13} \mathrm{~N}_{3}(211.26)$ : C, 73.91\%; H, 6.20\%; N, 19.89\%. Found: $\mathrm{C}, 73.53 \%$; $\mathrm{H}, 6.15 \%$; N, 19.86\%. HRMS (ESI+) $m / z$ calcd. for $\mathrm{C}_{13} \mathrm{H}_{14} \mathrm{~N}_{3}[\mathrm{M}+\mathrm{H}]^{+} 212.1182$, found 212.1188 . Following method C2, the title compound was isolated. The vinyl precursor $(0.98 \mathrm{~g}, 4.62 \mathrm{mmol})$ was irradiated at $180{ }^{\circ} \mathrm{C}$ for 20 minutes. The crude product was washed with $n$-hexane. Pale yellow crystals $(0.73 \mathrm{~g}, 74 \%)$.

3-Cyano-1,4-dimethyl-1,2,3,4-tetrahydroquinoline-3-carboxamide (side product). Following method C1, the title compound was isolated. Cream powder $(0.69 \mathrm{~g}, 10 \%)$, mp 160.3-161.1 ${ }^{\circ} \mathrm{C}$. According to the NMR analysis the diastereomer ratio is $80: 20$ cis/trans. ${ }^{1} \mathrm{H}$ NMR $(500 \mathrm{MHz}$, 
chloroform- $d$ ): 7.20 - 7.17 (1H, m, H-7), $7.08(1 \mathrm{H}, \mathrm{dm}, J 8.5 \mathrm{~Hz}, \mathrm{H}-5), 6.75(1 \mathrm{H}, \mathrm{dm}, J 7.5 \mathrm{~Hz}, \mathrm{H}-$ 6), $6.72(1 \mathrm{H}, \mathrm{dm}, J 8.0 \mathrm{~Hz}, \mathrm{H}-8), 6.35\left(1 \mathrm{H}\right.$, brs, $\left.\mathrm{N} H_{2}\right), 5.75\left(1 \mathrm{H}\right.$, brs, $\left.\mathrm{NH}_{2}\right) 3.73(1 \mathrm{H}, \mathrm{d}, J 17.5 \mathrm{~Hz}$, $\left.\mathrm{H}_{\mathrm{x}}-2\right), 3.46\left(1 \mathrm{H}, \mathrm{d}, J 14.0 \mathrm{~Hz}, \mathrm{H}_{\mathrm{y}}-2\right), 3.41(1 \mathrm{H}, \mathrm{q}, J 7.0 \mathrm{~Hz}, \mathrm{H}-4), 3.03(3 \mathrm{H}, \mathrm{s}, \mathrm{H}-\mathrm{NCH}), 1.32(3 \mathrm{H}$, $\left.\mathrm{d}, J 7.5 \mathrm{~Hz}, \mathrm{CH}_{3}\right) ;{ }^{13} \mathrm{C}$ NMR (125 MHz, chloroform- $d$ ): $167.3(\mathrm{C}=\mathrm{O}), 143.5(\mathrm{C}-8 \mathrm{a}), 128.9$ (C-5), 128.5 (C-7), 122.8 (C-4a), 120.2 (CN), 117.8 (C-6), 111.9 (C-8), 50.1 (C-2), 45.8 (C-3), 40.1 (C4), $39.1\left(\mathrm{NCH}_{3}\right), 20.0\left(\mathrm{CH}_{3}\right)$. HRMS (ESI+) $\mathrm{m} / z$ calcd. for $\mathrm{C}_{14} \mathrm{H}_{16} \mathrm{~N}_{2} \mathrm{O}[\mathrm{M}+\mathrm{H}]^{+} 229.1335$, found: 229.1342 .

\section{cis-( \pm )-5-Methyl-1,2,3,3a,4,5-hexahydropyrrolo[1,2-a]quinoline-4,4-dicarbonitrile}

(5b cis $)^{33}$ and trans-( \pm )-5-Methyl-1,2,3,3a,4,5-hexahydropyrrolo[1,2-a]quinoline-4,4dicarbonitrile (5b trans). Following method $\mathbf{C 1}$, the title compound (5b cis) was isolated. (1. step) To a mixture of 2-(pyrrolidino)acetophenone $(6.58 \mathrm{~g}, 34.80 \mathrm{mmol})$ in $40 \mathrm{~mL}$ water, malononitrile $(2.30 \mathrm{~g}, 34.80 \mathrm{mmol})$ was added. The reaction mixture was irradiated at $100{ }^{\circ} \mathrm{C}$ for 15 minutes, then (2. step) to the reaction mixture trifluoroacetic acide was added and it was irradiated at $150{ }^{\circ} \mathrm{C}$ for $6 \mathrm{~min}$. The ratio of the diastereomers in the crude product by NMR: only cis isomer was formed. The crude solid product was washed with $\mathrm{Et}_{2} \mathrm{O}$ and crystallized from $\mathrm{EtOH}$ (anhydrous, dried over $3 \AA$ molecular sieves). White crystals $(4.12 \mathrm{~g}, 50 \%)$. mp $134.0-134.5^{\circ} \mathrm{C}$. ${ }^{1} \mathrm{H}$ NMR (500 MHz, chloroform- $d$ ): 7.25 - 7.16 (2H, m, H-6, 8), $6.82-6.75$ (1H, m, H-7), 6.57 $(1 \mathrm{H}, \mathrm{dm}, J 8.0 \mathrm{~Hz}, \mathrm{H}-9), 3.92(1 \mathrm{H}, \mathrm{dd}, J 9.0$ and $6.0 \mathrm{~Hz}, \mathrm{H}-3 \mathrm{a}), 3.56-3.40(2 \mathrm{H}, \mathrm{m}, \mathrm{H}-1) 3.48(1 \mathrm{H}$, q, J 7.0 Hz, H-5), $2.60-2.50\left(1 \mathrm{H}, \mathrm{m}, \mathrm{H}_{\mathrm{x}}-3\right), 2.27-2.06\left(3 \mathrm{H}, \mathrm{m}, \mathrm{H}_{\mathrm{x}, \mathrm{y}}-2, \mathrm{H}_{\mathrm{y}}-3\right), 1.77(3 \mathrm{H}, \mathrm{d}, J$ $\left.7.0 \mathrm{~Hz}, \mathrm{H}-\mathrm{CH}_{3}\right) ;{ }^{13} \mathrm{C}$ NMR (125 MHz, chloroform- $d$ ): 141.9 (C-9a), 129.1 (C-8), 126.8 (C-6), 118.7 (C-5a), 117.6 (C-7), 115.3* (C-1'), 112.0* (C-2'), 111.9 (C-9), 63.0 (C-3a), 48.1 (C-1), 42.3 (C-4), 41.1 (C-5), 30.3 (C-3), $22.7(\mathrm{C}-2), 16.1\left(\mathrm{C}-\mathrm{CH}_{3}\right)$. Anal. calcd. for $\mathrm{C}_{15} \mathrm{H}_{15} \mathrm{~N}_{3}$ (237.30): $\mathrm{C}$, 75.92\%; H, 6.37\%; N, 17.71\%. Found: C, 75.90\%; H, 6.41\%; N, 17.87\%. HRMS (ESI+) $\mathrm{m} / z$ calcd. for $\mathrm{C}_{15} \mathrm{H}_{16} \mathrm{~N}_{3}[\mathrm{M}+\mathrm{H}]^{+} 238.1339$, found 238.1334 .

Following method $\mathbf{C 2}$, the title compound (5b trans) was isolated. The vinyl precursor $(0.20 \mathrm{~g}$, $0.84 \mathrm{mmol}$ ) was irradiated at $180^{\circ} \mathrm{C}$ for 10 minutes. The ratio of the diastereomers in the crude product by NMR: cis/trans $85: 15$. The crude product was purified by column chromatography (toluene). Pale yellow crystals $(0.13 \mathrm{~g}, 65 \%)$. The two diastereomers were separated by HPLC. 5b trans isomer. $\mathrm{mp} 125.1-125.8^{\circ} \mathrm{C} .{ }^{1} \mathrm{H}$ NMR $(500 \mathrm{MHz}$, chloroform- $d)$ : $7.21-7.18(1 \mathrm{H}, \mathrm{m}, \mathrm{H}-8)$, 7.09 (1H, dm, J 8.0 Hz, H-6), $6.76-6.73(1 \mathrm{H}, \mathrm{m}, \mathrm{H}-7), 6.60(1 \mathrm{H}, \mathrm{dm}, J 8.0 \mathrm{~Hz}, \mathrm{H}-9), 3.85(1 \mathrm{H}$, dd, J 9.0 and $6.0 \mathrm{~Hz}, \mathrm{H}-3 \mathrm{a}), 3.60\left(1 \mathrm{H}, \mathrm{m}, \mathrm{H}_{\mathrm{x}}-1\right), 3.59(1 \mathrm{H}, \mathrm{m}, \mathrm{H}-5), 3.42\left(1 \mathrm{H}, \mathrm{m}, \mathrm{H}_{\mathrm{y}}-1\right), 2.52(1 \mathrm{H}$, m, $\left.\mathrm{H}_{\mathrm{x}}-3\right), 2.28\left(1 \mathrm{H}, \mathrm{m}, \mathrm{H}_{\mathrm{x}}-2\right), 2.18\left(1 \mathrm{H}, \mathrm{m}, \mathrm{H}_{\mathrm{y}}-3\right), 2.10\left(1 \mathrm{H}, \mathrm{m}, \mathrm{H}_{\mathrm{y}}-2\right), 1.50\left(3 \mathrm{H}, \mathrm{d}, J 7.0 \mathrm{~Hz}, \mathrm{CH}_{3}\right)$; ${ }^{13} \mathrm{C}$ NMR (125 MHz, chloroform- $d$ ):140.9 (C-9a), 129.1 (C-6, 8), 119.5 (C-5a), 117.5 (C-7), 114.3* (C-2'), 113.8* (C-1'), 112.3 (C-9), 56.9 (C-3a), 48.2 (C-1), 40.6 (C-5), 39.1 (C-4), 30.1 (C-3), $23.0(\mathrm{C}-2), 21.7\left(\mathrm{CH}_{3}\right)$. HRMS (ESI+) $\mathrm{m} / z$ calcd. for $\mathrm{C}_{15} \mathrm{H}_{16} \mathrm{~N}_{3}[\mathrm{M}+\mathrm{H}]^{+} 238.1339$, found 238.1349 .

cis-( \pm )-6-Methyl-1H-2,3,4,4a,5,6-hexahydropyrido[1,2-a]quinoline-5,5-dicarbonitrile (5c). ${ }^{33}$

Following method C1, the title compound was isolated. (1. step) To a mixture of 2-(piperidino)acetophenone $(6.55 \mathrm{~g}, 32.30 \mathrm{mmol})$ in $40 \mathrm{~mL}$ water, malononitrile $(2.13 \mathrm{~g}$, $32.30 \mathrm{mmol}$ ) was added. The reaction mixture was irradiated at $100{ }^{\circ} \mathrm{C}$ for 12 minutes, then $(2$. 
step) to the reaction mixture trifluoroacetic acide was added and it was irradiated at $170{ }^{\circ} \mathrm{C}$ for $5 \mathrm{~min}$. The ratio of the diastereomers in the crude product by NMR: only cis isomer was formed. The crude product was crystallized from $\mathrm{MeOH}$ (distilled from $\mathrm{Na}$ and $\mathrm{P}_{2} \mathrm{O}_{5}$, dried over $3 \AA$ molecular sieves). White crystals $(4.88 \mathrm{~g}, 60 \%)$ mp $141.0-141.6{ }^{\circ} \mathrm{C}(\mathrm{MeOH}) .{ }^{1} \mathrm{H} \mathrm{NMR}$ : (600 MHz, chloroform- $d$ ): $7.23-7.18(2 \mathrm{H}, \mathrm{m}, \mathrm{H}-7,9), 6.93(1 \mathrm{H}, \mathrm{dm}, J 8 \mathrm{~Hz}, \mathrm{H}-10), 6.87-6.85$ $(1 \mathrm{H}, \mathrm{m}, \mathrm{H}-8), 4.01-3.95\left(1 \mathrm{H}, \mathrm{m}, \mathrm{H}_{\mathrm{x}}-1\right), 3.53-3.52(1 \mathrm{H}, \mathrm{m}, \mathrm{H}-6), 3.35(1 \mathrm{H}, \mathrm{dm}, J 11.5$ and $3.0 \mathrm{~Hz}$, $\mathrm{H}-4 \mathrm{a}), 2.70-2.68\left(1 \mathrm{H}, \mathrm{m}, \mathrm{H}_{\mathrm{y}}-1\right), 2.39-2.36\left(1 \mathrm{H}, \mathrm{m}, \mathrm{H}_{\mathrm{x}}-4\right), 2.02-2.00\left(1 \mathrm{H}, \mathrm{m}, \mathrm{H}_{\mathrm{x}}-3\right), 1.91-$ $1.88\left(1 \mathrm{H}, \mathrm{m}, \mathrm{H}_{\mathrm{x}}-2\right), 1.81-1.79\left(1 \mathrm{H}, \mathrm{m}, \mathrm{H}_{\mathrm{y}}-4\right), 1.77\left(3 \mathrm{H}, \mathrm{d}, J 7.0 \mathrm{~Hz}, \mathrm{CH}_{3}\right), 1.75-1.73(1 \mathrm{H}, \mathrm{m}$, $\left.\mathrm{H}_{\mathrm{y}}-2\right), 1.47-1.46\left(1 \mathrm{H}, \mathrm{m}, \mathrm{H}_{\mathrm{y}}-3\right)$; ${ }^{13} \mathrm{C}$ NMR: (150 MHz, chloroform- $d$ ): $144.6(\mathrm{C}-10 \mathrm{a}), 128.9$ (C9), 127.0 (C-7), 121.4 (C-6a), 119.6 (C-8), 115.1* (C-1'), 114.0 (C-10), 112.3* (C-2'), 60.2 (C4a), 48.1 (C-1), 46.2 (C-5), 40.0 (C-6), 30.0 (C-4), 24.8 (C-2), 22.8 (C-3), $16.6\left(\mathrm{CH}_{3}\right)$. Anal. calcd. for $\mathrm{C}_{16} \mathrm{H}_{17} \mathrm{~N}_{3}$ (251.33): C, 76.46\%; H, 6.82\%; N, 16.72\%. Found: C, 76.11\%; H, 7.01\%; N, $16.36 \%$. HRMS (ESI+) $m / z$ calcd. for $\mathrm{C}_{16} \mathrm{H}_{18} \mathrm{~N}_{3}[\mathrm{M}+\mathrm{H}]^{+} 252.1495$, found 252.1505 .

Following method C2, the title compound was isolated. The vinyl precursor $(0.20 \mathrm{~g}, 0.80 \mathrm{mmol})$ was irradiated at $180{ }^{\circ} \mathrm{C}$ for 10 minutes. The ratio of the diastereomers in the crude product by NMR: cis/trans $92: 8$. The crude product was purified by column chromatography (toluene). Pale yellow crystals $(0.14 \mathrm{~g}, 70 \%)$. mp $131.3-133.1{ }^{\circ} \mathrm{C}$. We were not able to isolate the trans isomer. ( \pm )-1-Methyl-4-phenyl-1,2,3,4-tetrahydroquinoline-3,3-dicarbonitrile (6a). Following method C2, the title compound was isolated. The vinyl precursor $(1.33 \mathrm{~g}, 4.86 \mathrm{mmol})$ was irradiated at $180^{\circ} \mathrm{C}$ for 1.5 hours. After transferring from the vial, to the reaction mixture ethyl acetate $(20 \mathrm{~mL})$ and water $(20 \mathrm{~mL})$ were added, then the water phase was extracted with ethyl acetate $(2 \times 20 \mathrm{~mL})$. The organic phase was dried over $\mathrm{MgSO}_{4}$ and evaporated under reduced pressure. The crude product was purified by column chromatography ( $n$-hexane/EtOAc 8:1). Yellow crystals $(0.87 \mathrm{~g}, 67 \%)$. mp 120.8-121.4 ${ }^{\circ} \mathrm{C} .{ }^{1} \mathrm{H}$ NMR: $(400 \mathrm{MHz}$, chloroform- $d$ ): 7.40-7.38 (3H, m, H-3', 4', 5'), $7.29-7.22$ (3H, m, 2', 6', 7), $6.84-6.79$ (2H, m, H-5, 8), $6.74-6.70$ (1H, m, H-6), 4.65 (1H, s, H-4), $3.81\left(1 \mathrm{H}, \mathrm{d}, J 11.5 \mathrm{~Hz}, \mathrm{H}_{\mathrm{x}}-2\right), 3.80\left(1 \mathrm{H}, \mathrm{d}, J 11.5 \mathrm{~Hz}, \mathrm{H}_{\mathrm{y}}-2\right), 3.14$ (3H, s, $\left.\mathrm{NCH}_{3}\right) ;{ }^{13} \mathrm{C}$ NMR: (100 MHz, chloroform- $d$ ): 144.0 (C-8a), 137.4 (C-1'), 130.3 (C-5), 130.2 (C2', 6’), 129.3 (C-7), 129.0 (C-4'), 128.8 (C-3', 5'), 118.6 (C-6), 118.4 (C-4a), 114.5 (C-1”), 113.4 (C-2”), 112.4 (C-8), $54.6(\mathrm{C}-2), 51.3(\mathrm{C}-4), 39.7\left(\mathrm{CH}_{3}\right), 37.5(\mathrm{C}-3)$. Anal. calcd. for $\mathrm{C}_{18} \mathrm{H}_{15} \mathrm{~N}_{3}$ (273.33): C, 79.10\%; H, 5.53\%; N, 15.37\%. Found: C, 78.71\%; H, 5.52\%; N, 15.17\%. HRMS: calcd for $\mathrm{C}_{18} \mathrm{H}_{16} \mathrm{~N}_{3}[\mathrm{M}+\mathrm{H}]^{+} 274.1339$, found 274.1333 .

cis-( \pm )-5-Phenyl-1,2,3,3a,4,5-hexahydropyrrolo[1,2-a]quinoline-4,4-dicarbonitrile (6b cis) and trans-( \pm )-5-Phenyl-1,2,3,3a,4,5-hexahydropyrrolo[1,2-a]quinoline-4,4-dicarbonitrile (6b trans). Following method B2, the title compound ( $6 \mathbf{b}$ cis) was isolated. To a mixture of malononitrile $(1.31 \mathrm{~g}, 19.89 \mathrm{mmol}) \quad$ in $i$-PrOH $(70 \mathrm{~mL})$, phenyl[2-(pyrrolidin-1yl)phenyl]methanone $(5.00 \mathrm{~g}, 19.89 \mathrm{mmol})$ and $\mathrm{Ti}(\mathrm{O}-i-\mathrm{Pr})_{4}(5.65 \mathrm{~g}, 19.89 \mathrm{mmol}, 5.88 \mathrm{~mL})$ were added. The dark red reaction mixture was stirred at $80{ }^{\circ} \mathrm{C}$ for 96 hours. The ratio of the diastereomers in the crude product was determined by NMR: cis/trans 92:8. The crude product was purified by column chromatography (toluene) and washed with diethyl ether to afford the pure cis isomer. Beige crystals (1.36 g, 35\%). mp 164.7-167.2 ${ }^{\circ} \mathrm{C} .{ }^{1} \mathrm{H}$ NMR: (600 MHz, chloroform- $d$ ): 
$7.48-7.41$ (5H, m, H-2', 3', 4', 5', 6') $7.25-7.20$ (1H, m, H-8), 6.71 (1H, dm, J 8.1 Hz, H-6), $4.59(1 \mathrm{H}, \mathrm{s}, \mathrm{H}-5), 4.08(1 \mathrm{H}, \mathrm{dd}, J$ 8.3, $6.2 \mathrm{~Hz}, \mathrm{H}-3 \mathrm{a}), 3.58\left(1 \mathrm{H}, \mathrm{m}, \mathrm{H}_{\mathrm{x}}-1\right) 3.52\left(1 \mathrm{H}, \mathrm{m}, \mathrm{H}_{\mathrm{y}}-1\right), 2.55$ $\left(1 \mathrm{H}, \mathrm{m}, \mathrm{H}_{\mathrm{x}}-3\right), 2.31\left(1 \mathrm{H}, \mathrm{m}, \mathrm{H}_{\mathrm{x}}-2\right), 2.28\left(1 \mathrm{H}, \mathrm{m}, \mathrm{H}_{\mathrm{y}}-3\right), 2.10\left(1 \mathrm{H}, \mathrm{m}, \mathrm{H}_{\mathrm{y}}-2\right) ;{ }^{13} \mathrm{C}$ NMR: $(150 \mathrm{MHz}$, chloroform- $d$ ): 142.7 (C-9a), 136.2 (C-1'), 129.6 (C-6), 129.3 (C-8), 129.2 (C-2', 6'), 128.9 (C4'), 128.5 (C-3', 5'), 118.1 (C-5a), 117.3 (C-7), 114.5* (C-2”), 112.6* (C-1”), 112.2 (C-9), 63.7 (C-3a), 53.5 (C-5), 47.9 (C-1), 43.3 (C-4), 30.2 (C-3), 22.7 (C-2). Anal. calcd. for $\mathrm{C}_{20} \mathrm{H}_{17} \mathrm{~N}_{3}$ (299.37): C, 80.24\%; H, 5.72\%; N, 14.04\%. Found: C, 80.40\%; H, 5.68\%; N, 14.16\%. HRMS (ESI+) $m / z$ calcd. for $\mathrm{C}_{20} \mathrm{H}_{18} \mathrm{~N}_{3}[\mathrm{M}+\mathrm{H}]^{+} 300.1501$, found 300.1501 .

Following method C2, the title compound (6b trans) was isolated. The vinyl precursor $(0.20 \mathrm{~g}$, $0.67 \mathrm{mmol}$ ) was irradiated at $150^{\circ} \mathrm{C}$ for 30 minutes. The ratio of the diastereomers in the crude product was determined by NMR: cis/trans $82: 18$. Beige crystals $(0.16 \mathrm{~g}, 82 \%$ overall yield of the crude product). The two diastereomers were separated by preparative HPLC (Teknokroma Nucleosil $100 \mathrm{C} 1810 \mu \mathrm{m} 25 \mathrm{~cm} \times 1 \mathrm{~mm}$; mobile phase composition: A/B 50:50 (A = methanol/water $3: 7, \mathrm{~B}=$ acetonitrile); flow rate: $3 \mathrm{~mL} / \mathrm{min}$ ). Beige crystals (trans isomer). $\mathrm{mp}$ 130.7 - $131.7^{\circ} \mathrm{C} .{ }^{1} \mathrm{H}$ NMR: (500 MHz, chloroform- $d$ ): $7.38-7.11\left(5 \mathrm{H}, \mathrm{m}, \mathrm{H}-2^{\prime}, 3^{\prime}, 4^{\prime}, 5^{\prime}, 6^{\prime}\right)$, $7.28-7.25(1 \mathrm{H}, \mathrm{m}, \mathrm{H}-8), 7.02(1 \mathrm{H}, \mathrm{dm}, J 7.5 \mathrm{~Hz}, \mathrm{H}-6), 6.74-6.72(1 \mathrm{H}, \mathrm{m}, \mathrm{H}-7), 6.73(1 \mathrm{H}, \mathrm{dm}$, $J 6.5 \mathrm{~Hz}, \mathrm{H}-9), 4.74(1 \mathrm{H}, \mathrm{s}, \mathrm{H}-5), 3.77(1 \mathrm{H}, \mathrm{dd}, J 9.0$ and $5.5 \mathrm{~Hz}, \mathrm{H}-3 \mathrm{a}), 3.73\left(1 \mathrm{H}, \mathrm{m}, \mathrm{H}_{\mathrm{x}}-1\right), 3.46$ (1H, m, Hy-1), $2.37\left(1 \mathrm{H}, \mathrm{m}, \mathrm{H}_{\mathrm{x}}-3\right), 2.28\left(1 \mathrm{H}, \mathrm{m}, \mathrm{H}_{\mathrm{x}}-2\right), 2.16\left(1 \mathrm{H}, \mathrm{m}, \mathrm{H}_{\mathrm{y}}-3\right), 2.08\left(1 \mathrm{H}, \mathrm{m}, \mathrm{H}_{\mathrm{y}}-2\right)$; ${ }^{13} \mathrm{C}$ NMR: (125 MHz, chloroform- $d$ ): 142.2 (C-9a), 137.9 (C-1'), 130.3 (C-2', 6'), 130.2 (C-6), 129.6 (C-8), 128.7 (C-4'), 128.6 (C-3', 5'), 117.7 (C-7), 116.7 (C-5a), 114.0 (C-2”), 113.9 (C-1”), 112.2 (C-9), 57.1 (C-3a), 51.1 (C-5), 48.7 (C-1), 39.7 (C-4), 30.0 (C-3), 23.1 (C-2). HRMS (ESI+) $\mathrm{m} / z$ calcd. for $\mathrm{C}_{20} \mathrm{H}_{18} \mathrm{~N}_{3}[\mathrm{M}+\mathrm{H}]^{+} 300.1494$, found 300.1503 .

cis-( \pm )-6-Phenyl-1H-2,3,4,4a,5,6-hexahydropyrido[1,2-a]quinoline-5,5-dicarbonitrile (6c cis) and trans-( \pm -6-Phenyl-1H-2,3,4,4a,5,6-hexahydropyrido[1,2-a]quinoline-5,5-dicarbonitrile (6c trans). Following method $\mathbf{C 2}$, the title compound (6c cis) was isolated. The vinyl precursor $(0.20 \mathrm{~g}, 0.64 \mathrm{mmol})$ was irradiated at $190{ }^{\circ} \mathrm{C}$ for 10 minutes. Beige crystals $(0.19 \mathrm{~g}, 95 \%$ overall yield of the crude product). The ratio of the diastereomers in the crude product was determined by NMR: cis/trans 71:29 and by HPLC: $\mathrm{CH}_{3} \mathrm{CN} / \mathrm{H}_{2} \mathrm{O}$ 65:35, $\mathrm{t}_{\mathrm{R}}: 19.7$ and $18.8 \mathrm{~min}, 70 \%$ and 30\%. The two diastereomers were separated by preparative HPLC (Teknokroma Nucleosil $100 \mathrm{C} 18$ $10 \mu \mathrm{m} 25 \mathrm{~cm} \times 1 \mathrm{~mm}$; mobile phase composition: A/B 40:60 (A = methanol/water 3:7, $\mathrm{B}=$ acetonitrile); flow rate: $3 \mathrm{~mL} / \mathrm{min}$ ). Beige powder (cis isomer). mp 199-202 ${ }^{\circ} \mathrm{C} .{ }^{1} \mathrm{H} \mathrm{NMR}$ : (400 MHz, chloroform- $d$ ): 7.44 - 7.43 (5H, m, H-2', 3', 4', 5', 6'), 7.26 - 7.21 (1H, m, H-9), 6.99 $(1 \mathrm{H}, \mathrm{dm}, J 8.5 \mathrm{~Hz}, \mathrm{H}-10), 6.74-6.72(2 \mathrm{H}, \mathrm{m}, \mathrm{H}-7,8), 4.68(1 \mathrm{H}, \mathrm{s}, \mathrm{H}-6), 4.03$ (1H, dm, J $11.9 \mathrm{~Hz}$, $\left.\mathrm{H}_{\mathrm{x}}-1\right), 3.50(1 \mathrm{H}, \mathrm{dd}, J 11.5$ and $3.4 \mathrm{~Hz}, \mathrm{H}-4 \mathrm{a}), 2.71\left(1 \mathrm{H}, \mathrm{td}, J 12.4\right.$ and $\left.3.3 \mathrm{~Hz}, \mathrm{H}_{\mathrm{y}}-1\right), 2.44-2.41$ $\left(1 \mathrm{H}, \mathrm{m}, \mathrm{H}_{\mathrm{x}}-4\right), 2.01-1.90\left(1 \mathrm{H}, \mathrm{m}, \mathrm{H}_{\mathrm{x}}-3\right), 1.89-1.81\left(1 \mathrm{H}, \mathrm{m}, \mathrm{H}_{\mathrm{y}}-4\right), 1.79-1.76\left(1 \mathrm{H}, \mathrm{m}, \mathrm{H}_{\mathrm{x}}-2\right)$, 1.46 - 1.36 (2H, m, $\left.\mathrm{H}_{\mathrm{y}}-2,3\right)$; ${ }^{13} \mathrm{C}$ NMR: (100 MHz, chloroform- $d$ ): 145.9 (C-10a), 136.7 (C-1'), 130.3 (C-3', 5'), 130.0 (C-7), 129.2 (C-4'), 129.1 (C-9), 128.8 (C-2', 6'), 120.7 (C-6a), 119.4 (C8), 114.3 (C-10), 114.0* (C-2”), 112.9* (C-1”), 60.7 (C-4a), 52.7 (C-6), 48.0 (C-1), 47.2 (C-5), 30.0 (C-4), 24.9 (C-2), 22.4 (C-3). Anal. calcd. for $\mathrm{C}_{21} \mathrm{H}_{19} \mathrm{~N}_{3}$ (313.40): C, 80.48\%; H, 6.11\%; N, 
13.41\%. Found: C, 80.47\%; H, 6.16\%; N, 13.19\%. HRMS (ESI +$) m / z$ calcd. for $\mathrm{C}_{21} \mathrm{H}_{20} \mathrm{~N}_{3}[\mathrm{M}+\mathrm{H}]^{+}$ 314.1652 , found 314.1645 ; and,

Beige crystals (trans isomer). mp 54.6-61.9 ${ }^{\circ} \mathrm{C} .{ }^{1} \mathrm{H}$ NMR: $(500 \mathrm{MHz}$, chloroform- $d$ ): $7.42-7.14$ (5H, m, H-2', 3', 4', 5', 6'), 7.25 (1H, m, H-9), 7.04 (1H, dm, J 8.5 Hz, H-10), 6.89 (1H, dm, $J$ $7.5 \mathrm{~Hz}, \mathrm{H}-7), 6.76(1 \mathrm{H}, \mathrm{m}, \mathrm{H}-8), 4.64(1 \mathrm{H}, \mathrm{s}, \mathrm{H}-6), 4.20\left(1 \mathrm{H}, \mathrm{m}, \mathrm{H}_{\mathrm{x}}-1\right), 3.29(1 \mathrm{H}, \mathrm{dd}, J 11.0$ and $2.5 \mathrm{~Hz}, \mathrm{H}-4 \mathrm{a}), 2.86\left(1 \mathrm{H}, \mathrm{m}, \mathrm{H}_{\mathrm{y}}-1\right), 2.14-1.42\left(6 \mathrm{H}, \mathrm{m}, \mathrm{H}_{\mathrm{x}, \mathrm{y}}-2,3,4\right) ;{ }^{13} \mathrm{C} \mathrm{NMR}$ : (125 MHz, chloroform- $d$ ): 144.3 (C-10a), 138.0 (C-1'), 130.8 (C-7), 130.6 (C-2', 6'), 129.5 (C-9), 128.8 (C4'), 128.6 (C-3', 5'), 119.4 (C-8), 118.8 (C-6a), 114.3* (C-2”), 114.2 (C-10), 113.7* (C-1"), 55.7 (C-4a), 49.8 (C-6), 48.8 (C-1), 43.5 (C-5), 28.8 (C-4), 24.5 (C-2), 23.5 (C-3). HRMS (ESI+) m/z calcd. for $\mathrm{C}_{21} \mathrm{H}_{20} \mathrm{~N}_{3}[\mathrm{M}+\mathrm{H}]^{+} 314.1652$, found 314.1657 .

General procedure for the radical decyanation (method D). The dinitrile compound (pure diastereomer) (1 eq) was dissolved in dry toluene $(80 \mathrm{~mL})$ (distilled from $\mathrm{LiAlH}_{4}$ prior to use) a pale yellow solution was formed. After addition of azobisisobutyronitrile (AIBN) (0.2 eq) and tributyltinhydride ( 2 eq) at $0{ }^{\circ} \mathrm{C}$, the mixture was stirred for the time indicated below at $80{ }^{\circ} \mathrm{C}$ (oil bath). After cooling, an aliquot was taken for the analysis of the diastereomers. To the pale yellow or colorless reaction mixture 1,8-diazabicyclo[5.4.0]undec-7-ene (DBU) (1.3 eq) was added and stirred for $30 \mathrm{~min}$. The mixture was filtered through a silica gel plug and the solvent evaporated in vacuum. The crude product was purified as described below.

The ratio of the diastereomers in the crude product was determined by HPLC (Gemini NX C18 RP $25 \mathrm{~cm} \times 4.6 \mathrm{~mm} 5 \mu \mathrm{m}$ column, $\mathrm{CH}_{3} \mathrm{CN} / \mathrm{H}_{2} \mathrm{O} 80: 20$ ) or ${ }^{1} \mathrm{H} \mathrm{NMR}$.

cis-( \pm )-1,4-Dimethyl-1,2,3,4-tetrahydroquinoline-3-carbonitrile (9a cis). Following method D, the title compound was isolated. To a mixture of the dinitrile derivative $(0.77 \mathrm{~g}, 3.63 \mathrm{mmol})$ in $20 \mathrm{~mL}$ of toluene, AIBN $(0.12 \mathrm{~g}, 0.73 \mathrm{mmol}, 0.2 \mathrm{eq})$ and tributyltinhydride $(2.9 \mathrm{~mL}, 3.17 \mathrm{~g}$, $10.87 \mathrm{mmol}, 2 \mathrm{eq}$ ) were added at $0{ }^{\circ} \mathrm{C}$, the reaction mixture was stirred at $90-100{ }^{\circ} \mathrm{C}$ for 1.5 hours. Diastereomeric ratio in the crude product (HPLC): 67:33 cis/trans. Overall yield of the diastereomers is $85 \%$. The diastereomers were separated by preparative HPLC (see Supplementary Material). The determination of the relative configuration in these compounds were not possible, due to overlap of the relevant aliphatic protons. However, the Boc derivative (8a) proved to be cis diastereoisomer, based on NOE interactions and analysis of the vicinal coupling constants. Since under the reaction conditions of Boc formation the configuration of the carbon atoms do not change, the relative configuration in this compound is also cis. White crystals. mp 88.0-89.5 ${ }^{\circ} \mathrm{C}$. ${ }^{1} \mathrm{H}$ NMR (500 MHz, chloroform- $d$ ): 7.15 - 7.14 (1H, m, H-7), 7.06 - 7.04 (1H, m, H-5), 6.73 $6.71(1 \mathrm{H}, \mathrm{m}, \mathrm{H}-6), 6.64(1 \mathrm{H}, \mathrm{dm}, J 7.5 \mathrm{~Hz}, \mathrm{H}-8), 3.49-3.45\left(2 \mathrm{H}, \mathrm{m}, \mathrm{H}_{\mathrm{x}, \mathrm{y}}-2\right), 3.22-3.20(2 \mathrm{H}, \mathrm{m}$, $\mathrm{H}-3), 2.95\left(3 \mathrm{H}, \mathrm{s}, \mathrm{NCH}_{3}\right), 1.45\left(3 \mathrm{H}, \mathrm{d}, J 7.0 \mathrm{~Hz}, \mathrm{CH}_{3}\right) ;{ }^{13} \mathrm{C}$ NMR $(125 \mathrm{MHz}$, chloroform- $d$ ): 144.9 (C-8a), 128.9 (C-5), 128.8 (C-7), 124.6 (C-4a), $120.1(\mathrm{CN}), 118.0$ (C-6), 112.2 (C-8), 49.6 (C-2), $39.6\left(\mathrm{NCH}_{3}\right), 33.7(\mathrm{C}-4), 31.7(\mathrm{C}-3), 20.6\left(\mathrm{CH}_{3}\right)$. Anal. calcd (\%) for $\mathrm{C}_{12} \mathrm{H}_{14} \mathrm{~N}_{2}$ (186.25): C 77.38; $\mathrm{H}$ 7.58; N 15.04. Found: C 77.33; H 7.67; N 15.14. HRMS (ESI+) $m / z$ calcd. for $\mathrm{C}_{12} \mathrm{H}_{15} \mathrm{~N}_{2}[\mathrm{M}+\mathrm{H}]^{+}$ 187.1230, found 187.1225. 
cis-cis-( \pm )-5-Methyl-1,2,3,3a,4,5-hexahydropyrrolo[1,2-a]quinoline-4-carbonitrile (9b cis-cis) and cis-trans-( \pm )-5-Methyl-1,2,3,3a,4,5-hexahydropyrrolo[1,2-a]quinoline-4carbonitrile (9b cis-trans). Following method $\mathrm{D}$, the title compounds were isolated. To a mixture of the dinitrile derivative (cis isomer) $(4.04 \mathrm{~g}, 17.04 \mathrm{mmol})$ in $70 \mathrm{~mL}$ of toluene AIBN $(0.56 \mathrm{~g}$, $34.10 \mathrm{mmol}, 0.2 \mathrm{eq})$ and tributyltinhydride $(9.18 \mathrm{~mL}, 34.08 \mathrm{mmol}, 2 \mathrm{eq})$ were added at $0{ }^{\circ} \mathrm{C}$, the reaction mixture was stirred for at $90{ }^{\circ} \mathrm{C}$ for 24 hours. Diastereomeric ratio in the crude product (HPLC): 58:42 cis-cis/cis-trans. The two diastereomers were separated by column chromatography ( $n$-hexane/EtOAc 4:1).

(9b cis-cis) Off-white crystals (1.10 g, 31\%). mp 136.4-137.4 ${ }^{\circ} \mathrm{C}$ (n-hexane/EtOAc 6.5:1). ${ }^{1} \mathrm{H}$ NMR (500 MHz, chloroform- $d$ ): 7.14 - 7.12 (2H, m, H-6, 8), 6.68 - 6.67 (1H, m, H-7), 6.47 $(1 \mathrm{H}, \mathrm{dm}, J 8.5 \mathrm{~Hz}, \mathrm{H}-9), 3.73-3.70(1 \mathrm{H}, \mathrm{m}, \mathrm{H}-3 \mathrm{a}), 3.40-3.38\left(1 \mathrm{H}, \mathrm{m}, \mathrm{H}_{\mathrm{x}}-1\right), 3.34-3.33(1 \mathrm{H}$, m, $\left.\mathrm{H}_{\mathrm{y}}-1\right), 3.24-3.23(1 \mathrm{H}, \mathrm{m}, \mathrm{H}-5), 3.13(1 \mathrm{H}, \mathrm{dd}, J 4.5 \mathrm{~Hz}, \mathrm{H}-4), 2.19-2.17$ (2H, m, $\left.\mathrm{H}_{\mathrm{x}}-2,3\right), 2.00$ $-1.97\left(2 \mathrm{H}, \mathrm{m}, \mathrm{H}_{\mathrm{y}}-2,3\right), 1.57\left(3 \mathrm{H}, \mathrm{d}, J 7.0 \mathrm{~Hz}, \mathrm{CH}_{3}\right) ;{ }^{13} \mathrm{C}$ NMR (125 MHz, chloroform-d): 143.9 (C-9a), 128.9 (C-8), 127.0 (C-6), 121.9 (C-5a), $118.4(C \mathrm{~N}), 116.8$ (C-7), 111.4 (C-9), 59.0 (C-3a), $47.9(\mathrm{C}-1), 37.7(\mathrm{C}-4), 34.8(\mathrm{C}-5), 31.3(\mathrm{C}-3), 24.0(\mathrm{C}-2), 18.4\left(\mathrm{CH}_{3}\right)$. Anal. calcd (\%) for $\mathrm{C}_{14} \mathrm{H}_{16} \mathrm{~N}_{2}$ (212.29): C 79.21; H 7.60; N 13.20. Found: C 79.35; H 7.64; N 13.24. HRMS (ESI+) $\mathrm{m} / z$ calcd. for $\mathrm{C}_{14} \mathrm{H}_{17} \mathrm{~N}_{2}[\mathrm{M}+\mathrm{H}]^{+}$213.1386, found 213.1392.

(9b cis-trans) White crystals $(0.82 \mathrm{~g}, 22 \%) . \mathrm{mp} 142.8-143.5^{\circ} \mathrm{C}$ ( $n$-hexane). ${ }^{1} \mathrm{H}$ NMR $(500 \mathrm{MHz}$, chloroform- $d$ ): $7.17(1 \mathrm{H}, \mathrm{dm}, J 7.5 \mathrm{~Hz}, \mathrm{H}-6), 7.14-7.13(1 \mathrm{H}, \mathrm{m}, \mathrm{H}-8), 6.70$ - 6.69 (1H, m, H-7), 6.45 (1H, dm, J 9.0 Hz, H-9), 3.63 - 3.62 (1H, m, H-3a), $3.40-3.39$ (1H, m, Hx-1), $3.29-3.27$ $\left(1 \mathrm{H}, \mathrm{m}, \mathrm{H}_{\mathrm{y}}-1\right), 3.17-3.16(1 \mathrm{H}, \mathrm{m}, \mathrm{H}-5), 2.47-2.44\left(1 \mathrm{H}, \mathrm{m}, \mathrm{H}_{\mathrm{x}}-3\right), 2.35(1 \mathrm{H}, \mathrm{dd}, J 11.5$ and $10.4 \mathrm{~Hz}, \mathrm{H}-4), 2.14$ - $2.11\left(1 \mathrm{H}, \mathrm{m}, \mathrm{H}_{\mathrm{x}}-2\right), 1.99$-1.97 (1H, m, $\left.\mathrm{H}_{\mathrm{y}}-2\right), 1.70-1.67$ (1H, m, $\left.\mathrm{H}_{\mathrm{y}}-3\right), 1.58$ (3H, d, J 6.5 Hz, CH3); ${ }^{13} \mathrm{C}$ NMR (125 MHz, chloroform- $d$ ): 143.9 (C-9a), 128.8 (C-8), 127.1 (C6), 123.3 (C-5a), $121.3(\mathrm{CN}), 117.0$ (C-7), 111.6 (C-9), 59.8 (C-3a), 48.4 (C-1), 40.3 (C-4), 35.9 (C-5), 33.1 (C-3), $23.8(\mathrm{C}-2), 18.9\left(\mathrm{CH}_{3}\right)$. Anal. calcd (\%) for $\mathrm{C}_{14} \mathrm{H}_{16} \mathrm{~N}_{2}(212.29)$ : C 79.21; $\mathrm{H}$ 7.60; $\mathrm{N}$ 13.20. Found: C 79.45; H 7.64; N 13.25. HRMS (ESI +$) m / z$ calcd. for $\mathrm{C}_{14} \mathrm{H}_{17} \mathrm{~N}_{2}[\mathrm{M}+\mathrm{H}]^{+}$ 213.1386, found 213.1390 .

cis-cis-( \pm -6-Methyl-1H-2,3,4,4a,5,6-hexahydropyrido[1,2-a]quinoline-5-carbonitrile (9c cis-cis) and cis-trans-( \pm )-6-Methyl-1H-2,3,4,4a,5,6-hexahydropyrido[1,2-a]quinoline-5carbonitrile (9c cis-trans). Following method D, the title compounds were isolated. To a mixture of the dinitrile derivative (cis isomer) $(4.86 \mathrm{~g}, 19.37 \mathrm{mmol})$ in $80 \mathrm{~mL}$ of toluene AIBN (0.2 eq) and tributyltinhydride ( $2 \mathrm{eq}$ ) were added at $0{ }^{\circ} \mathrm{C}$, the reaction mixture was stirred for 24 hours. Diastereomeric product ratio in the crude product (HPLC): 72:28 cis-cis/cis-trans. The two diastereomers were separated by column chromatography ( $n$-hexane/EtOAc 4:1).

(9c cis-cis) White crystals (2.50 g, 55\%). mp 181.6-183.0 ${ }^{\circ} \mathrm{C}$ ( $n$-hexane/EtOAc 1:1.1). ${ }^{1} \mathrm{H}$ NMR: (500 MHz, chloroform- $d$ ): $7.15-7.11(2 \mathrm{H}, \mathrm{m}, \mathrm{H}-7,9), 6.89-6.87(1 \mathrm{H}, \mathrm{dm}, J 10.5 \mathrm{~Hz}, \mathrm{H}-10), 6.76$ - $6.74(1 \mathrm{H}, \mathrm{m}, \mathrm{H}-8), 3.98\left(1 \mathrm{H}, \mathrm{dm}, J 15.5 \mathrm{~Hz}, \mathrm{H}_{\mathrm{x}}-1\right), 3.30-3.25(1 \mathrm{H}, \mathrm{m}, \mathrm{H}-6), 3.13-3.09(1 \mathrm{H}$, m, H-4a), 3.04 - 3.02 (1H, m, H-5), $2.65-2.59$ (1H, m, Hy $\left.\mathrm{H}_{\mathrm{y}} 1\right), 1.91-1.89$ (1H, m, $\left.\mathrm{H}_{\mathrm{x}}-3\right), 1.84$ $1.71\left(4 \mathrm{H}, \mathrm{m}, \mathrm{H}_{\mathrm{x}, \mathrm{y}}-2,4\right), 1.52\left(3 \mathrm{H}, \mathrm{d}, J 12 \mathrm{~Hz}, \mathrm{CH}_{3}\right), 1.41-1.39\left(1 \mathrm{H}, \mathrm{m}, \mathrm{H}_{\mathrm{y}}-3\right) ;{ }^{13} \mathrm{C} \mathrm{NMR}$ : (125 MHz, chloroform- $d$ ): 146.5 (C-10a), 128.6* (C-9), 127.5* (C-7), 125.4 (C-6a), 119.3 (C-8), 
$119.0(\mathrm{CN}), 114.4$ (C-10), 57.9 (C-4a), 48.9 (C-1), 41.7 (C-5), 34.1 (C-6), 32.2 (C-4), 26.1 (C-2), $24.2(\mathrm{C}-3), 18.6\left(\mathrm{CH}_{3}\right)$. Anal. calcd (\%) for $\mathrm{C}_{15} \mathrm{H}_{18} \mathrm{~N}_{2}(226.32)$ : $\mathrm{C} 79.61 ; \mathrm{H}$ 8.02; $\mathrm{N}$ 12.38. Found: C 79.75; H 8.12; N 11.98. HRMS (ESI+) $m / z$ calcd. for $\mathrm{C}_{15} \mathrm{H}_{19} \mathrm{~N}_{2}[\mathrm{M}+\mathrm{H}]^{+} 227.1543$, found 227.1538 .

(9c cis-trans) White crystals $(0.768 \mathrm{~g}, 17 \%)$. mp $144.0-144.5^{\circ} \mathrm{C} .{ }^{1} \mathrm{H}$ NMR: $(500 \mathrm{MHz}$, chloroform- $d$ ): $7.16(1 \mathrm{H}, \mathrm{m}, \mathrm{H}-7), 7.16-7.13(1 \mathrm{H}, \mathrm{m}, \mathrm{H}-9), 6.85(1 \mathrm{H}, \mathrm{dm}, J 8.5 \mathrm{~Hz}, \mathrm{H}-10), 6.80-$ $6.77(1 \mathrm{H}, \mathrm{m}, \mathrm{H}-8), 3.89\left(1 \mathrm{H}, \mathrm{dm}, J 8.4 \mathrm{~Hz}, \mathrm{H}_{\mathrm{x}}-1\right), 3.15(1 \mathrm{H}, \mathrm{m}, \mathrm{H}-6), 3.10$ (1H, m, H-4a), 2.67 $\left(1 \mathrm{H}, \mathrm{m}, \mathrm{H}_{\mathrm{y}}-1\right), 2.58(1 \mathrm{H}, \mathrm{m}, \mathrm{H}-5), 2.28\left(1 \mathrm{H}, \mathrm{m}, \mathrm{H}_{\mathrm{x}}-4\right), 1.90\left(1 \mathrm{H}, \mathrm{m}, \mathrm{H}_{\mathrm{x}}-3\right), 1.82\left(1 \mathrm{H}, \mathrm{m}, \mathrm{H}_{\mathrm{x}}-2\right), 1.62$ $\left(1 \mathrm{H}, \mathrm{m}, \mathrm{H}_{\mathrm{y}}-2\right), 1.54\left(3 \mathrm{H}, \mathrm{d}, J 4.8 \mathrm{~Hz}, \mathrm{CH}_{3}\right), 1.44\left(1 \mathrm{H}, \mathrm{m}, \mathrm{H}_{\mathrm{y}}-3\right), 1.38\left(1 \mathrm{H}, \mathrm{m}, \mathrm{H}_{\mathrm{y}}-4\right) ;{ }^{13} \mathrm{C} \mathrm{NMR}$ : (125 MHz, chloroform- $d$ ): 146.4 (C-10a), 128.5 (C-9), 127.4 (C-7), 126.6 (C-6a), $121.1(C \mathrm{~N})$, 119.3 (C-8), 114.2 (C-10), 58.3 (C-4a), 49.0 (C-1), 42.9 (C-5), 35.2 (C-6), 32.9 (C-4), 25.9 (C-2), $24.2(\mathrm{C}-3), 19.7\left(\mathrm{CH}_{3}\right)$. Anal. calcd (\%) for $\mathrm{C}_{15} \mathrm{H}_{18} \mathrm{~N}_{2}$ (226.32): C 79.61; H 8.02; N 12.38. Found: C 79.29; H 7.99; N 12.00. HRMS (ESI+) $\mathrm{m} / z$ calcd. for $\mathrm{C}_{15} \mathrm{H}_{19} \mathrm{~N}_{2}[\mathrm{M}+\mathrm{H}]^{+} 227.1543$, found 227.1532 .

cis-( \pm )-1-Methyl-4-phenyl-1,2,3,4-tetrahydroquinoline-3-carbonitrile (10a cis). Following method $\mathbf{D}$, the title compound was isolated. To a mixture of the dinitrile derivative $(1.03 \mathrm{~g}$, $3.73 \mathrm{mmol})$ in $25 \mathrm{~mL}$ of toluene AIBN $(0.11 \mathrm{~g}, 0.70 \mathrm{mmol}, 0.2 \mathrm{eq})$ and tributyltinhydride $(3.0 \mathrm{~mL}$, $3.26 \mathrm{~g}, 11.20 \mathrm{mmol}, 3 \mathrm{eq}$ ) were added at $0{ }^{\circ} \mathrm{C}$, the reaction mixture was stirred at $90{ }^{\circ} \mathrm{C}$ for 2 hours. Only cis isomer was formed as determined form the crude product by NMR. After the crystallisation white, bright crystals were obtained $(0.28 \mathrm{~g}, 30 \%) . \mathrm{mp} 117.3-120.0{ }^{\circ} \mathrm{C} .{ }^{1} \mathrm{H}$ NMR: (400 MHz, chloroform- $d$ ): $7.39-7.08$ (6H, m, H-7, 2', 3', 4', 5', 6'), $6.90-6.82(1 \mathrm{H}, \mathrm{dm}, J$ $7.3 \mathrm{~Hz}, \mathrm{H}-5), 6.78-6.70(1 \mathrm{H}, \mathrm{dm}, J 8.1 \mathrm{~Hz}, \mathrm{H}-8), 6.69-6.61(1 \mathrm{H}, \mathrm{m}, \mathrm{H}-6), 4.45-4.37(1 \mathrm{H}, \mathrm{m}$, $\mathrm{H}-4), 3.51-3.31$ (3H, m, $\left.\mathrm{H}_{\mathrm{x}, \mathrm{y}}-2, \mathrm{H}-3\right), 3.02\left(3 \mathrm{H}, \mathrm{s}, \mathrm{CH}_{3}\right) ;{ }^{13} \mathrm{C} \mathrm{NMR}$ : (100 MHz, chloroform- $d$ ): 145.1 (C-8a), 140.6 (C-1'), 130.0 (C-5), 129.7 (C-2', 6'), 128.6 (C-7), 128.4 (C-3', 5'), 127.6 (C4'), $121.0(\mathrm{C}-4 \mathrm{a}), 119.0(\mathrm{CN}), 117.3$ (C-6), $111.5(\mathrm{C}-8), 49.0(\mathrm{C}-2), 45.0(\mathrm{C}-4), 39.1\left(\mathrm{CH}_{3}\right), 31.9$ (C-3). Anal. calcd. for $\mathrm{C}_{17} \mathrm{H}_{16} \mathrm{~N}_{2}$ (248.33): C, 82.22\%; H, 6.49\%; N, 11.28\%. Found: C, 81.89\%; $\mathrm{H}, 6.50 \%$; N, 11.11\%. HRMS (ESI+) $m / z$ calcd. for $\mathrm{C}_{17} \mathrm{H}_{17} \mathrm{~N}_{2}[\mathrm{M}+\mathrm{H}]^{+} 249.1386$, found 249.1382 . cis-cis-( \pm )-5-Phenyl-1,2,3,3a,4,5-hexahydropyrrolo[1,2-a]quinoline-4-carbonitrile (10b cis-cis) and cis-trans-( \pm )-5-Phenyl-1,2,3,3a,4,5-hexahydropyrrolo[1,2-a]quinoline-4carbonitrile (10b cis-trans). Following method $\mathbf{D}$, the title compound (8b cis-trans) was isolated. To a mixture of the dinitrile derivative (cis isomer) $(2.28 \mathrm{~g}, 7.61 \mathrm{mmol})$ in $50 \mathrm{~mL}$ of toluene AIBN $(0.25 \mathrm{~g}, 1.52 \mathrm{mmol}, 0.2 \mathrm{eq})$ and tributyltinhydride $(6.1 \mathrm{~mL}, 6.64 \mathrm{~g}, 22.82 \mathrm{mmol}, 3 \mathrm{eq})$ were added at $0{ }^{\circ} \mathrm{C}$, the reaction mixture was stirred at $90{ }^{\circ} \mathrm{C}$ for 8 hours. Diastereomeric product ratio in the crude product (NMR): cis-cis/cis-trans 50:50. The cis-trans diastereomer was isolated by column chromatography ( $n$-hexane/EtOAc 8:1). White crystals $(0.34 \mathrm{~g}, 16 \%)$ mp 205.3-205.6 ${ }^{\circ} \mathrm{C}$. ${ }^{1} \mathrm{H}$ NMR: (400 MHz, chloroform- $d$ ): 7.39 - 7.30 (3H, m, H-3', 4', 5'), 7.26 - 7.21 (2H, m, H-2', 6'), $7.13-7.10$ (1H, m, H-8), 6.58 - 6.49 (3H, m, H-6, 7, 9), 4.28 (1H, d, J 11.8 Hz, H-5), 3.77 $3.70(1 \mathrm{H}, \mathrm{m}, \mathrm{H}-3 \mathrm{a}), 3.47-3.35\left(2 \mathrm{H}, \mathrm{m}, \mathrm{H}_{\mathrm{x}, \mathrm{y}}-1\right), 2.81(1 \mathrm{H}, \mathrm{dd}, J 11.8$ and $10.4 \mathrm{~Hz}, \mathrm{H}-4), 2.50-$ $2.44\left(1 \mathrm{H}, \mathrm{m}, \mathrm{H}_{\mathrm{x}}-3\right), 2.19-2.15\left(1 \mathrm{H}, \mathrm{m}, \mathrm{H}_{\mathrm{x}}-2\right), 2.07-1.99\left(1 \mathrm{H}, \mathrm{m}, \mathrm{H}_{\mathrm{y}}-2\right), 1.79-1.73\left(1 \mathrm{H}, \mathrm{m}, \mathrm{H}_{\mathrm{y}}-\right.$ 3); ${ }^{13} \mathrm{C}$ NMR: (100 MHz, chloroform- $d$ ): 143.7 (C-9a), 141.2 (C-1'), 129.7 (C-6), 129.03 (C-3', 
5'), 128.96 (C-2', 6'), 128.3 (C-8), 127.8 (C-4'), 122.3 (C-5a), $119.8(\mathrm{CN}), 116.4$ (C-7), 111.1 (C9), 48.5 (C-5), 47.6 (C-1), 40.7 (C-4), 32.3 (C-3), 23.0 (C-2). HRMS (ESI+) m/z calcd. for $\mathrm{C}_{19} \mathrm{H}_{19} \mathrm{~N}_{2}[\mathrm{M}+\mathrm{H}]^{+} 275.1543$, found 275.1541.

The cis-cis isomer was isolated by HPLC. Beige powder. mp $175.0-178.5^{\circ} \mathrm{C} .{ }^{1} \mathrm{H}$ NMR: (500 MHz, chloroform- $d$ ): 7.44 - 7.31 (5H, m, H-2', 3', 4', 5', 6'), 7.17 - 7.14 (1H, m, H-8), 6.72 $(1 \mathrm{H}, \mathrm{dm}, J 2.7 \mathrm{~Hz}, \mathrm{H}-6), 6.57-6.56(1 \mathrm{H}, \mathrm{m}, \mathrm{H}-7), 6.56-6.54(1 \mathrm{H}, \mathrm{m}, \mathrm{H}-9), 4.45$ (1H, d, J $5 \mathrm{~Hz}$, $\mathrm{H}-5), 3.90-3.87(1 \mathrm{H}, \mathrm{m}, \mathrm{H}-3 \mathrm{a}), 3.50-3.39\left(2 \mathrm{H}, \mathrm{m}, \mathrm{H}_{\mathrm{x}, \mathrm{y}}-1\right), 3.29(1 \mathrm{H}, \mathrm{dd}, J 4.9$ and $2.7 \mathrm{~Hz}, \mathrm{H}-4)$, $2.22-2.20\left(2 \mathrm{H}, \mathrm{m}, \mathrm{H}_{\mathrm{x}}-2,3\right), 2.09-2.07\left(1 \mathrm{H}, \mathrm{m}, \mathrm{H}_{\mathrm{y}}-3\right), 2.05-2.00\left(1 \mathrm{H}, \mathrm{m}, \mathrm{H}_{\mathrm{y}}-2\right) ;{ }^{13} \mathrm{C} \mathrm{NMR}$ : (125 MHz, chloroform- $d$ ): 144.0 (C- 9a), 140.2 (C-1'), 129.5 (C-2', 6'), 129.1 (C-6), 128.7 (C-4'), 128.5 (C-8), 127.9 (C-3', 5'), 119.9 (C-5a), $118.2(\mathrm{CN}), 116.0$ (C-7), 111.2 (C-9), 58.9 (C-3a), 47.6 (C-5), 47.1 (C-1), 38.2 (C-4), 30.5 (C-3), 23.2 (C-2). HRMS (ESI+) m/z calcd. for $\mathrm{C}_{19} \mathrm{H}_{19} \mathrm{~N}_{2}[\mathrm{M}+\mathrm{H}]^{+} 275.1543$, found 275.1545 .

cis-cis-( \pm )-6-Phenyl-1 H-2,3,4,4a,5,6-hexahydropyrido[1,2-a]quinoline-5-carbonitrile

(10c cis-cis). Following method D, the title compound was isolated. To a mixture of the dinitrile derivative (cis isomer) $(3.00 \mathrm{~g}, 9.57 \mathrm{mmol})$ in $60 \mathrm{~mL}$ of toluene $\mathrm{AIBN}(0.31 \mathrm{~g}, 1.91 \mathrm{mmol}, 0.2 \mathrm{eq})$ and tributyltinhydride $(7.7 \mathrm{~mL}, 8.36 \mathrm{~g}, 28.72 \mathrm{mmol}, 3 \mathrm{eq})$ were added at $0{ }^{\circ} \mathrm{C}$, the reaction mixture was stirred at $90{ }^{\circ} \mathrm{C}$ for 3 hours. Diastereomeric product ratio in the crude product by NMR: ciscis/cis-trans 95:5. The crude product was washed with diethyl ether to obtain the pure cis-cis isomer product. The cis-trans isomer was not isolated. White crystals (1.92 g, 71\%). mp 162.1167.3 ${ }^{\circ} \mathrm{C} .{ }^{1} \mathrm{H}$ NMR: (400 MHz, chloroform- $d$ ): 7.40 - 7.29 (5H, m, H-2', 3', 4', 5', 6'), 7.20 - 7.11 (1H, m, H-9), $6.99-6.90$ (1H, m, H-10), $6.79-6.71(1 \mathrm{H}, \mathrm{m}, \mathrm{H}-7), 6.69-6.59$ (1H, m, H-8), 4.51 $(1 \mathrm{H}, \mathrm{d}, J 5.5 \mathrm{~Hz}, \mathrm{H}-6), 4.05-3.99\left(1 \mathrm{H}, \mathrm{m}, \mathrm{H}_{\mathrm{x}}-1\right), 3.31-3.25$ (1H, m, H-4a), 3.17 (1H, dd, J 5.5 and $2.0 \mathrm{~Hz}, \mathrm{H}-5), 2.67-2.58\left(1 \mathrm{H}, \mathrm{m}, \mathrm{H}_{\mathrm{y}}-1\right), 1.94-1.70\left(5 \mathrm{H}, \mathrm{m}, \mathrm{H}_{\mathrm{x}, \mathrm{y}}-2,3, \mathrm{H}_{\mathrm{x}}-4\right), 1.45-1.33(1 \mathrm{H}$, m, $\left.\mathrm{H}_{\mathrm{y}}-4\right)$ ); ${ }^{13} \mathrm{C}$ NMR: (100 MHz, chloroform- $d$ ): 147.0 (C-10a), 140.2 (C-1'), 129.7 (C-7), 129.6 (C-2', 6'), 128.6 (C-3', 5'), 128.3 (C-9), 127.8 (C-4'), 123.2 (C-6a), 118.6 (CN), 118.4 (C-8), 113.9 (C-10), 57.7 (C-4a), 48.1 (C-1), 46.9 (C-6), 42.2 (C-5), 31.5 (C-2), 25.5 (C-3), 23.2 (C-4). Anal. calcd. for $\mathrm{C}_{20} \mathrm{H}_{20} \mathrm{~N}_{2}$ (288.39): C, 83.30\%; H, 6.99\%; N, 9.71\%. Found: C, 82.84\%; H, 6.97\%; N, 9.49\%. HRMS (ESI+) $m / z$ calcd. for $\mathrm{C}_{20} \mathrm{H}_{20} \mathrm{~N}_{2}[\mathrm{M}+\mathrm{Na}]^{+} 311.1519$, found 311.1527 .

General procedure for the reduction of mononitrile derivatives $(\operatorname{method} \mathbf{E})$. The precursor mononitrile compound ( 1 eq) was dissolved in dry $\mathrm{MeOH}$ (distilled from $\mathrm{Mg} / \mathrm{I}_{2}$ prior use) $(50 \mathrm{~mL}$ ). At $0{ }^{\circ} \mathrm{C}$ di-tert-butyl dicarbonate $\left(\mathrm{Boc}_{2} \mathrm{O}\right)(2 \mathrm{eq})$ and $\mathrm{NiCl}_{2} \times 6 \mathrm{H}_{2} \mathrm{O}(0.4 \mathrm{eq})$ were added under argon atmosphere. Subsequently $\mathrm{NaBH}_{4}$ (10 eq) was added in small portions (within 45-55 min), keeping the temperature below $5{ }^{\circ} \mathrm{C}$ (the reaction is strongly effervescent, while adding $\mathrm{NaBH}_{4}$ and the reaction mixture turns black). The mixture was allowed to warm up and was stirred for 1 hour at ambient temperature, followed by adding of $25 \%$ aq. $\mathrm{NH}_{3}(100 \mathrm{~mL})$ and the mixture was stirred for a further $1 \mathrm{~h}$. After evaporation to dryness, the residue was taken up in $300 \mathrm{~mL}$ of $\mathrm{H}_{2} \mathrm{O} / \mathrm{EtOAc}$ 2:1 and the phases were separated. The inorganic layer was extracted with EtOAc $(4 \times 50 \mathrm{~mL})$ and washed with saturated $\mathrm{NaHCO}_{3}$ solution $(2 \times 50 \mathrm{~mL})$. The organic phase was dried over $\mathrm{MgSO}_{4}$, filtered, evaporated to dryness and purified by column chromatography. 
tert-Butyl $N$-\{[cis-( \pm -1,4-dimethyl-1,2,3,4-tetrahydroquinolin-3-yl]methyl\} carbamate (13a cis) and tert-Butyl $N$-\{[trans-( \pm -1,4-dimethyl-1,2,3,4-tetrahydroquinolin-3-yl]methyl\}carbamate (13a trans). Following method $\mathbf{E}$, the title compounds were isolated. To the suspension of mononitrile compound (mixture of cis/trans) $(0.40 \mathrm{~g}, 2.16 \mathrm{mmol}, 1 \mathrm{eq})$ in dry $\mathrm{MeOH}$ $(20 \mathrm{~mL})$ di-tert-butyl dicarbonate $(0.96 \mathrm{~g}, 4.38 \mathrm{mmol}, 2 \mathrm{eq}), \mathrm{NiCl}_{2} \times 6 \mathrm{H}_{2} \mathrm{O}(0.21 \mathrm{~g}, 0.86 \mathrm{mmol}, 0.4$ eq) and $\mathrm{NaBH}_{4}(0.82 \mathrm{~g}, 21.6 \mathrm{mmol}, 10 \mathrm{eq})$ were added. The ratio of the diastereomers in the crude product by NMR: 66:34 cis/trans. After purification of the crude product by column chromatography (DCM/n-hexane $4: 1)$ white crystals were obtained $(0.50 \mathrm{~g}, 81 \%)$. Diastereomers were separated by HPLC (Chiralpak ${ }^{\circledR}$ „AD-H” amylose tris-(3,5-dimethylphenyl-carbamate), 250 $\mathrm{mm} \quad \mathrm{x} \quad 4.6 \quad \mathrm{~mm}, \quad 5 \quad \mu \mathrm{m} \quad \mathrm{d}_{\mathrm{p}}$. The mobile phase was a $n$-hexane/ethanol 50:50 and the flow rate was $0.5 \mathrm{ml} / \mathrm{min})$.

(13a cis) mp 67.0-73.5 ${ }^{\circ} \mathrm{C} .{ }^{1} \mathrm{H}$ NMR: $(500 \mathrm{MHz}$, chloroform- $d$ ): $7.08(1 \mathrm{H}, \mathrm{m}, \mathrm{H}-7), 7.00(1 \mathrm{H}, \mathrm{dm}$, $J 6.0 \mathrm{~Hz}, \mathrm{H}-5), 6.62(1 \mathrm{H}, \mathrm{m}, \mathrm{H}-6), 6.58$ (1H, dm, J 8.0 Hz, H-8), 4.60 (1H, brt, NH), 3.16 (2H, m, $\left.\mathrm{CH}_{2}-\mathrm{NH}\right), 3.13\left(2 \mathrm{H}, \mathrm{m}, \mathrm{H}_{\mathrm{x}, \mathrm{y}}-2\right), 2.94(1 \mathrm{H}, \mathrm{m}, \mathrm{H}-4), 2.90\left(3 \mathrm{H}, \mathrm{s}, \mathrm{N}-\mathrm{CH} \mathrm{H}_{3}\right), 2.18(1 \mathrm{H}, \mathrm{m}, \mathrm{H}-3), 1.46$ $\left(9 \mathrm{H}, \mathrm{s}, \mathrm{C}\left(\mathrm{CH}_{3}\right)_{3}\right), 1.13\left(3 \mathrm{H}, \mathrm{d}, J 7.5 \mathrm{~Hz}, \mathrm{CH}_{3}\right) ;{ }^{13} \mathrm{C} \mathrm{NMR}:(125 \mathrm{MHz}$, chloroform- $d): 156.0(\mathrm{C}=\mathrm{O})$,

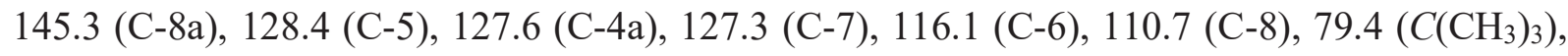
$50.0(\mathrm{C}-2), 41.1\left(\mathrm{CH}_{2}-\mathrm{NH}\right), 38.9\left(\mathrm{~N}-\mathrm{CH}_{3}\right), 37.1(\mathrm{C}-3), 33.8(\mathrm{C}-4), 28.4\left(\mathrm{C}^{\left.\left(\mathrm{CH}_{3}\right)_{3}\right),}, 17.8\left(\mathrm{CH}_{3}\right)\right.$. HRMS (ESI+) $m / z$ calcd. for $\mathrm{C}_{17} \mathrm{H}_{26} \mathrm{~N}_{2} \mathrm{O}_{2}[\mathrm{M}+\mathrm{H}]^{+} 291.2067$, found 291.2079.

(13a trans) mp 92.0-98.8 ${ }^{\circ} \mathrm{C} .{ }^{1} \mathrm{H}$ NMR: $(500 \mathrm{MHz}$, chloroform- $d)$ : $7.08(1 \mathrm{H}, \mathrm{m}, \mathrm{H}-7), 7.03(1 \mathrm{H}$, $\mathrm{dm}, J 6.5 \mathrm{~Hz}, \mathrm{H}-5), 6.65(1 \mathrm{H}, \mathrm{m}, \mathrm{H}-6), 6.60(1 \mathrm{H}, \mathrm{dm}, J 8.5 \mathrm{~Hz}, \mathrm{H}-8), 4.73(1 \mathrm{H}$, brt, NH), $3.31(1 \mathrm{H}$, dd, $J 11.5$ and $\left.3.5 \mathrm{~Hz}, \mathrm{H}_{\mathrm{x}}-2\right), 3.11-3.00\left(2 \mathrm{H}, \mathrm{m}, \mathrm{CH}_{2}-\mathrm{NH}\right), 2.98\left(1 \mathrm{H}, \mathrm{m}, \mathrm{H}_{\mathrm{y}}-2\right), 2.90(3 \mathrm{H}, \mathrm{s}, \mathrm{N}-$ $\left.\mathrm{CH}_{3}\right), 2.65(1 \mathrm{H}, \mathrm{m}, \mathrm{H}-4), 1.94(1 \mathrm{H}, \mathrm{s}, \mathrm{H}-3), 1.44\left(9 \mathrm{H}, \mathrm{s}, \mathrm{C}\left(\mathrm{CH}_{3}\right)_{3}\right), 1.27\left(3 \mathrm{H}, \mathrm{d}, J 7.0 \mathrm{~Hz}, \mathrm{CH}_{3}\right)$; ${ }^{13} \mathrm{C}$ NMR: (125 MHz, chloroform- $d$ ): $156.2(C=\mathrm{O}), 145.4(\mathrm{C}-8 \mathrm{a}), 129.6(\mathrm{C}-5), 127.1(\mathrm{C}-7), 126.0$ (C-4a), $116.6(\mathrm{C}-6), 111.1(\mathrm{C}-8), 79.2\left(C\left(\mathrm{CH}_{3}\right)_{3}\right), 49.0(\mathrm{C}-2), 42.9\left(\mathrm{CH}_{2}-\mathrm{NH}\right), 39.3\left(\mathrm{~N}_{-} \mathrm{CH}_{3}\right), 38.5$ (C-3), $33.9(\mathrm{C}-4), 28.4\left(\mathrm{C}\left(\mathrm{CH}_{3}\right)_{3}\right), 24.9\left(\mathrm{CH}_{3}\right)$. HRMS (ESI+) $\mathrm{m} / z$ calcd. for $\mathrm{C}_{17} \mathrm{H}_{26} \mathrm{~N}_{2} \mathrm{O}_{2}[\mathrm{M}+\mathrm{H}]^{+}$ 291.2067, found 291.2080.

tert-Butyl $\quad N$-\{[cis-cis-( \pm -5-methyl-1,2,3,3a,4,5-hexahydropyrrolo[1,2-a]quinolin-4yl]methyl\}carbamate (13b cis-cis) and tert-Butyl $N$-\{[cis-trans-( \pm )-5-methyl-1,2,3,3a,4,5hexahydropyrrolo[1,2-a]quinolin-4-yl]methyl\}carbamate (13b cis-trans). Following method $\mathbf{E}$, the title compound (cis-cis) was isolated. To the suspension of mononitrile compound (cis-cis) $(0.20 \mathrm{~g}, 0.96 \mathrm{mmol}, 1 \mathrm{eq})$ in dry $\mathrm{MeOH}(20 \mathrm{~mL})$, di-tert-butyl dicarbonate $(0.43 \mathrm{~g}, 1.95 \mathrm{mmol}, 2$ eq), $\mathrm{NiCl}_{2} \times 6 \mathrm{H}_{2} \mathrm{O}(0.09 \mathrm{~g}, 0.38 \mathrm{mmol}, 0.4 \mathrm{eq})$ and $\mathrm{NaBH}_{4}(0.36 \mathrm{~g}, 9.6 \mathrm{mmol}, 10 \mathrm{eq})$ were added. After purification of the crude product by column chromatography (DCM $/ n$-hexane $4: 1$ ) a beige powder was obtained $(0.05 \mathrm{~g}, 18 \%)$. mp $103.4-109.9^{\circ} \mathrm{C} .{ }^{1} \mathrm{H}$ NMR $(500 \mathrm{MHz}$, chloroform- $d$ ): 7.06 - 7.04 (2H, m, H-6, 8), 6.59 - 6.58 (1H, m, H-7), 6.33 (1H, dm, J 8.5 Hz, H-9), 4.46 (1H, brs, $\mathrm{NH}), 3.77-3.75(1 \mathrm{H}, \mathrm{m}, \mathrm{H}-3 \mathrm{a}), 3.28-3.22\left(2 \mathrm{H}, \mathrm{m}, \mathrm{H}_{\mathrm{x}, \mathrm{y}}-1\right), 3.16-3.15(1 \mathrm{H}, \mathrm{m}, \mathrm{H}-5), 3.05-3.04$ $\left(1 \mathrm{H}, \mathrm{m}, \mathrm{CH}_{2}-\mathrm{NH}\right), 2.88-2.70\left(1 \mathrm{H}, \mathrm{m}, \mathrm{CH}_{2}-\mathrm{NH}\right), 2.07-2.06\left(1 \mathrm{H}, \mathrm{m}, \mathrm{H}_{\mathrm{x}}-2\right), 2.00-1.95(2 \mathrm{H}, \mathrm{m}$, $\left.\mathrm{H}_{\mathrm{x}}-3, \mathrm{H}-4\right), 1.90-1.87\left(2 \mathrm{H}, \mathrm{m}, \mathrm{H}_{\mathrm{y}}-2,3\right), 1.45\left(3 \mathrm{H}, \mathrm{d}, J 7.5 \mathrm{~Hz}, \mathrm{CH}_{3}\right), 1.38\left(9 \mathrm{H}, \mathrm{s}, \mathrm{C}\left(\mathrm{CH}_{3}\right)_{3}\right)$; ${ }^{13} \mathrm{C}$ NMR (125 MHz, chloroform- $d$ ): $155.5(C=\mathrm{O}), 144.3$ (C-9a), 127.3 (C-8), 126.0 (C-6), 123.7 (C-5a), 115.3 (C-7), 109.1 (C-9), $78.9\left(\mathrm{C}_{\left.\left(\mathrm{CH}_{3}\right)_{3}\right),} 61.9\right.$ (C-3a), $47.0(\mathrm{C}-1), 39.9(\mathrm{C}-4), 36.1\left(\mathrm{CH}_{2}-\right.$ 
$\mathrm{NH}), 35.8(\mathrm{C}-5), 29.0(\mathrm{C}-3), 28.4\left(\mathrm{C}\left(\mathrm{CH}_{3}\right)_{3}\right), 23.7(\mathrm{C}-2), 17.1\left(\mathrm{CH}_{3}\right)$. HRMS (ESI+) $\mathrm{m} / z$ calcd. for $\mathrm{C}_{19} \mathrm{H}_{29} \mathrm{~N}_{2} \mathrm{O}_{2}[\mathrm{M}+\mathrm{H}]^{+}$317.2224, found 317.2236.

Following method E, the title compound (cis-trans) was isolated. To the suspension of mononitrile compound (cis-trans) $(0.30 \mathrm{~g}, 1.41 \mathrm{mmol}, 1 \mathrm{eq})$ in dry $\mathrm{MeOH}(20 \mathrm{~mL})$, di-tert-butyl dicarbonate $(0.63 \mathrm{~g}, 2.86 \mathrm{mmol}, 2 \mathrm{eq}), \mathrm{NiCl}_{2} \times 6 \mathrm{H}_{2} \mathrm{O}(0.13 \mathrm{~g}, 0.56 \mathrm{mmol}, 0.4 \mathrm{eq})$ and $\mathrm{NaBH}_{4}(0.53 \mathrm{~g}$, $14.1 \mathrm{mmol}, 10 \mathrm{eq})$ were added. After the work up, pale yellow crystals were obtained $(0.41 \mathrm{~g}$, 91\%). mp 80.7 - 82.9 ${ }^{\circ} \mathrm{C} .{ }^{1} \mathrm{H}$ NMR (500 MHz, chloroform- $\left.d\right): 7.19$ (1H, dm, J 7.5 Hz, H-6), 7.08 $(1 \mathrm{H}, \mathrm{m}, \mathrm{H}-8), 6.65$ (1H, m, H-7), 6.44 (1H, dm, J 8.0 Hz, H-9), 4.57 (1H, brt, NH), 3.51 - 3.39 $\left(2 \mathrm{H}, \mathrm{m}, \mathrm{CH}_{2}-\mathrm{NH}\right), 3.34-3.33\left(1 \mathrm{H}, \mathrm{m}, \mathrm{H}_{\mathrm{x}}-1\right), 3.19-3.18\left(1 \mathrm{H}, \mathrm{m}, \mathrm{H}_{\mathrm{y}}-1\right), 3.07-3.06(1 \mathrm{H}, \mathrm{m}, \mathrm{H}-3 \mathrm{a})$, $2.76-2.73(1 \mathrm{H}, \mathrm{m}, \mathrm{H}-5), 2.32-2.30\left(1 \mathrm{H}, \mathrm{m}, \mathrm{H}_{\mathrm{x}}-3\right), 2.09-2.07\left(1 \mathrm{H}, \mathrm{m}, \mathrm{H}_{\mathrm{x}}-2\right), 1.91-1.89(1 \mathrm{H}$, $\left.\mathrm{m}, \mathrm{H}_{\mathrm{y}}-2\right), 1.59-1.56\left(1 \mathrm{H}, \mathrm{m}, \mathrm{H}_{\mathrm{y}}-3\right), 1.44\left(9 \mathrm{H}, \mathrm{m}, \mathrm{C}\left(\mathrm{CH}_{3}\right)_{3}\right), 1.37\left(\mathrm{H}, \mathrm{d}, J 7.0 \mathrm{~Hz}, \mathrm{CH}_{3}\right), 1.35-$ $1.33(1 \mathrm{H}, \mathrm{m}, \mathrm{H}-4) ;{ }^{13} \mathrm{C}$ NMR (125 MHz, chloroform- $\left.d\right)$ : $156.2(C=\mathrm{O}), 144.7$ (C-9a), 127.0 (C-6), 127.0 (C-8), 126.8 (C-5a), 115.9 (C-7), 110.6 (C-9), $79.3\left(C\left(\mathrm{CH}_{3}\right)_{3}\right), 59.9$ (C-3a), 47.3 (C-1), 45.7 (C-4), $40.6\left(\mathrm{CH}_{2}-\mathrm{NH}\right), 33.0(\mathrm{C}-5), 32.1(\mathrm{C}-3), 28.4\left(\mathrm{C}\left(\mathrm{CH}_{3}\right)_{3}\right), 23.1(\mathrm{C}-2), 18.8\left(\mathrm{CH}_{3}\right)$. HRMS (ESI+) $m / z$ calcd. for $\mathrm{C}_{19} \mathrm{H}_{29} \mathrm{~N}_{2} \mathrm{O}_{2}[\mathrm{M}+\mathrm{H}]^{+} 317.2224$, found 317.2237 .

tert-Butyl $\quad N$-\{[cis-cis- $( \pm)-6$-methyl-1H-2,3,4,4a,5,6-hexahydropyrido[1,2-a]quinolin-5yl]methyl \} carbamate (13c cis-cis). Following method $\mathbf{E}$, the title compound was isolated. To the suspension of mononitrile compound (cis-cis) (1.01 g, $3.47 \mathrm{mmol}, 1 \mathrm{eq})$ in dry $\mathrm{MeOH}(50 \mathrm{~mL})$, di-tert-butyl dicarbonate $(1.52 \mathrm{~g}, 6.94 \mathrm{mmol}, 2 \mathrm{eq}), \mathrm{NiCl}_{2} \times 6 \mathrm{H}_{2} \mathrm{O}(0.49 \mathrm{~g}, 2.08 \mathrm{mmol}, 0.6 \mathrm{eq})$ and $\mathrm{NaBH}_{4}(1.18 \mathrm{~g}, 31.21 \mathrm{mmol}, 9$ eq) were added. The crude product was purified by column chromatography (DCM/MeOH 100:1). White powder (0.36 g, 27\%). mp 111-113 ${ }^{\circ} \mathrm{C} .{ }^{1} \mathrm{H}$ NMR: (500 MHz, dimethyl sulfoxide- $\left.d_{6}\right): 7.03(1 \mathrm{H}, \mathrm{m}, \mathrm{H}-9), 7.03(1 \mathrm{H}, \mathrm{dm}, J 7.0 \mathrm{~Hz}, \mathrm{H}-7), 6.85$ (1H, brd, H-10), 6.67 (1H, m, H-8), 6.64 (1H, brs, NH), 3.98 (1H, dm, J 12.5 Hz, H-1), $3.16(1 \mathrm{H}, \mathrm{m}, \mathrm{H}-4 \mathrm{a})$, $3.10\left(1 \mathrm{H}, \mathrm{m}, \mathrm{CH}_{2}-\mathrm{NH}\right), 2.99(1 \mathrm{H}, \mathrm{m}, \mathrm{H}-6), 2.90\left(1 \mathrm{H}, \mathrm{m}, \mathrm{CH}_{2}-\mathrm{NH}\right), 2.72\left(1 \mathrm{H}, \mathrm{m}, \mathrm{H}_{\mathrm{x}}-1\right), 2.09(1 \mathrm{H}$, m, H-5), 1.87 - 1.29 (6H, m, $\left.\mathrm{H}_{\mathrm{x}, \mathrm{y}}-2,3,4\right), 1.38\left(9 \mathrm{H}, \mathrm{s}, \mathrm{C}\left(\mathrm{CH}_{3}\right)_{3}\right), 1.24$ (3H, d, J $\left.7.5 \mathrm{~Hz}, \mathrm{CH}_{3}\right)$; ${ }^{13} \mathrm{C}$ NMR: (125 MHz, dimethyl sulfoxide- $\left.d_{6}\right): 156.0(C=\mathrm{O}), 144.1$ (C-10a), 128.9 (C-6a), 127.4 (C-7), 126.7 (C-9), 117.7 (C-8), $\left.113.0(\mathrm{C}-10), 77.2\left(\mathrm{C}_{(\mathrm{CH}}\right)_{3}\right), 60.1(\mathrm{C}-4 \mathrm{a}), 48.5(\mathrm{C}-1), 41.0$ (C5), $37.8\left(\mathrm{CH}_{2}-\mathrm{NH}\right), 34.0(\mathrm{C}-6), 28.1\left(\mathrm{C}\left(\mathrm{CH}_{3}\right)_{3}\right), 28.1,25.1,24.9(\mathrm{C}-2,3,4), 17.0\left(\mathrm{CH}_{3}\right)$. HRMS (ESI+) $m / z$ calcd. for $\mathrm{C}_{20} \mathrm{H}_{31} \mathrm{~N}_{2} \mathrm{O}_{2}[\mathrm{M}+\mathrm{H}]^{+} 331.2380$, found 331.2391 .

tert-Butyl $N$-\{[cis-( \pm -1-methyl-4-phenyl-1,2,3,4-tetrahydroquinolin-3-yl]methyl\} carbamate (14a cis). Following method $\mathbf{E}$, the title compound (cis) was isolated. To the suspension of the mononitrile compound (cis) $(0.48 \mathrm{~g}, 1.95 \mathrm{mmol}, 1 \mathrm{eq})$ in dry $\mathrm{MeOH}(25 \mathrm{~mL})$, di-tert-butyl dicarbonate $(0.86 \mathrm{~g}, 3.96 \mathrm{mmol}, 2 \mathrm{eq}), \mathrm{NiCl}_{2} \times 6 \mathrm{H}_{2} \mathrm{O}(0.19 \mathrm{~g}, 0.78 \mathrm{mmol}, 0.4 \mathrm{eq})$ and $\mathrm{NaBH}_{4}$ ( $0.74 \mathrm{~g}, 19.45 \mathrm{mmol}, 10 \mathrm{eq})$ were added. After washing the crude product with diethyl ether, white crystals were obtained $(0.67 \mathrm{~g}, 98 \%)$. mp $162.3-163.0{ }^{\circ} \mathrm{C} .{ }^{1} \mathrm{H}$ NMR: $(600 \mathrm{MHz}$, chloroform- $d$ ): $7.28-7.09$ (4H, m, H-7, 3', 4', 5'), $7.05-6.98$ (2H, m, H-2', 6'), 6.90 - 6.85 (1H, dm, J 7.6 Hz, H-5), 6-72 - 6.67 (1H, dm, J8.5 Hz, H-8), $6.59-6.53(1 \mathrm{H}, \mathrm{m}, \mathrm{H}-6), 4.47$ (1H, brs, NH), $4.14(1 \mathrm{H}$, d, J 4.9 Hz, H-4), $3.19-3.09\left(2 \mathrm{H}, \mathrm{m}, \mathrm{CH}_{2}-\mathrm{NH}\right), 3.08-3.02\left(1 \mathrm{H}, \mathrm{m}, \mathrm{H}_{\mathrm{x}}-2\right), 3.00\left(3 \mathrm{H}, \mathrm{s}, \mathrm{CH}_{3}\right)$, $2.79-2.68\left(1 \mathrm{H}, \mathrm{m}, \mathrm{H}_{\mathrm{y}}-2\right), 2.48-2.37(1 \mathrm{H}, \mathrm{m}, \mathrm{H}-3), 1.42\left(9 \mathrm{H}, \mathrm{s}, \mathrm{C}\left(\mathrm{CH}_{3}\right)_{3}\right) .{ }^{13} \mathrm{C} \mathrm{NMR}:(150 \mathrm{MHz}$, chloroform- $d$ ): 155.9 (C=O), 145.9 (C-8a), 142.2 (C-1'), 130.2 (C-5), 129.5 (C-2', 6'), 128.1 (C- 


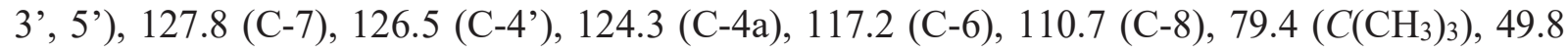

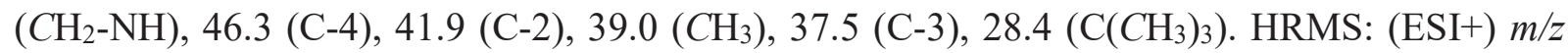
calcd. for $\mathrm{C}_{22} \mathrm{H}_{29} \mathrm{~N}_{2} \mathrm{O}_{2}[\mathrm{M}+\mathrm{H}]^{+}$353.2224; found. 353.2221.

tert-Butyl $\quad N$-\{[cis-trans-( \pm )-5-phenyl-1,2,3,3a,4,5-hexahydropyrrolo[1,2-a]quinolin-4-yl]methyl\} carbamate (14b cis-trans).Following method $\mathbf{E}$, the title compound was isolated. To the suspension of the mononitrile compound (cis-trans) $(0.30 \mathrm{~g}, 1.09 \mathrm{mmol}, 1 \mathrm{eq})$ in dry $\mathrm{MeOH}$ (20 mL), di-tert-butyl dicarbonate $(0.48 \mathrm{~g}, 2.21 \mathrm{mmol}, 2 \mathrm{eq}), \mathrm{NiCl}_{2} \times 6 \mathrm{H}_{2} \mathrm{O}(0.10 \mathrm{~g}, 0.44 \mathrm{mmol}, 0.4$ eq) and $\mathrm{NaBH}_{4}(0.41 \mathrm{~g}, 10.93 \mathrm{mmol}, 10 \mathrm{eq})$ were added. After purification of the crude product by column chromatography (DCM) white crystals were obtained $(0.11 \mathrm{~g}, 27 \%)$. mp 187.5 $189.0{ }^{\circ} \mathrm{C}$ (dec.). ${ }^{1} \mathrm{H}$ NMR: (400 MHz, chloroform- $d$ ): 7.39 - 7.14 (5H, m, H-2', 3', 4', 5', 6'), 7.07 - 7.03 (1H, m, H-8), 6.47 (1H, m, H-6), 6.45 (1H, dm, J 8.4 Hz, H-9), 6.44 (1H, m, H-7), 4.19 (1H, brt, NH), $3.84(1 \mathrm{H}, \mathrm{d}, J 11.4 \mathrm{~Hz}, \mathrm{H}-5), 3.38-3.36\left(1 \mathrm{H}, \mathrm{m}, \mathrm{H}_{\mathrm{x}}-1\right), 3.35-3.32\left(1 \mathrm{H}, \mathrm{m}, \mathrm{H}_{\mathrm{y}}-1\right)$, $3.33(1 \mathrm{H}, \mathrm{m}, \mathrm{H}-3 \mathrm{a}), 3.21\left(1 \mathrm{H}, \mathrm{m}, \mathrm{CH}_{2}-\mathrm{NH}\right), 3.11\left(1 \mathrm{H}, \mathrm{m}, \mathrm{CH}_{2}-\mathrm{NH}\right), 2.43-2.42\left(1 \mathrm{H}, \mathrm{m}, \mathrm{H}_{\mathrm{x}}-3\right)$, $2.13-2.10\left(1 \mathrm{H}, \mathrm{m}, \mathrm{H}_{\mathrm{x}}-2\right), 1.95\left(1 \mathrm{H}, \mathrm{m}, \mathrm{H}_{\mathrm{y}}-2\right), 1.85(1 \mathrm{H}, \mathrm{m}, \mathrm{H}-4), 1.64\left(1 \mathrm{H}, \mathrm{m}, \mathrm{H}_{\mathrm{y}}-3\right), 1.40(9 \mathrm{H}$, s, $\left.\mathrm{C}\left(\mathrm{CH}_{3}\right)_{3}\right)$; ${ }^{13} \mathrm{C}$ NMR: (100 MHz, chloroform- $d$ ): $155.9(\mathrm{C}=\mathrm{O}), 144.5$ (C-9a), $144.0\left(\mathrm{C}-1^{\prime}\right), 129.5$ (C-6), 129.4 (C-2', 6’), 128.8 (C-4'), 127.4 (C-8), 126.8 (C-3', 5'), 125.5 (C-5a), 115.3 (C-7),

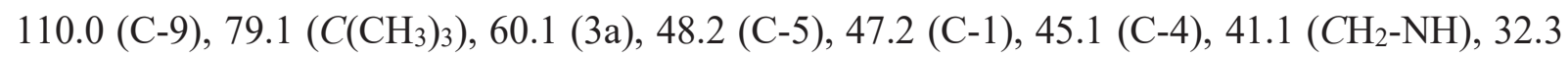
(C-3), $28.4\left(\mathrm{C}\left(\mathrm{CH}_{3}\right)_{3}\right), 23.4$ (C-2). HRMS: (ESI+) $\mathrm{m} / z$ calcd. for $\mathrm{C}_{24} \mathrm{H}_{31} \mathrm{~N}_{2} \mathrm{O}_{2}[\mathrm{M}+\mathrm{H}]^{+}$379.2380; found: 379.2374 .

tert-Butyl $\quad N$-(\{cis-cis-( \pm )-6-phenyl-1,2,3,4,4a,5,6-hexahydropyrido[1,2-a]quinolin-5-yl\}methyl)carbamate (14c cis-cis). Following method $\mathbf{E}$, the title compound was isolated. To the suspension of the mononitrile compound (cis-cis) (1.01 g, $3.47 \mathrm{mmol}, 1 \mathrm{eq})$ in dry $\mathrm{MeOH}(50 \mathrm{~mL})$, di-tert-butyl dicarbonate (1.52 g, $6.94 \mathrm{mmol}, 2 \mathrm{eq}), \mathrm{NiCl}_{2} \times 6 \mathrm{H}_{2} \mathrm{O}(0.49 \mathrm{~g}, 2.00 \mathrm{mmol}, 0.6 \mathrm{eq})$ and $\mathrm{NaBH}_{4}(1.18 \mathrm{~g}, 31.21 \mathrm{mmol}, 9$ eq) were added. After the column chromatography (DCM/MeOH 100:1) the product was washed with $n$-hexane. White crystals $(0.36 \mathrm{~g}, 27 \%) \mathrm{mp} 111.0-113.0{ }^{\circ} \mathrm{C}$. ${ }^{1} \mathrm{H}$ NMR: (400 MHz, chloroform- $d$ ): 7.36 - 7.15 (5H, m, H-2', 3', 4', 5', 6'), 7.16 - 7.13 (1H, m, H-9), 6.99 (1H, dm, J 7.5 Hz, H-7), 6.89 (1H, dm, J 8.2 Hz, H-10), 6.67 (1H, m, H-8), 4.51 (1H, d, J 5.4 Hz, H-6), $3.93\left(1 \mathrm{H}, \mathrm{m}, \mathrm{H}_{\mathrm{x}}-1\right), 3.80(1 \mathrm{H}, \mathrm{brt}, \mathrm{NH}), 3.49\left(1 \mathrm{H}, \mathrm{m}, \mathrm{CH}_{2}-\mathrm{NH}\right), 3.20(1 \mathrm{H}, \mathrm{m}, \mathrm{H}-$ 4a), 3.03 (1H, m, CH $\left.H_{2}-\mathrm{NH}\right), 2.57$ (1H, m, $\left.\mathrm{H}_{\mathrm{y}}-1\right), 2.09$ (1H, m, H-5), $1.90-1.28$ (6H, m, $\mathrm{H}_{\mathrm{x}, \mathrm{y}}-2,3$, 4), 1.34 (9H, s, $\left.\mathrm{C}\left(\mathrm{CH}_{3}\right)_{3}\right)$; ${ }^{13} \mathrm{C}$ NMR: (100 MHz, chloroform- $d$ ): $155.5(\mathrm{C}=\mathrm{O}), 148.4(\mathrm{C}-10 \mathrm{a}), 142.6$ (C-1'), 130.2 (C-7), 129.2 (C-2', 6'), 128.8 (C-3', 5'), 127.6 (C-9), 126.5 (C-4'), 125.7 (C-6a), 117.7 (C-8), $113.4(\mathrm{C}-10), 78.6\left(C\left(\mathrm{CH}_{3}\right)_{3}\right), 60.1$ (C-4a), $48.5(\mathrm{C}-1), 48.5$ (C-6), 45.4 (C-5), 38.3 $\left(\mathrm{CH}_{2}-\mathrm{NH}\right), 28.0(\mathrm{C}-2), 27.3\left(\mathrm{C}\left(\mathrm{CH}_{3}\right)_{3}\right), 25.8(\mathrm{C}-3), 23.9(\mathrm{C}-4)$. Anal. calcd. for $\mathrm{C}_{25} \mathrm{H}_{32} \mathrm{~N}_{2} \mathrm{O}_{2}$ (392.53): C, 76.49\%; H, 8.22\%; N, 7.14\%. Found: C, 76.35\%; H, 8.45\%; N, 7.09\%. HRMS: (ESI+) $m / z$ calcd. for $\mathrm{C}_{25} \mathrm{H}_{33} \mathrm{~N}_{2} \mathrm{O}_{2}[\mathrm{M}+\mathrm{H}]^{+}$393.2537; found: 393.2532 .

General procedure for the preparation of $\mathrm{HCl}$ salts (method F). The Boc-protected amine precursor (1 eq) was dissolved in dry EtOAc (distilled from Na, dried over $4 \AA$ molecular sieves). At $0{ }^{\circ} \mathrm{C}, 4 \mathrm{M} \mathrm{HCl} / \mathrm{EtOAc}$ was added dropwise, until $\mathrm{pH}=1-2$. The reaction mixture was stirred 
overnight at room temperature. The precipitated crystals were filtered off and washed with diethyl ether to afford the product.

(cis-( \pm )-1,4-Dimethyl-1,2,3,4-tetrahydroquinolin-3-yl)methanamine

dihydrochloride

(11a cis). Following method F, the title compound was isolated. Hygroscopic off-white powder (0.08 g, 71\%). mp $205.3-207.9^{\circ} \mathrm{C}$ (red foam). ${ }^{1} \mathrm{H}$ NMR (500 MHz, dimethyl sulfoxide- $d_{6}$ ): 8.26 ( $3 \mathrm{H}$, brs, $\left.\mathrm{NH}_{3}{ }^{+}\right), 7.00-7.03(1 \mathrm{H}, \mathrm{m}, \mathrm{H}-7), 6.97(1 \mathrm{H}, \mathrm{dm}, J 7 \mathrm{~Hz}, \mathrm{H}-5), 6.67$ (1H, brd, H-8), 6.63 (1H, brm, H-6), 3.32 (1H, dd, $J 11.5$ and $\left.3.5 \mathrm{~Hz}, \mathrm{H}_{\mathrm{x}}-2\right), 3.10\left(1 \mathrm{H}, \mathrm{t}, J 11 \mathrm{~Hz}, \mathrm{H}_{\mathrm{y}}-2\right), 2.99-2.97$ $(1 \mathrm{H}, \mathrm{m}, \mathrm{H}-4), 2.88\left(3 \mathrm{H}, \mathrm{s} . \mathrm{N}-\mathrm{CH}_{3}\right), 2.87-2.86\left(1 \mathrm{H}, \mathrm{m}, \mathrm{CH}_{2}\right), 2.74-2.72\left(1 \mathrm{H}, \mathrm{m}, \mathrm{CH}_{2}\right), 2.34-$ 2.29 (1H, m, H-3), 1.05 (3H, d, $\left.J 7 \mathrm{~Hz}, \mathrm{CH}_{3}\right) .{ }^{13} \mathrm{C}$ NMR (125 MHz, dimethyl sulfoxide- $\left.d_{6}\right): 144.3$ (C-8a), 128.8 (C-5), 128.2 (C-4a), 127.7 (C-7), 117.6 (C-6), 112.2 (C-8), 49.0 (C-2), $39.6\left(\mathrm{~N}_{-} \mathrm{CH}_{3}\right)$, $39.2\left(\mathrm{CH}_{2}\right), 34.5(\mathrm{C}-3), 33.1(\mathrm{C}-4), 18.2\left(\mathrm{CH}_{3}\right)$. Anal. calcd. for $\mathrm{C}_{12} \mathrm{H}_{18} \mathrm{~N}_{2} \mathrm{x} 2 \mathrm{HCl}$ (263.21): C, $54.76 \%$; H, 7.66\%; N, 10.64\%. Found: C, 54.57\%; H, 7.58\%; N, 10.51\%. HRMS: (ESI + ) $\mathrm{m} / \mathrm{z}$ calcd. for $\mathrm{C}_{12} \mathrm{H}_{19} \mathrm{~N}_{2}[\mathrm{M}+\mathrm{H}]^{+} 191.1548$; found: 191.1544 .

[cis-trans-( \pm )-5-Methyl-1,2,3,3a,4,5-hexahydropyrrolo[1,2-a]quinolin-4-yl]methanamine

dihydrochloride (11b cis-trans). Following method $\mathbf{F}$, the title compound was isolated. White powder $(0.26 \mathrm{~g}, 95 \%)$. mp $145.8-148.4{ }^{\circ} \mathrm{C} .{ }^{1} \mathrm{H}$ NMR $\left(500 \mathrm{MHz}\right.$, dimethyl sulfoxide- $\left.d_{6}\right): 8.25$ $\left(3 \mathrm{H}\right.$, brs, $\left.\mathrm{NH}_{3}{ }^{+}\right), 7.15(1 \mathrm{H}, \mathrm{dm}, J 7.5 \mathrm{~Hz}, \mathrm{H}-6), 7.05-7.02(1 \mathrm{H}, \mathrm{m}, \mathrm{H}-8), 6.67-6.64(1 \mathrm{H}, \mathrm{m}, \mathrm{H}-$ 7), $6.49(1 \mathrm{H}, \mathrm{dm}, J 8.0 \mathrm{~Hz}, \mathrm{H}-9), 3.30-3.28\left(1 \mathrm{H}, \mathrm{m}, \mathrm{H}_{\mathrm{x}}-1\right), 3.18-3.15\left(2 \mathrm{H}, \mathrm{m}, \mathrm{H}_{\mathrm{y}}-1, \mathrm{H}-3 \mathrm{a}\right), 3.09$ - $3.08\left(1 \mathrm{H}, \mathrm{m}, \mathrm{CH}_{2}\right), 3.01-2.90\left(1 \mathrm{H}, \mathrm{m}, \mathrm{CH}_{2}\right), 2.89-2.87(1 \mathrm{H}, \mathrm{m}, \mathrm{H}-5), 2.35-2.33\left(1 \mathrm{H}, \mathrm{m}, \mathrm{H}_{\mathrm{x}}-\right.$ 3), $2.04-2.02\left(1 \mathrm{H}, \mathrm{m}, \mathrm{H}_{\mathrm{x}}-2\right), 1.86-1.84\left(1 \mathrm{H}, \mathrm{m}, \mathrm{H}_{\mathrm{y}}-2\right), 1.58-1.52\left(2 \mathrm{H}, \mathrm{m}, \mathrm{H}_{\mathrm{y}}-3, \mathrm{H}-4\right), 1.27$ (3H, d, J 7.0 Hz, CH3); ${ }^{13} \mathrm{C}$ NMR (125 MHz, dimethyl sulfoxide- $\left.d_{6}\right): 143.9$ (C-9a), 127.4 (C-6), 127.3 (C-8), 127.3 (C-5a), 117.4 (C-7), 112.1 (C-9), 59.7 (C-3a), 48.1 (C-1), 43.2 (C-4), $39.4\left(\mathrm{CH}_{2}\right), 32.6$ (C-5), 31.1 (C-3), 22.8 (C-2), $19.4\left(\mathrm{CH}_{3}\right)$. Anal. calcd. for $\mathrm{C}_{14} \mathrm{H}_{20} \mathrm{~N}_{2}$ x $2 \mathrm{HCl}$ (289.24): C, 58.13\%; H, 7.67\%; N, 9.69\%. Found: C, 57.97\%; H, 7.79\%; N, 9.26\%. HRMS: calcd. for $\mathrm{C}_{14} \mathrm{H}_{21} \mathrm{~N}_{2}[\mathrm{M}+\mathrm{H}]^{+}$ 217.1699; found. 217.1710.

[cis-trans-( \pm )-6-Methyl-1H-2,3,4,4a,5,6-hexahydropyrido[1,2-a]quinolin-5-yl]methanamine trihydrochloride (11c cis-trans). Following method $\mathbf{F}$, the title compound was isolated. White powder $(0.26 \mathrm{~g}, 29 \%) \mathrm{mp} 162-166{ }^{\circ} \mathrm{C} .{ }^{1} \mathrm{H}$ NMR: (500 MHz, dimethyl sulfoxide- $\left.d_{6}\right): 8.19(3 \mathrm{H}$, brs, $\left.\mathrm{NH}_{3}^{+}\right), 7.12-7.09(2 \mathrm{H}, \mathrm{m}, \mathrm{H}-7,9), 6.85(1 \mathrm{H}$, brd, H-10), $6.77(1 \mathrm{H}$, brt, $\mathrm{H}-8), 3.73(1 \mathrm{H}, \mathrm{dm}$, $\left.J 13.0 \mathrm{~Hz}, \mathrm{H}_{\mathrm{x}}-1\right), 2.87-2.85(1 \mathrm{H}, \mathrm{m}, \mathrm{H}-4 \mathrm{a}), 2.85-2.84(1 \mathrm{H}, \mathrm{m}, \mathrm{H}-6), 2.78-2.75\left(1 \mathrm{H}, \mathrm{m}, \mathrm{H}_{\mathrm{y}}-1\right)$, $2.67-2.62\left(2 \mathrm{H}, \mathrm{m}, \mathrm{CH}_{2}\right), 2.03-2.01(1 \mathrm{H}, \mathrm{m}, \mathrm{H}-5), 1.85-1.40\left(6 \mathrm{H}, \mathrm{m}, \mathrm{H}_{\mathrm{x}, \mathrm{y}}-2,3,4\right), 1.31(3 \mathrm{H}$, d, $\left.J 7.5 \mathrm{~Hz}, \mathrm{CH}_{3}\right) ;{ }^{13} \mathrm{C}$ NMR: (125 MHz, dimethyl sulfoxide- $\left.d_{6}\right): 144.0$ (C-10a), 129.5 (C-6a), 127.9 (C-7), 127.0 (C-9), 118.8 (C-8), 112.9 (C-10), 59.0 (C-4a), 47.7 (C-1), 44.1 (C-5), 42.2 $\left(\mathrm{CH}_{2}\right), 33.0(\mathrm{C}-6), 32.0,23.7,23.7(\mathrm{C}-2,3,4), 20.4\left(\mathrm{CH}_{3}\right)$. Anal. calcd. for $\mathrm{C}_{15} \mathrm{H}_{22} \mathrm{~N}_{2} \times 3 \mathrm{HCl}$ (339.73): C, 53.03\%; H, 7.42\%; N, 8.25\%. Found: C, 52.93\%; H, 7.53\%; N, 7.99\%. HRMS: (ESI+) $m / z$ calcd. for $\mathrm{C}_{15} \mathrm{H}_{23} \mathrm{~N}_{2}[\mathrm{M}+\mathrm{H}]^{+} 231.1856$; found: 231.1851 .

[cis-( \pm -1-Methyl-4-phenyl-1,2,3,4-tetrahydroquinolin-3-yl]methanamine dihydrochloride (12a cis). Following method F, the title compound was isolated. Cream powder $(0.37 \mathrm{~g}, 65 \%)$. mp 177.3 - $181.3{ }^{\circ} \mathrm{C} .{ }^{1} \mathrm{H}$ NMR: (400 MHz, dimethyl sulfoxide- $d_{6}$ ): 8.20 (3H, brs, $\mathrm{H}-\mathrm{NH}_{3}{ }^{+}$), 7.28 
- 7.27 (2H, m, H-3', 5'), 7.22 - 7.21 (1H, m, H-4'), 7.03 - 7.11 (3H, ovl. m, H-2', 6', 7), 6.76 $6.75(2 \mathrm{H}, \mathrm{m}, \mathrm{H}-5,8), 6.51(1 \mathrm{H}, \mathrm{t}, J 7.2 \mathrm{~Hz}, \mathrm{H}-6), 4.27(1 \mathrm{H}, \mathrm{d}, J 4.4 \mathrm{~Hz}, \mathrm{H}-4), 3.37$ (1H, dd, $J 11.7$ and $\left.2.8 \mathrm{~Hz}, \mathrm{H}_{\mathrm{x}}-2\right), 2.99\left(1 \mathrm{H}, \mathrm{t}, 11.7 \mathrm{~Hz}, \mathrm{H}_{\mathrm{y}}-2\right), 2.97\left(3 \mathrm{H}, \mathrm{s}, \mathrm{CH}_{3}\right), 2.86-2.84\left(1 \mathrm{H}, \mathrm{m}, \mathrm{CH}_{2}\right), 2.48$ - $2.37(1 \mathrm{H}, \mathrm{m}, \mathrm{H}-3), 2.09-2.07\left(1 \mathrm{H}, \mathrm{m}, \mathrm{CH}_{2}\right) .{ }^{13} \mathrm{C}$ NMR: (100 MHz, dimethyl sulfoxide- $\left.d_{6}\right)$ : 145.4 (C-8a), 142.2 (C-1'), 129.7 (C-5), 129.6 (C-2', 6'), 128.2 (C-3', 5'), 128.0 (C-7), 126.7 (C4'), 123.9 (C-4a), 116.3 (C-6), 111.2 (C-8), 48.6 (C-2), $45.0(\mathrm{C}-4), 39.8\left(\mathrm{CH}_{2}\right), 38.9\left(\mathrm{CH}_{3}\right), 34.6$ (C-3). Anal. calcd. for $\mathrm{C}_{17} \mathrm{H}_{20} \mathrm{Cl}_{2} \mathrm{~N}_{2} \times 2 \mathrm{HCl}$ (325.28): C, 60.85\%; H, 7.45\%; N, 7.24\%. Found: C, 60.91\%; H, 7.27\%; N, 7.24\%. HRMS: (ESI+) $m / z$ calcd. for $\mathrm{C}_{17} \mathrm{H}_{21} \mathrm{~N}_{2}[\mathrm{M}+\mathrm{H}]^{+} 253.1699$; found. 253.1691 .

\section{[cis-trans-( \pm -5-Phenyl-1,2,3,3a,4,5-pyrrolo[1,2-a]quinolin-4-yl]methanamine}

dihydrochloride (12b cis-trans). Following method $\mathbf{F}$, the title compound was isolated. Brown shiny crystals $(0.05 \mathrm{~g}, 54 \%)$. mp $183.7-185.4{ }^{\circ} \mathrm{C}$ (foaming). ${ }^{1} \mathrm{H}$ NMR $(600 \mathrm{MHz}$, dimethyl sulfoxide - $\left.d_{6}\right): 8.16\left(3 \mathrm{H}\right.$, brt, $\left.\mathrm{NH}_{3}{ }^{+}\right), 7.43-7.19\left(5 \mathrm{H}, \mathrm{m}, \mathrm{H}-2^{\prime}, 3^{\prime}, 4^{\prime}, 5^{\prime}, 6^{\prime}\right), 7.02$ - $6.98(1 \mathrm{H}, \mathrm{m}$, H-8), 6.44 (1H, dm, J 8.0 Hz, H-9), $6.39-6.36$ (1H, m, H-7), 6.26 (1H, dm, J 7.5 Hz, H-6) 4.17 $(1 \mathrm{H}, \mathrm{d}, J 12.0 \mathrm{~Hz}, \mathrm{H}-5), 3.36-3.33(1 \mathrm{H}, \mathrm{m}, \mathrm{H}-3 \mathrm{a}), 3.31-3.29\left(1 \mathrm{H}, \mathrm{m}, \mathrm{H}_{\mathrm{x}}-1\right), 3.25$ - $3.24(1 \mathrm{H}, \mathrm{m}$, $\left.\mathrm{H}_{\mathrm{y}}-1\right), 2.83-2.80\left(1 \mathrm{H}, \mathrm{m}, \mathrm{CH}_{2}\right), 2.57-2.55\left(1 \mathrm{H}, \mathrm{m}, \mathrm{CH}_{2}\right), 2.50-2.48\left(1 \mathrm{H}, \mathrm{m}, \mathrm{H}_{\mathrm{x}}-3\right), 2.08-2.06$ $\left(1 \mathrm{H}, \mathrm{m}, \mathrm{H}_{\mathrm{x}}-2\right), 1.90-1.88\left(1 \mathrm{H}, \mathrm{m}, \mathrm{H}_{\mathrm{y}}-2\right), 1.56-1.54\left(1 \mathrm{H}, \mathrm{m}, \mathrm{H}_{\mathrm{y}}-3\right) ;{ }^{13} \mathrm{C}$ NMR $(150 \mathrm{MHz}$, dimethyl sulfoxide- $d_{6}$ ): 144.0 (C-9a), 143.4 (C-1'), 129.3 (C-2', 6'), 129.1 (C-6), 128.8 (C-4'), 127.2 (C-8), 126.9 (C-3', 5'), 124.9 (C-5a), 115.3 (C-7), 110.4 (C-9), 58.8 (C-3a), 46.7 (C-1), 45.2 (C-5), 42.0 (C-4), $38.8\left(\mathrm{CH}_{2}\right), 30.9$ (C-3), 22.8 (C-2). Anal. calcd. for $\mathrm{C}_{19} \mathrm{H}_{22} \mathrm{~N}_{2}$ x 2HCl (351.32): C, 64.96\%; H, 6.89\%; N, 7.97\%. Found: C, 65.15\%; H, 6.68\%; N, 8.20\%. HRMS: (ESI+) $m / z$ calcd. for $\mathrm{C}_{19} \mathrm{H}_{23} \mathrm{~N}_{2}[\mathrm{M}+\mathrm{H}]^{+}$279.1864; found. 279.1864.

\section{[cis-cis-( \pm )-6-Phenyl-1H-2,3,4,4a,5,6-hexahydropyrido[1,2-a]quinolin-5-yl]methanamine}

dihydrochloride (12c cis-cis). Following method F, the title compound was isolated. White powder $(0.12 \mathrm{~g}, 76 \%)$. mp $215.8-221.0{ }^{\circ} \mathrm{C}$ (foaming). ${ }^{1} \mathrm{H}$ NMR: (600 MHz, dimethyl sulfoxide$\left.d_{6}\right): 8.16\left(3 \mathrm{H}, \mathrm{s}, \mathrm{NH}_{3}{ }^{+}\right), 7.27$ (2H, t, J 7.2 Hz, H-3', 5'), 7.17 - 7.23 (3H, ovl. m, H-2', 4', 6'), 7.11 $(1 \mathrm{H}, \mathrm{t}, J 7.7 \mathrm{~Hz}, \mathrm{H}-9), 6.90(1 \mathrm{H}, \mathrm{d}, J 8.2 \mathrm{~Hz}, \mathrm{H}-10), 6.80(1 \mathrm{H}, \mathrm{d}, J 7.2 \mathrm{~Hz}, \mathrm{H}-7), 6.58$ (1H, d, J 7.7 Hz, H-8), $4.38(1 \mathrm{H}, \mathrm{d}, J 4.7 \mathrm{~Hz}, \mathrm{H}-6), 4.01\left(1 \mathrm{H}, \mathrm{d}, J 12.5 \mathrm{~Hz}, \mathrm{H}_{\mathrm{x}}-1\right), 3.32-3.31(1 \mathrm{H}, \mathrm{m}, \mathrm{H}-4 \mathrm{a})$, $3.02-3.00\left(1 \mathrm{H}, \mathrm{m}, \mathrm{CH}_{2}\right), 2.85-2.83\left(1 \mathrm{H}, \mathrm{m}, \mathrm{CH}_{2}\right), 2.72\left(1 \mathrm{H}, \mathrm{t}, J 11.5 \mathrm{~Hz}, \mathrm{H}_{\mathrm{y}}-1\right), 2.55-2.56$ $(1 \mathrm{H}, \mathrm{m}, \mathrm{H}-5), 1.69-1.59$ (2H, ovl. m, $\left.\mathrm{H}_{\mathrm{x}}-2,3\right), 1.45-1.39\left(1 \mathrm{H}, \mathrm{m}, \mathrm{H}_{\mathrm{y}}-2\right), 1.36-1.30(2 \mathrm{H}, \mathrm{m}$, $\left.\mathrm{H}_{\mathrm{y}}-3,4\right), 1.01-0.98$ (1H, m, $\left.\mathrm{H}_{\mathrm{x}}-4\right) ;{ }^{13} \mathrm{C}$ NMR: (150 MHz, dimethyl sulfoxide- $\left.d_{6}\right)$ : 145.8 (C-10a), 140.6 (C-1'), 130.3 (C-2', 6'), 129.2 (C-7), 128.2 (C-3', 5'), 128.2 (C-9), 126.9 (C-6a), 126.8 (C4'), 117.0 (C-8), 112.5 (C-10), 58.1 (C-4a), 47.6 (C-1), 45.0 (C-6), 40.3 (C-5), $37.9\left(\mathrm{CH}_{2}\right), 26.1$ (C-4), 25.1 (C-2), 24.7 (C-3). Anal. calcd. for $\mathrm{C}_{20} \mathrm{H}_{24} \mathrm{~N}_{2} \times 2 \mathrm{HCl}$ (365.33): C, 65.70\%; H, 7.12\%; N, 7.66\%. Found: C, 65.48\%; H, 7.19\%; N, 7.49\%. HRMS: (ESI+) $\mathrm{m} / z$ calcd. for $\mathrm{C}_{20} \mathrm{H}_{25} \mathrm{~N}_{2}$ $[\mathrm{M}+\mathrm{H}]^{+}$293.2012; found. 293.2002.

Biology. Rat SSAO activity was measured using the microsomal fraction of rat aorta purified by means of differential centrifugation. The enzymatic activity was measured in a fluorescent coupled reaction. SSAO oxidizes its substrates (benzylamine in $1 \mathrm{mM}$ concentration) to produce hydrogen 
peroxide which produces the oxidized form of Amplex ${ }^{\circledR}$ UltraRed (Invitrogen) that can be readily measured in a fluorimetric plate reader at Ex/Em 540/590 nm. Measurements were conducted in a 384-well format in the final volume of $40 \mu \mathrm{l}$. The tested products were incubated 10 minutes at room temperature with the enzyme, and then the substrate was added to initialize the reaction at $30{ }^{\circ} \mathrm{C}$. Fluorescence was read at one hour of reaction and corrected with the value read before substrate addition. Single concentration measurements were conducted at 100 and $10 \mu \mathrm{M}$ concentration of the compounds using duplicates. The dose response curves of the inhibitors were measured using at least 7 dilution points with 5-fold dilution steps. Duplicate points were determined for each concentration. $\mathrm{IC}_{50}$ values were calculated from the remaining activity, the graphs were fitted using Origin 5.0 software.

\section{Acknowledgments}

The authors thank Dr. Tamás Gáti, Sándor Boros and Dr. Dóra Bogdán for their contributions to the assignment of NMR spectra, Dr. Andrea Czompa for her help in the preparative work, TargetEx company for the biological measurements as well as Dr. Tamás Tábi for his evaluation of these data, and Prof. Imre Csizmadia for his valuable comments and revision of the manuscript.

\section{References}

1. Lyles, G. A. Int. J. Biochem. Cell Biol. 1996, 28, 259. http://dx.doi.org/10.1016/1357-2725(95)00130-1

2. Olivieri, A.; Rico, D.; Khiari, Z.; Henehan, G.; O’Sullivan, J.; Tipton, K. J. Neural Transm. 2011, 118, 1079.

http://dx.doi.org/10.1007/s00702-011-0611-z

3. Boyce, S.; Tipton, K. F.; O’Sullivan, M. I.; Davey, G. P.; Gildea, M. M.; McDonald, A. G.; Olivieri, A.; O'Sullivan, J. Copper amine oxidases structures, catalytic mechanisms and role in pathophysiology. CRC Press, Boca Raton, FL 2009, 5.

http://dx.doi.org/10.1201/9781420076813.ch2

4. Salmi, M.; Jalkanen, S. FEBS Lett 2011, 585, 1543.

http://dx.doi.org/10.1016/j.febslet.2011.04.033

5. Noda, K.; She, H.; Nakazawa, T.; Hisatomi, T.; Nakao, S.; Almulki, L.; Zandi, S.; Miyahara, S.; Ito, Y.; Thomas, K. L.; Garland, R. C.; Miller, J. W.; Gragoudas, E. S.; Mashima, Y.; Hafezi-Moghadam, A. FASEB J 2008, 22, 2928.

http://dx.doi.org/10.1096/fj.07-105346

6. Énzsöly, A.; Dunkel, P.; Récsán, Z.; Győrffy, H.; Tóth, J.; Marics, G.; Bori, Z.; Tóth, M.; Zelkó, R.; Paolo, M.; Mátyus, P.; Németh, J. J. Neural Transm. 2011, 118, 1065. http://dx.doi.org/10.1007/s00702-011-0595-8 
7. Énzsöly, A.; Marko, K.; Tábi, T.; Szökő, E.; Zelkó, R.; Tóth, M.; Petrash, J. M.; Mátyus, P.; Németh, J. J. Neural Transm. 2013, 120, 969. http://dx.doi.org/10.1007/s00702-013-0986-0

8. Watcharotayangul, J.; Mao, L.; Xu, H.; Vetri, F.; Baughman, V. L.; Paisansathan, C.; Pelligrino, D. A. J. Neurochem. 2012, 123 Suppl 2, 116. http://dx.doi.org/10.1111/j.1471-4159.2012.07950.x

9. Song, M. S.; Baker, G. B.; Dursun, S. M.; Todd, K. G. J. Neurochem. 2010, 114, 1405.

10. Xu, H. L.; Salter-Cid, L.; Linnik, M. D.; Wang, E. Y.; Paisansathan, C.; Pelligrino, D. A. J. Pharmacol. Exp. Ther. 2006, 317, 19. http://dx.doi.org/10.1124/jpet.105.096958

11. Mátyus, P., Magyar, K., Pihlavista, M., Gyires, K., Haider, N., Wang, Y., Woda, P., Dunkel, P., Tóth-Sarudy, É., Túrós, Gy., PCT Int. Appl. 029379, 2010; Chem. Abstr. 2010; 152, 358062.

12. Tábi, T.; Szökő, E.; Mérey, A.; Tóth, V.; Mátyus, P.; Gyires, K. J. Neural. Transm. 2013, $120,963$. http://dx.doi.org/10.1007/s00702-012-0961-1

13. Foot, J. S.; Yow, T. T.; Schilter, H.; Buson, A.; Deodhar, M.; Findlay, A. D.; Guo, L.; McDonald, I. A.; Turner, C. I.; Zhou, W.; Jarolimek, W. J. Pharmacol. Exp. Ther. 2013, 347, 365. http://dx.doi.org/10.1124/jpet.113.207613

14. Schilter, H. C.; Collison, A.; Russo, R. C.; Foot, J. S.; Yow, T. T.; Vieira, A. T.; Tavares, L. D.; Mattes, J.; Teixeira, M. M.; Jarolimek, W. Respir. Res. 2015, 16, 1. http://dx.doi.org/10.1186/s12931-015-0200-Z

15. Mercader, J.; Iffiú-Soltesz, Z.; Brenachot, X.; Földi, Á.; Dunkel, P.; Balogh, B.; Attané, C.; Valet, P.; Mátyus, P.; Carpéné, C. Future Med. Chem. 2010, 2, 1735. http://dx.doi.org/10.4155/fmc.10.260

16. Dunkel, P.; Balogh, B.; Meleddu, R.; Maccioni, E.; Gyires, K.; Mátyus, P. Expert Opin. Ther. Pat. 2011, 21, 1453.

17. Solé, M.; Miñano-Molina, A. J.; Unzeta, M. Neurobiol. Aging 2015, 36, 762. http://dx.doi.org/10.1016/j.neurobiolaging.2014.09.030

18. Tamásikné, H. Z.; Dezső-Tekus, V.; Scheich, B.; Mátyus, P. WO 2015159112 A1.

19. Karim, S.; Liaskou, E.; Fear, J.; Garg, A.; Reynolds, G.; Claridge, L.; Adams, D. H.; Newsome, P. N.; Lalor, P. F. Am. J. Physiol. Gastrointest. Liver Physiol. 2014, 307, G1180. http://dx.doi.org/10.1152/ajpgi.00377.2013

20. Pannecoeck, R.; Serruys, D.; Benmeridja, L.; Delanghe, J. R.; Geel, N. v.; Speeckaert, R.; Speeckaert, M. M. Crit. Rev. Clin. Lab. Sci. 2015, 52, 284. http://dx.doi.org/10.3109/10408363.2015.1050714

21. Sun, P.; Solé, M.; Unzeta, M. Cerebrovasc. Dis. 2014, 37, 171. http://dx.doi.org/10.1159/000357660

22. Januszewski, A. S.; Mason, N.; Karschimkus, C. S.; Rowley, K. G.; Best, J. D.; O’Neal, D. 
N.; Jenkins, A. J. Diab. Vasc. Dis. Res. 2014, 11, 262.

http://dx.doi.org/10.1177/1479164114532963

23. Payrits, M.; Sághy, É.; Mátyus, P.; Czompa, A.; Ludmerczki, R.; Deme, R.; Sándor, Z.; Helyes, Z.; Szőke, É. Neuroscience 2016, 324, 151.

http://dx.doi.org/10.1016/j.neuroscience.2016.02.049

24. Shepard, E. M.; Dooley, D. M. Acc. Chem. Res. 2015, 48, 1218.

http://dx.doi.org/10.1021/ar500460z

25. Bligt-Lindén, E.; Pihlavisto, M.; Szatmári, I.; Otwinowski, Z.; Smith, D. J.; Lázár, L.; Fülöp, F.; Salminen, T. A. J. Med. Chem. 2013, 56, 9837.

http://dx.doi.org/10.1021/jm401372d

26. Olivieri, A.; Tipton, K.; O'Sullivan, J. J. Neural Transm. 2007, 114, 747.

http://dx.doi.org/10.1007/s00702-007-0682-z

27. O'Sullivan, J.; Davey, G.; O'Sullivan, M.; Tipton, K. F. J. Neural Transm. 2007, 114, 751. http://dx.doi.org/10.1007/s00702-007-0683-y

28. Meth-Cohn, O.; Suschitzky, H. Heterocycles by Ring Closure of Ortho-Substituted t-Anilines (The t-Amino Effect); Academic Press, 1972; Vol. 14, pp 211-278. http://dx.doi.org/10.1016/s0065-2725(08)60954-x

29. Meth-Cohn, O. Adv. Heterocycl. Chem. 1996, 65, 1. http://dx.doi.org/10.1016/S0065-2725(08)60294-9

30. Quintela, J. M. Recent Res. Dev. Org. Chem. 2003, 7, 259.

31. Nijhuis, W. H. N.; Verboom, W.; Reinhoudt, D. N.; Harkema, S. J. Am. Chem. Soc. 1987, $109,3136$. http://dx.doi.org/10.1021/ja00244a041

32. Groenen, L. C.; Verboom, W.; Nijhuis, W. H. N.; Reinhoudt, D. N.; Van Hummel, G. J.; Feil, D. Tetrahedron 1988, 44, 4637. http://dx.doi.org/10.1016/S0040-4020(01)86166-4

33. Nijhuis, W. H. N.; Verboom, W.; Abuelfadl, A.; Harkema, S.; Reinhoudt, D. N. J. Org. Chem. 1989, 54, 199. http://dx.doi.org/10.1021/jo00262a043

34. Nijhuis, W. H. N.; Verboom, W.; Abuelfadl, A.; Vanhummel, G. J.; Reinhoudt, D. N. J. Org. Chem. 1989, 54, 209. http://dx.doi.org/10.1021/jo00262a044

35. Kelderman, E.; Noorlander-Bunt, H. G.; Verboom, W.; Reinhoudt, D. N.; van Eerden, J. Recl. Trav. Chim. Pays-Bas 1991, 110, 115. http://dx.doi.org/10.1002/recl.19911100405

36. Mátyus, P.; Éliás, O.; Tapolcsányi, P.; Polonka-Bálint, Á.; Halász-Dajka, B. Synthesis 2006, 2006, 2625.

37. Murarka, S.; Deb, I.; Zhang, C.; Seidel, D. J. Am. Chem. Soc. 2009, 131, 13226. http://dx.doi.org/10.1021/ja905213f

38. Cao, W.; Liu, X.; Wang, W.; Lin, L.; Feng, X. Org. Lett. 2011, 13, 600. 
http://dx.doi.org/10.1021/ol1028282

39. Zhou, G.; Liu, F.; Zhang, J. Chem. Eur. J. 2011, 17, 3101. http://dx.doi.org/10.1002/chem.201100019

40. Kang, Y. K.; Kim, S. M.; Kim, D. Y. J. Am. Chem. Soc. 2010, 132, 11847. http://dx.doi.org/10.1021/ja103786c

41. Mori, K.; Ehara, K.; Kurihara, K.; Akiyama, T. J. Am. Chem. Soc. 2011, 133, 6166. http://dx.doi.org/10.1021/ja2014955

42. Mori, K.; Ohshima, Y.; Ehara, K.; Akiyama, T. Chem. Lett. 2009, $38,524$. http://dx.doi.org/10.1246/c1.2009.524

43. Murarka, S.; Zhang, C.; Konieczynska, M. D.; Seidel, D. Organic Letters 2009, 11, 129. http://dx.doi.org/10.1021/o1802519r

44. Krasnov, K. A.; Khrustalev, V. N. Cryst. Growth Des. 2014, 14, 3975. http://dx.doi.org/10.1021/cg500570u

45. Tóth, L.; Fu, Y.; Zhang, H. Y.; Mándi, A.; Kövér, K. E.; Illyes, T. Z.; Kiss-Szikszai, A.; Balogh, B.; Kurtán, T.; Antus, S.; Mátyus, P. Beilstein J Org Chem 2014, 10, 2594. http://dx.doi.org/10.3762/bjoc.10.272

46. Kaval, N.; Dehaen, W.; Matyus, P.; Van der Eycken, E. Green Chem. 2004, 6, 125. http://dx.doi.org/10.1039/B316882D

47. Kaval, N.; Halasz-Dajka, B.; Vo-Thanh, G.; Dehaen, W.; Van der Eycken, J.; Mátyus, P.; Loupy, A.; Van der Eycken, E. Tetrahedron 2005, 61, 9052. http://dx.doi.org/10.1016/j.tet.2005.07.046

48. Platonova, A. Y.; Poluikova, A. A.; Trofimova, O. A.; Glukhareva, T. V.; Morzherin, Y. Y. Chem. of Heterocycl. Compd. 2014, 50, 1450. http://dx.doi.org/10.1007/s10593-014-1609-x

49. Platonova, A. Y.; Poluikova, A. A.; Trofimova, O. A.; Glukhareva, T. V.; Morzherin, Y. Y. Chem Heterocycl Compd 2014, 50, 1450. http://dx.doi.org/10.1007/s10593-014-1609-x

50. Curran, D. P.; Seong, C. M. Synlett 1991, 1991, 107.

51. Gerlach, U. Tetrahedron Lett. 1995, 36, 5159. http://dx.doi.org/10.1016/00404-0399(50)10064-

52. Caddick, S.; Judd, D. B.; Lewis, A. K. d. K.; Reich, M. T.; Williams, M. R. V. Tetrahedron 2003, 59, 5417 . http://dx.doi.org/10.1016/S0040-4020(03)00858-5

53. Károlyházy, L.; Regdon, G.; Éliás, O.; Beke, G.; Tábi, T.; Hódi, K.; Erős, I.; Mátyus, P. J. Mol. Struct.: THEOCHEM 2003, 666-667, 667. http://dx.doi.org/10.1016/j.theochem.2003.08.090

54. Yraola, F.; García-Vicente, S.; Fernández-Recio, J.; Albericio, F.; Zorzano, A.; Marti, L.; Royo, M. J. Med. Chem. 2006, 49, 6197. http://dx.doi.org/10.1021/jm051076e 
55. Kinemuchi, H.; Sugimoto, H.; Obata, T.; Satoh, N.; Ueda, S. NeuroToxicology 2004, 25, 325. http://dx.doi.org/10.1016/S0161-813X(03)00118-9

56. Möhrle, H.; Gerloff, J. Arch. Pharm. 1979, 312, 219. http://dx.doi.org/10.1002/ardp.19793120308

57. Dubrovskiy, A. V.; Larock, R. C. Org. Lett. 2011, 13, 4136. http://dx.doi.org/10.1021/ol2016803

58. Verboom, W.; Hamzink, M. R. J.; Reinhoudt, D. N.; Visser, R. Tetrahedron Lett. 1984, 25, 4309.

http://dx.doi.org/10.1016/S0040-4039(01)81425-8 